\title{
مباحث \\ في \\ الخبر المتواتر
}

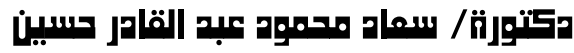

الأستاذ المساعد بقسم الحديث وعلومهه

كلية الار اسات الإسلامية و العربية- جامعة الأزهر

فرع البنات بالقاهرة

\section{المقدمة}

إن الحمد لله نحمده ونستعينه ونستغفره، ونعوذ بالله من شرور أنفسنا وسيئات

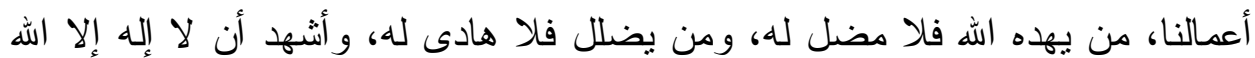

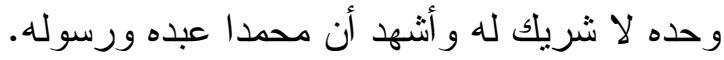

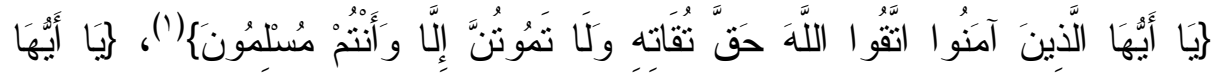

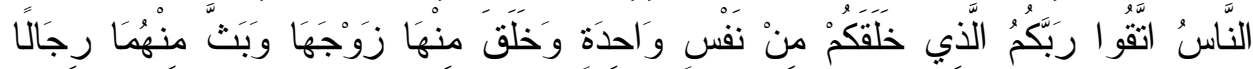

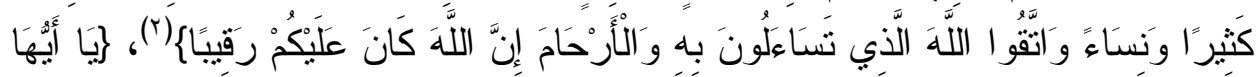

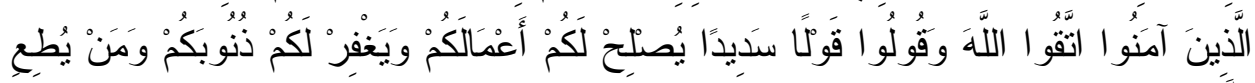

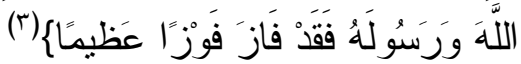
(أما بعد) فإن علم الحديث الشريف بعد القرآن الكريم هو أفضل العلوم وأعلاها و أجل المعارف وأسناها، إذ به يعلم مر اد الله سبحانه وتعالى من كلامه في كتابه

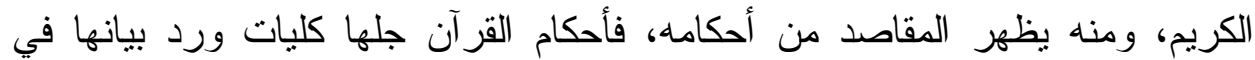

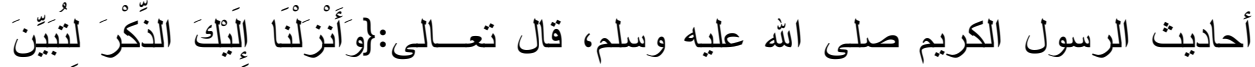

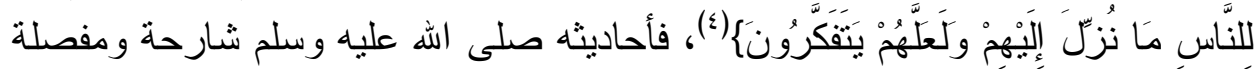

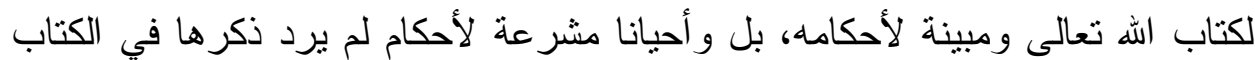

$$
\begin{aligned}
& \text { (1) سورة آل عمران: آية r • 1. }
\end{aligned}
$$

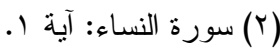

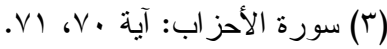

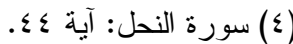


الكريم؛ فالحديث صنو القرآن، والأصل الثاني من أصول التشريع بعده، وها هي الآيات القر آنية و الأحاديث النبوية جاءت صريحة قاطعة بوجوب انباع حكم الرسول

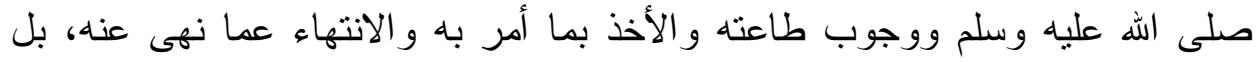

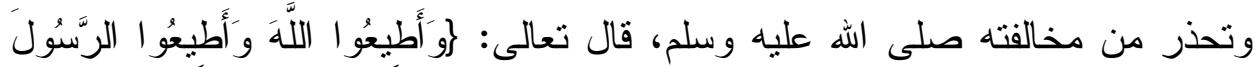

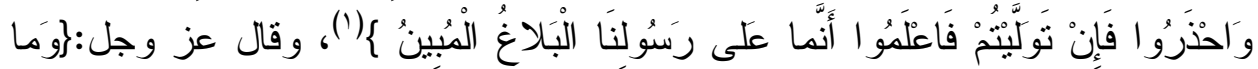

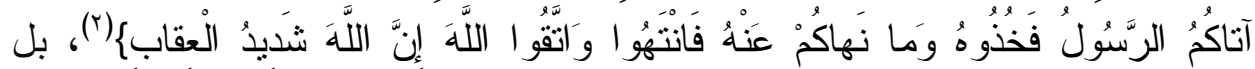

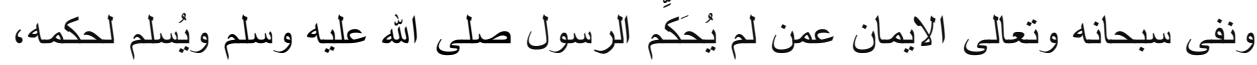

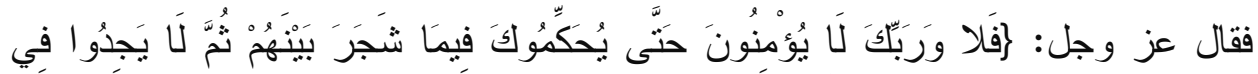

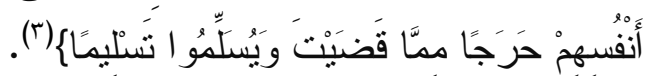

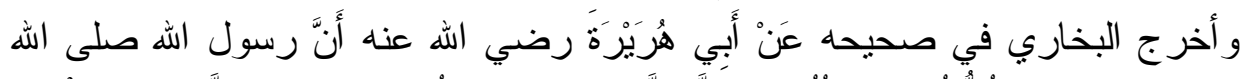

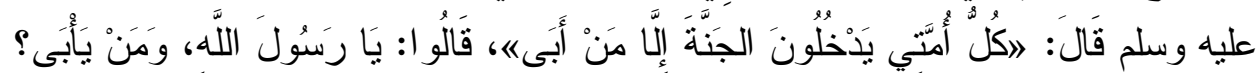

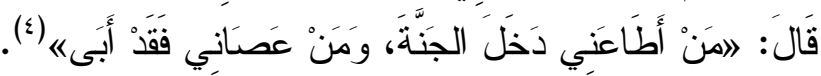

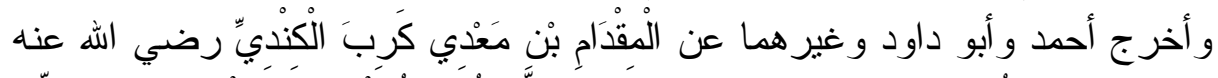

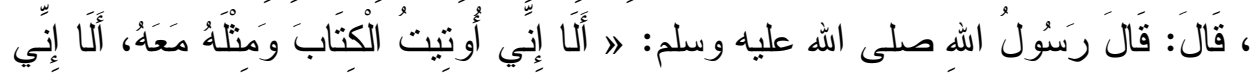

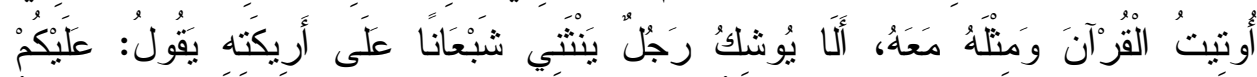

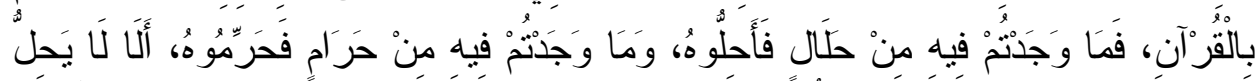

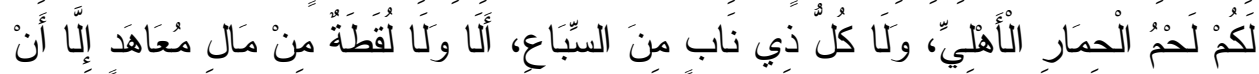

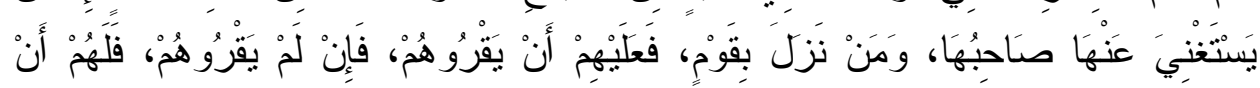

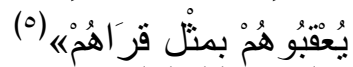

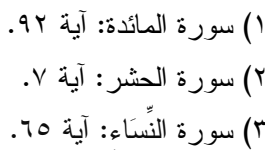

(§) اخرجه البخاري في صحيحه، كتاب: كتاب الاعتصام بالكتاب و السنة، باب الاقتداء بسنن رسول الله صلى الله عليه وسلم .VYA.Z،

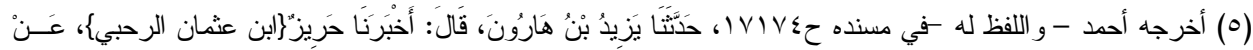

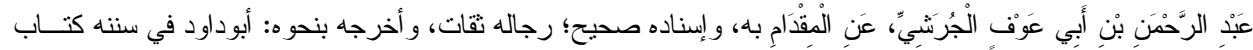

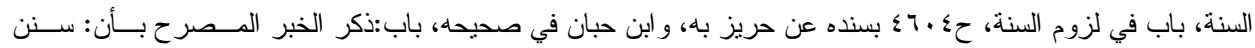

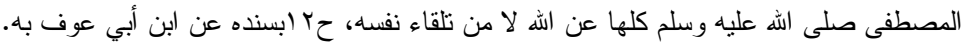


وقد حث صلى الله عليه وسلم على سماع حديثه الثريف، وتحمله، وتبليغه، فقي

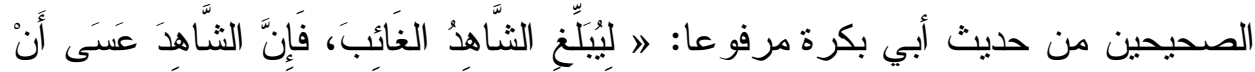

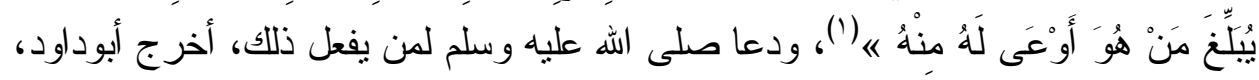

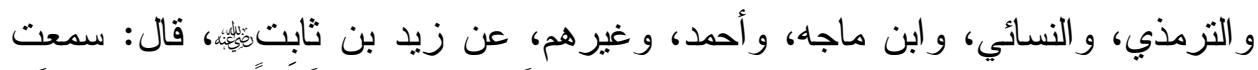

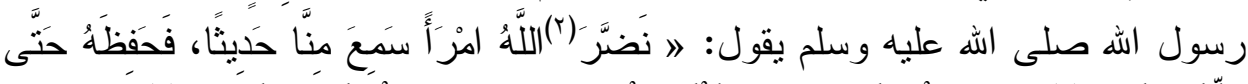

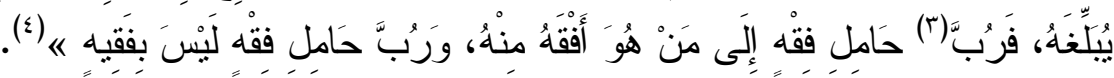

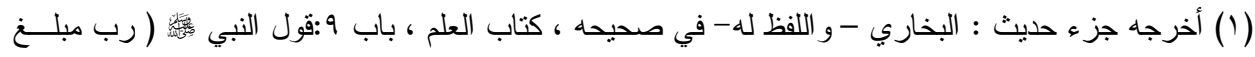

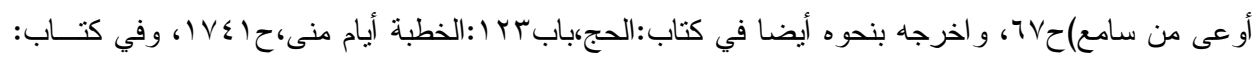

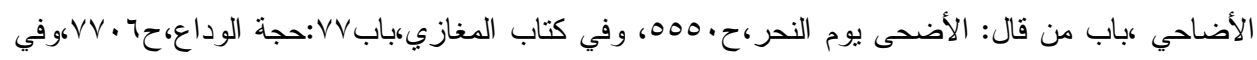

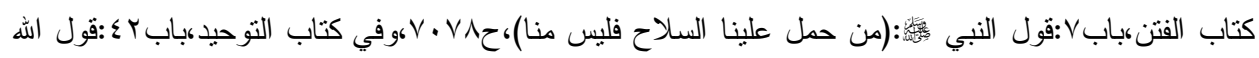

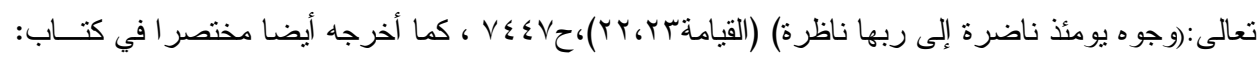

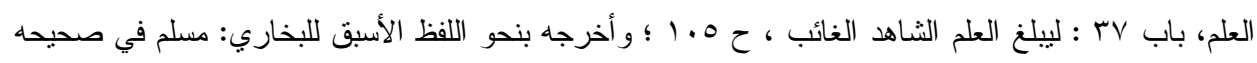

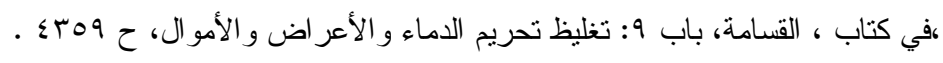

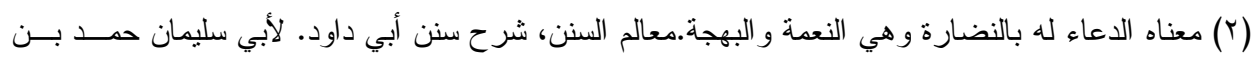

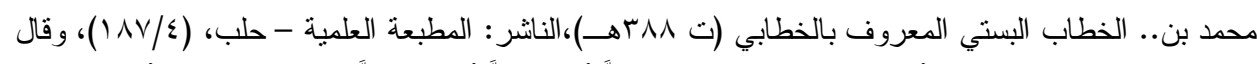

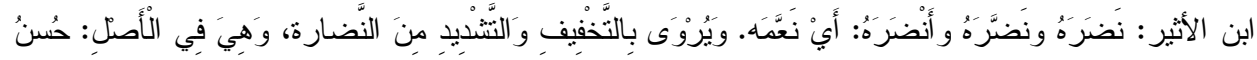

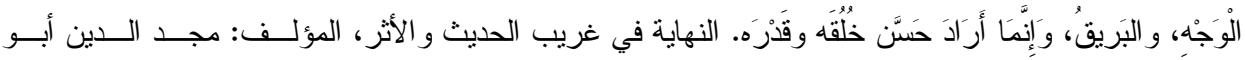

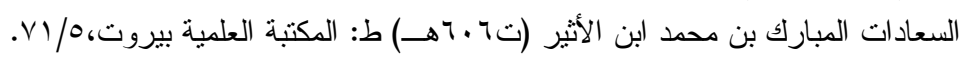

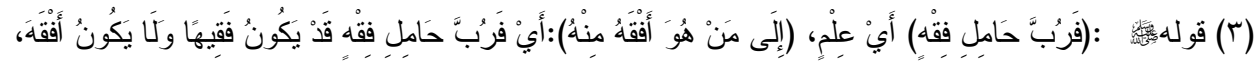

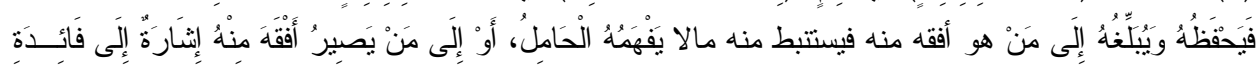

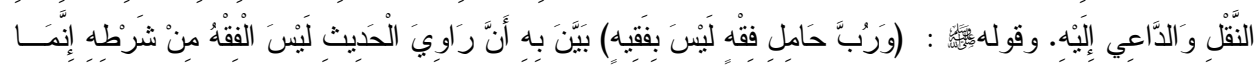

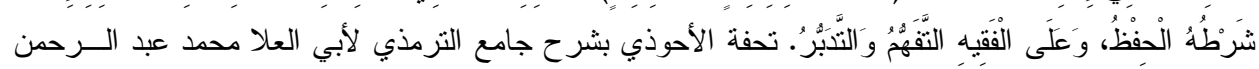

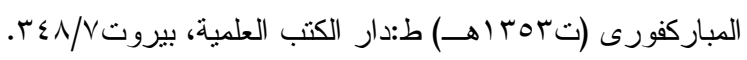

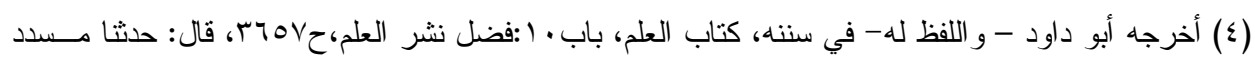

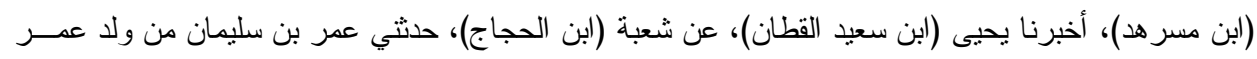

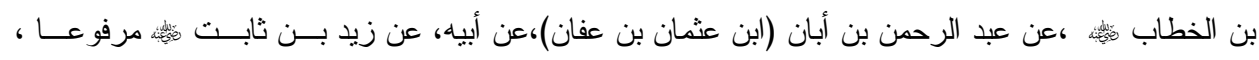

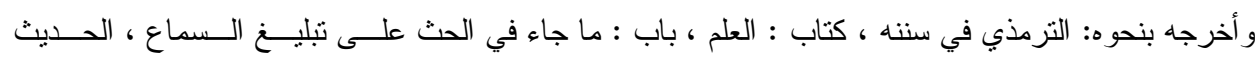

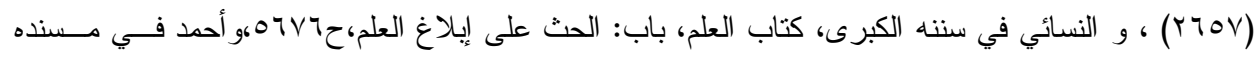

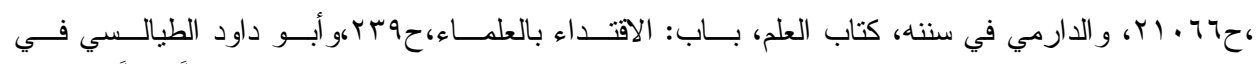

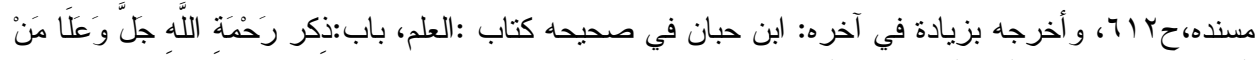

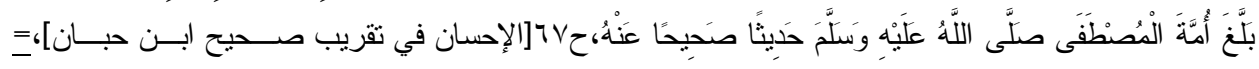




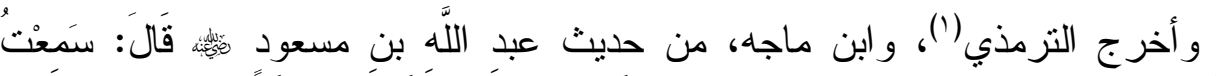

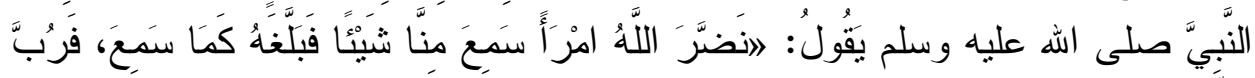

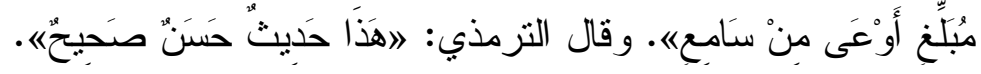
فلما كان شأن السنة كذللك؛ قيض الله تعالى لها في كل قرن من القرون منذ عهد الرسول صلى الله عليه وسلم رجالا عدو لا شرفهم بحملها وتبلغيها و المحافظة عليها،

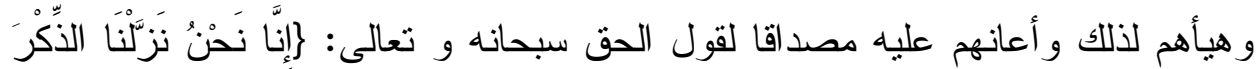

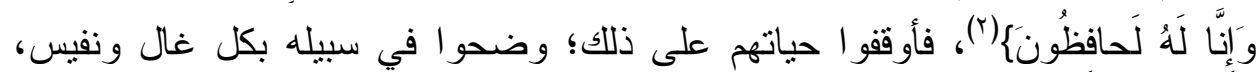
فقامو إنى طلب الأحاديث، فجمعوها، وكتبو ها بأسانيدها، و عرفو ا برجالها، وميزوا

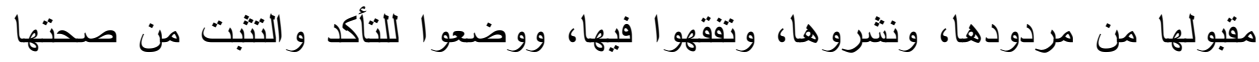

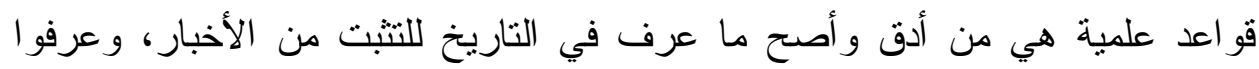

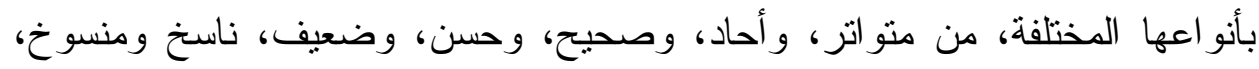

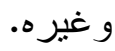

وفي هذا البحث سأتحدث عن نوع من أنواع هذه الأخبار ، وهو الخبر المتواتر؛

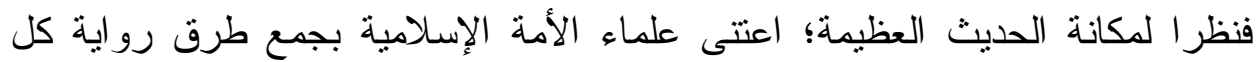

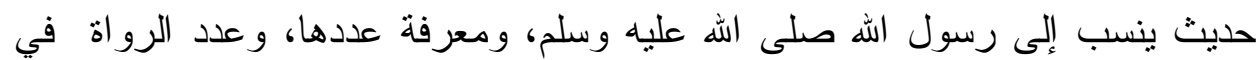

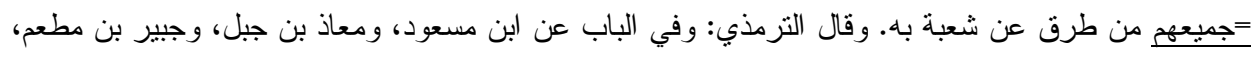

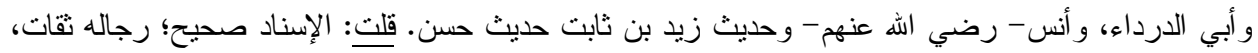

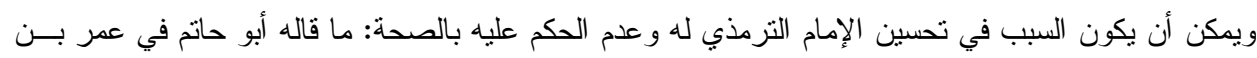

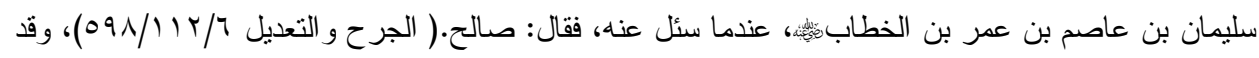

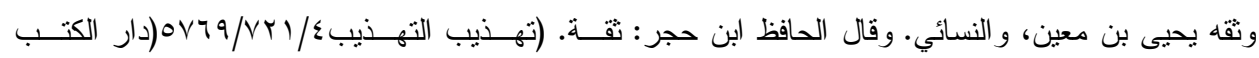

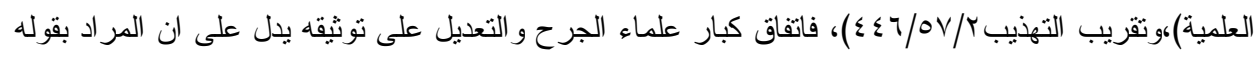

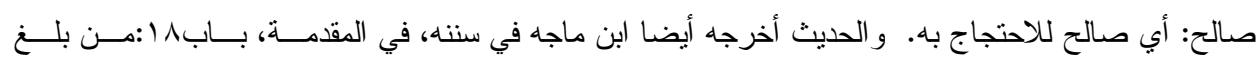

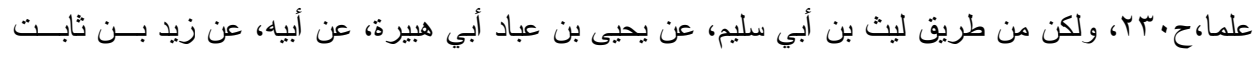

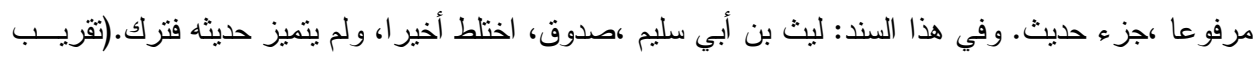

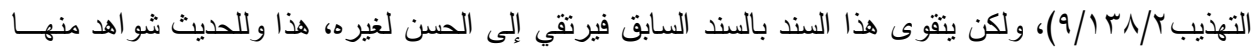
الحديث الذي يليه عن عبداله بن مسعود رضي الله عنه.

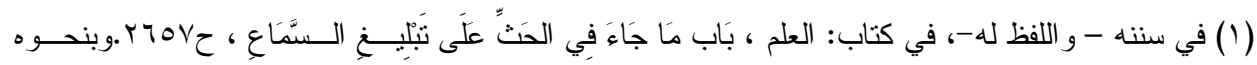

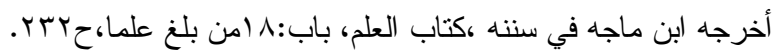


كل طبقة من طبقات السند، و أحوال هؤلاء الرواة؛ لما في ذللك من فو ائد جليلة على

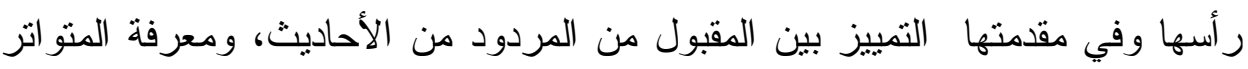

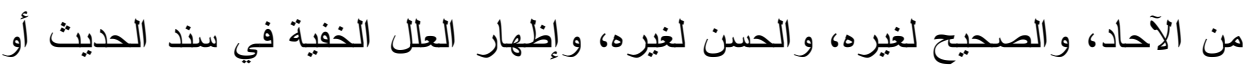

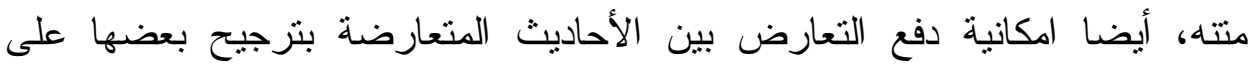

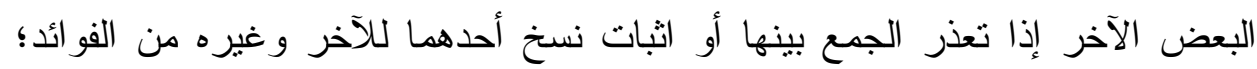

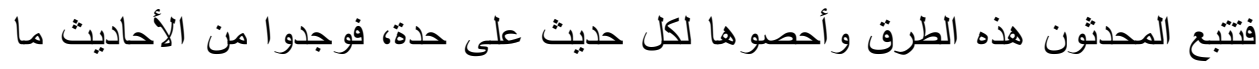

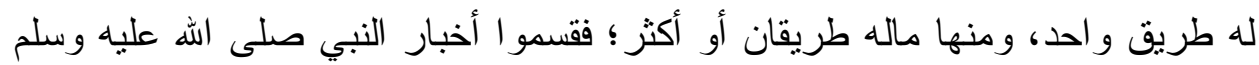
باعتبار كثزة عدد طرق روايته أو قلتها في كل طبقة من طبقات السند إلى قهن فمين:

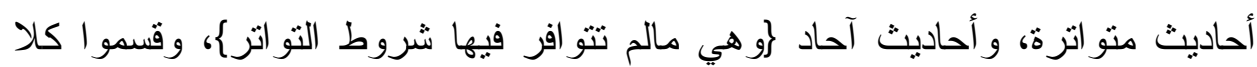

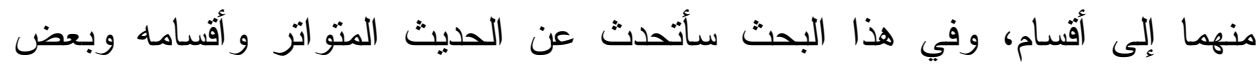
الأحكام المتعلقة به؛ ومما رغبني في الكتابة في هذا الموضوع وفي أن الكثير ممن كتب فيه

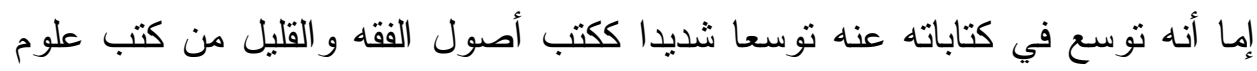
الحديث، أو اختصر في كتاباته عنه اختصار ا شديدا كمعظم كتب علوم الحديث؛ فأردت

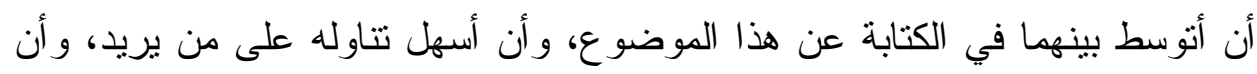

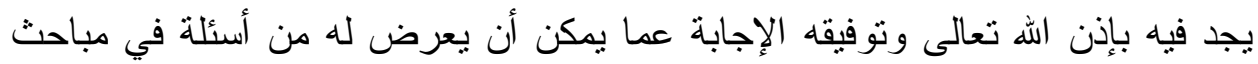

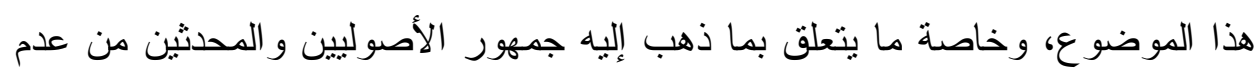

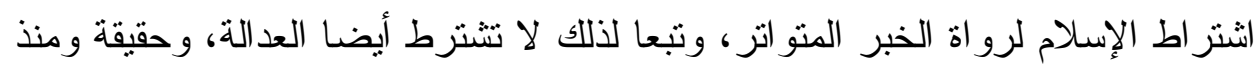

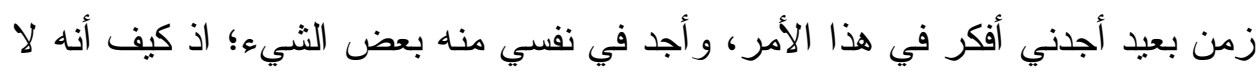

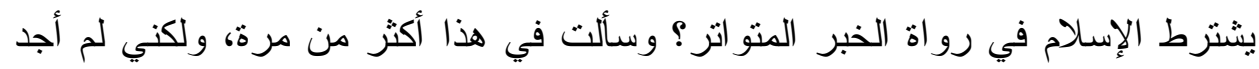

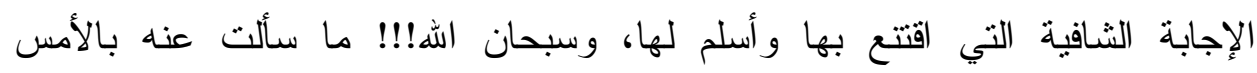
و استفسرت عنه كثير ا وأنا طالبة سؤلت عنه من إحدى طالباتي النجيبات بكلية

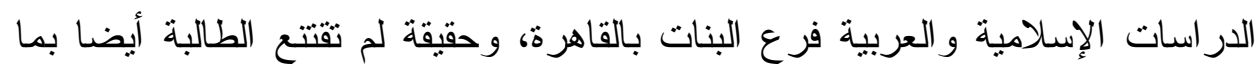

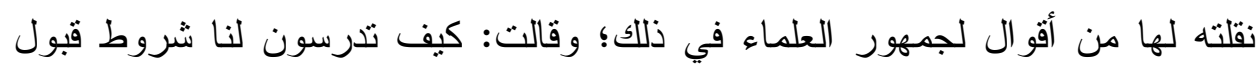
الر اوي وشروط قبول الحديث ثم بعد ذلك تقولون لنا عن أصح الأحاديث وهو هو المتو اتر لا يشترط فيه ذلك؟ قلت: تصح بجموع طرقها وليس بأفر ادها، قالت: وهل يكون

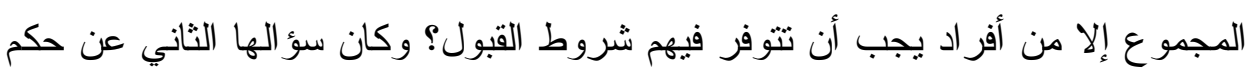

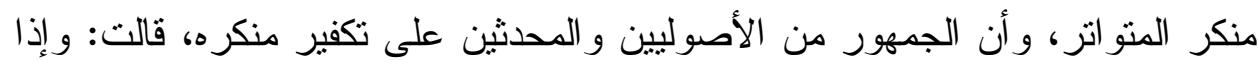


كان الأمر كما تقدم ولا يشترط في رواته العدالة، فكيف نكفر من لم يصدق بخبر غير

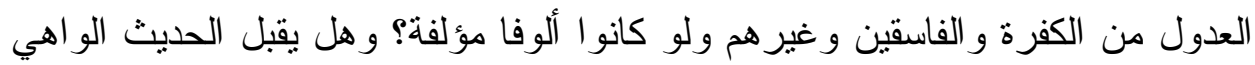
مهما تعددت طرقه؟ ولهذا رغبت أن أثنارك بجهدي المتو اضع في مناقنتة هذه المباحث في الخبر المتواتز، وأن أحاول بقدر استطاعتي وبعد الاطلاع الدقيق و القر اءة المتأنية

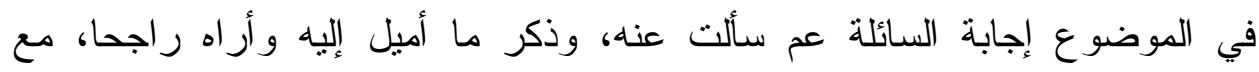
الحرص على الإيجاز وعدم التطويل بقدر الإمكان، وذكر أقو ال الحفاظ من المحدثين

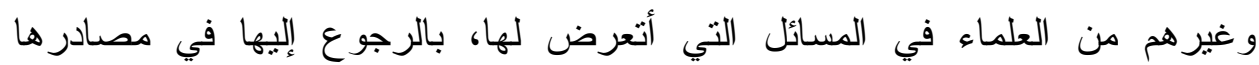

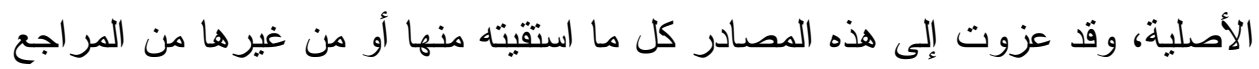

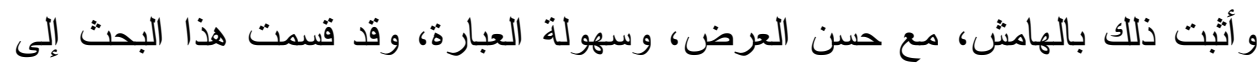

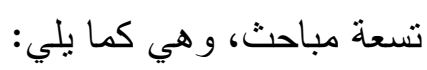

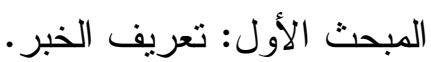

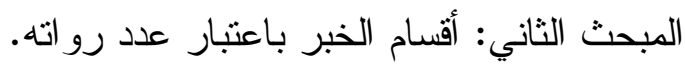
المبحث الثالث: تعريف الخبر المتو اتر . المبحث الر ابع: شروط الخبر ليصبح منو اتر ا. المبحث الخامس: أقسام الخبر المنو اتر . المبحث الساد: اختلاف العلماء في وجود الخبر المتواتر .

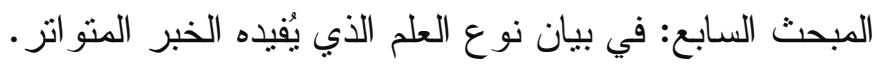

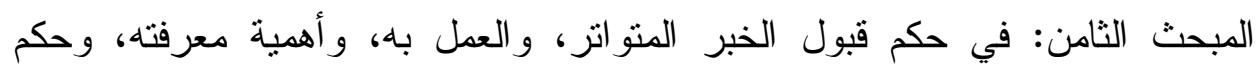
منكر المبحث التاسع: في الثبه الواردة على المنو اتز وردها. الخاتمة.

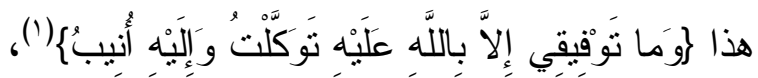

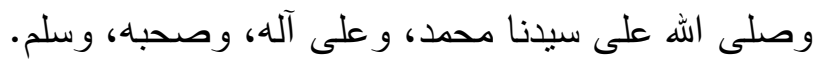




\section{المبحث الأول \\ تعريف الخبر}

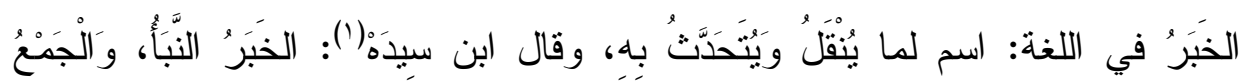

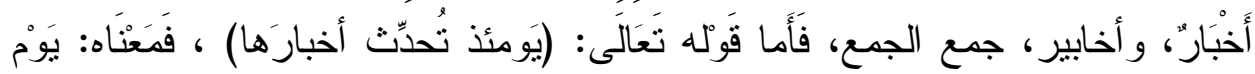

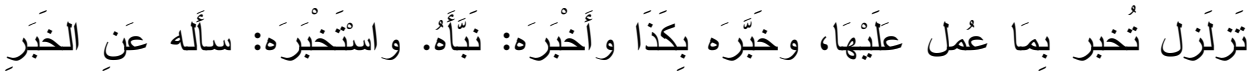

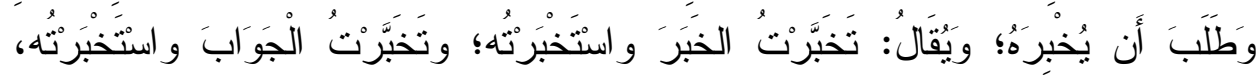

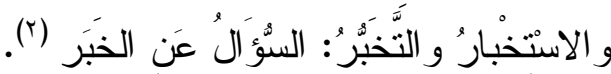
وفي اصطلاح الأصوليين(ّ): هو كل كلام يحتمل الصدق أو الكذب على سواء باعتبار ذاته، ويتطلب التصديق، وهو: باعتبار من ينسب إليه قد يعلم صدقه قطعا

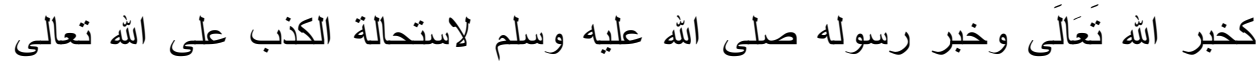
و عصمة رسوله صلى الله عليه وسلم، وقَد يعلم كذب الخبر قطعا كالخبر المُخَالف لخبر الله تعالى وخبر رسوله صلى الله عليه وسلم. وباعتبار حال رواته ونقلته قد يزيد احتمال الصدق فيه على احتمال الكذب كما إذا كان ونه

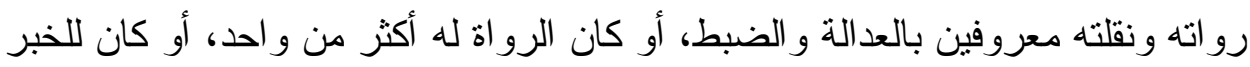

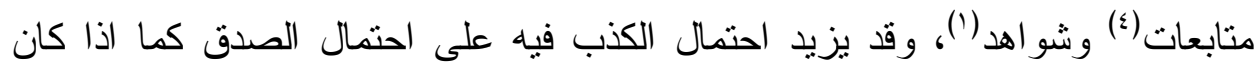

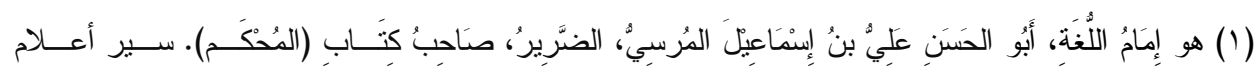

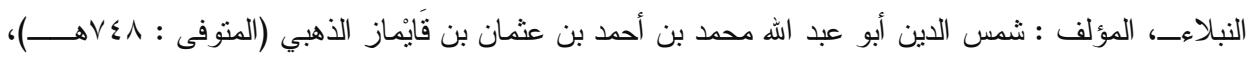

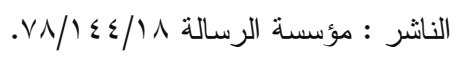

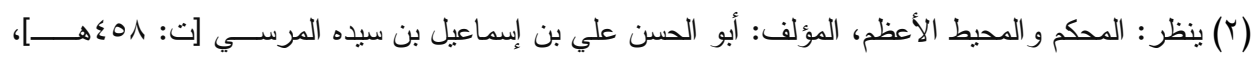

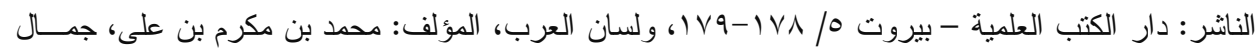

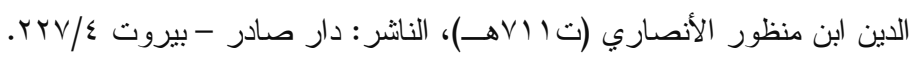

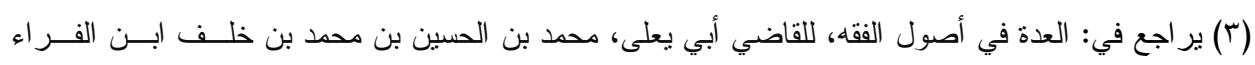

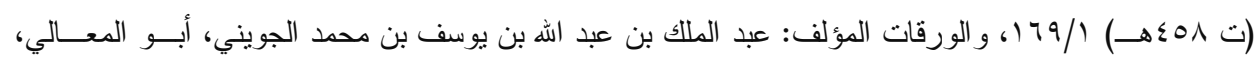

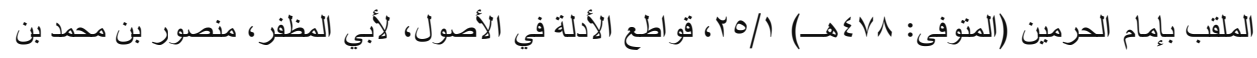

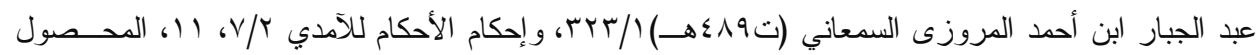

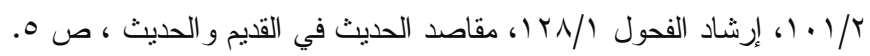

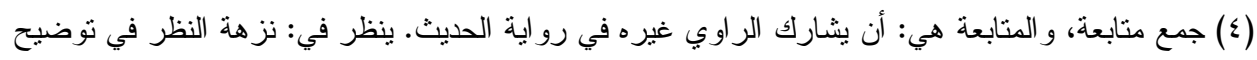

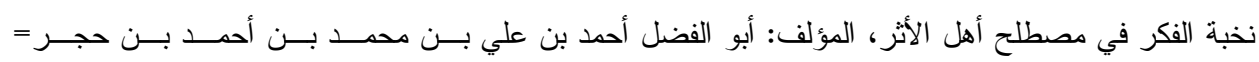


الرواة مضعفين أو مجهولين، أو كان الر اوي واحدا وليس أهلا لقبول تقرده، وليس لله

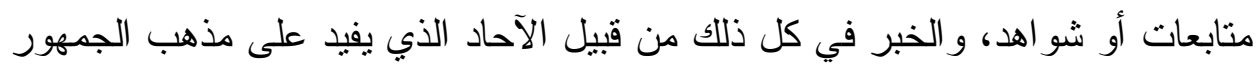
الظن عند سامعه، وقد يفيد العلم و اليقين عندما تكون رواته قد كثرت بحيث يحيل العقل

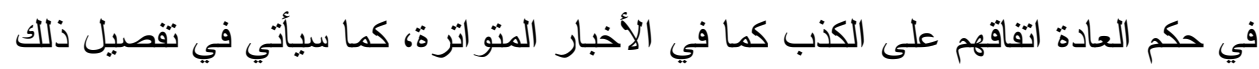

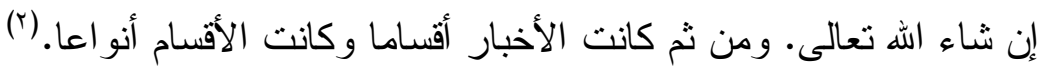

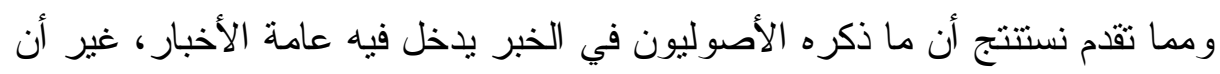

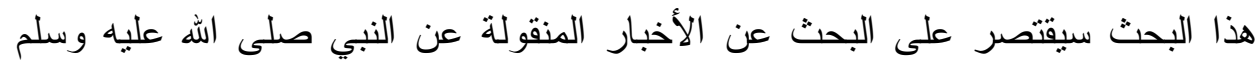

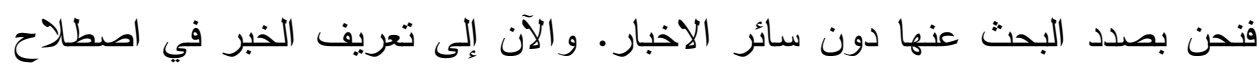
المحدثين:

للمحدثين في تعريف الخبر ثثلاثة أقو ال:

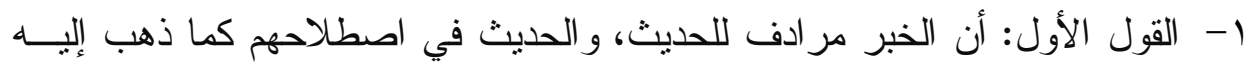

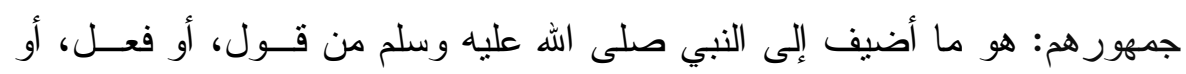

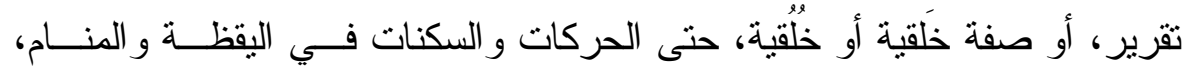

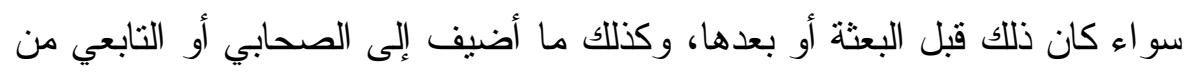

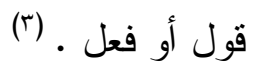

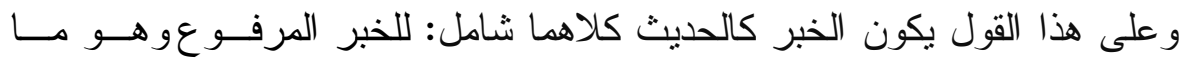

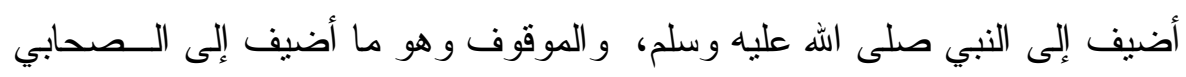

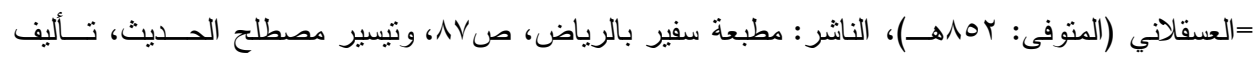

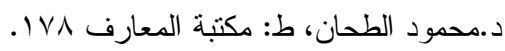

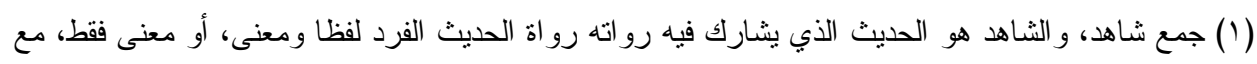

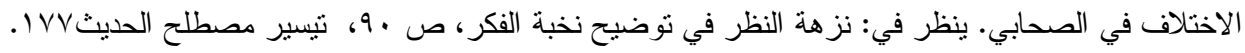

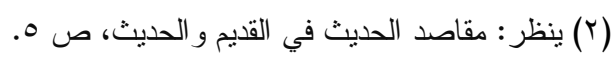

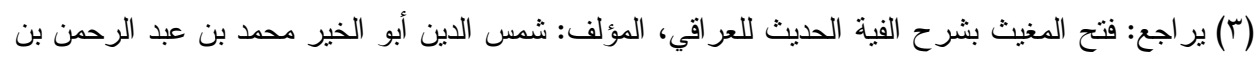

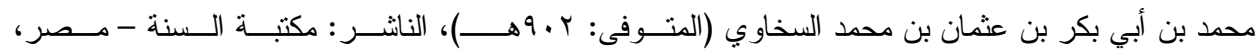

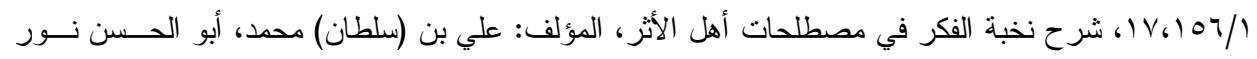

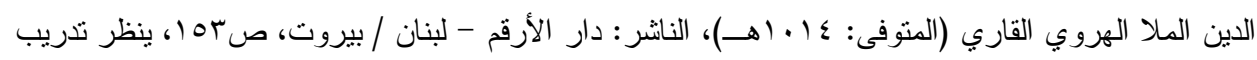

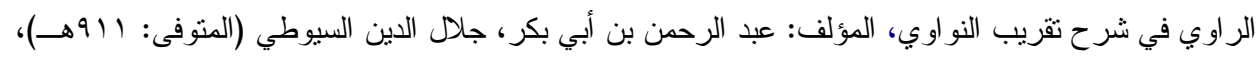


رضي الله عنه، و المقطوع وهو ما أضيف إلى التابعي، وهذا القول رجحه الحافظ

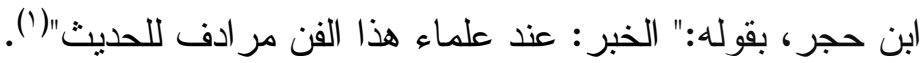

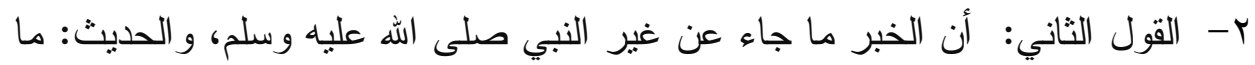

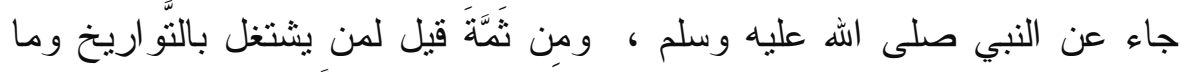

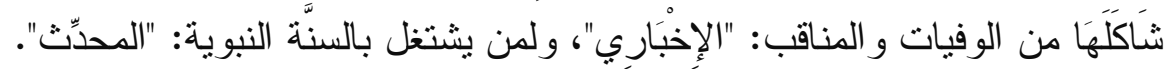

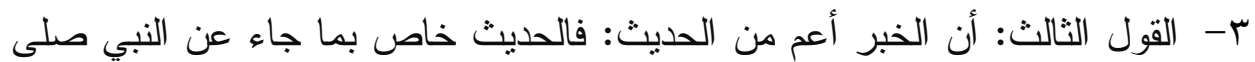
الله عليه وسلم، والخبر يشمل ما جاء عن النبي صلى الله عليه وسلم وعن الصحابة و التابعين ومن بعدهم، فكل حديث خبر و لا عكس، فعلى هذا يكون بينهما عموم وخصوص مطلق(r)، يتجمعان وينفرد الأعم منهما.

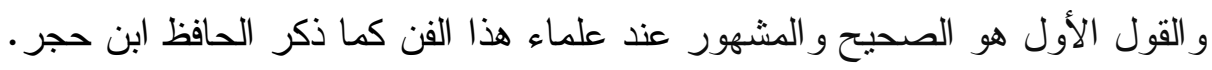

\section{المبحث الثاني}

\section{أقسام الخبر باعتبار عدد رواته}

الخبر عند المحدثين لله تقسيمات عدة باعتبارات متعددة، فهو ينقسم باعتبار من

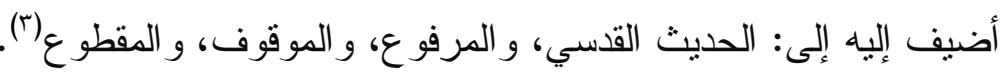

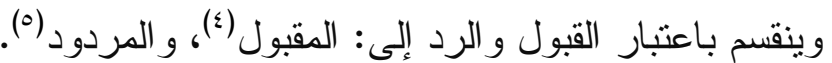

وباعتبار عدد الرواة الذين نقلوه ووصل الينا طريقهم في كل طبقة من طبقات الإن السناد - طبقة الصحابة الذين تحملوا عن الرسول صلى الله عليه وسلم وأدوا إلى التابعين،

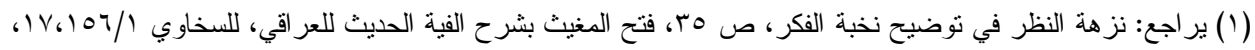

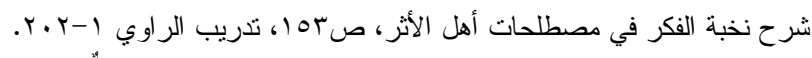

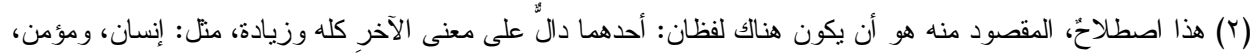

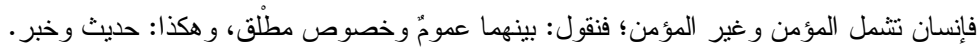

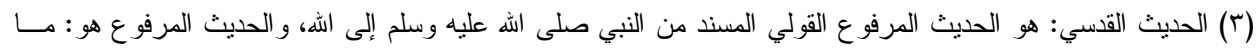

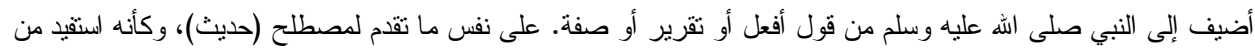

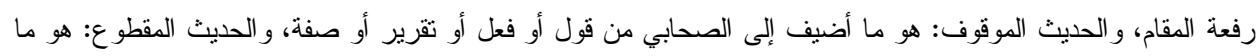

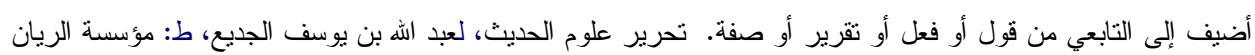

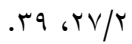

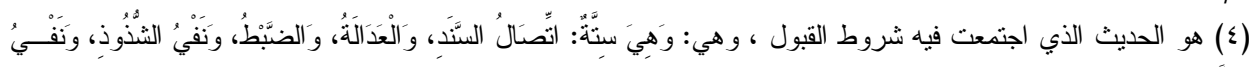

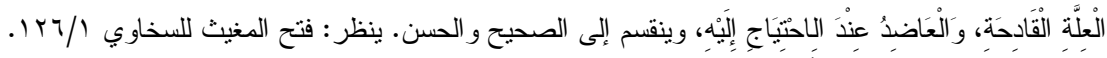

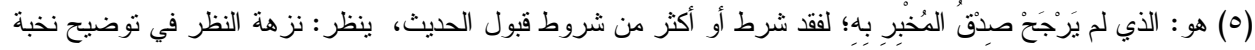

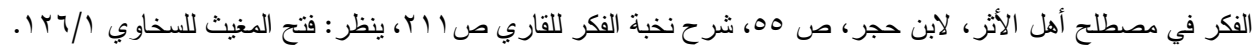


وطبقة التابعين الذنين تحملوا عن الصحابة رضي الله عنهم وأدوا إلى انباع التابعين،

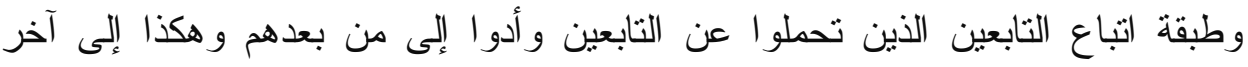

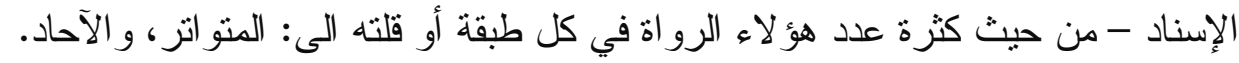

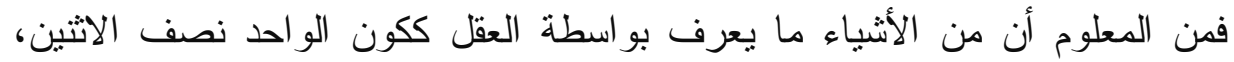

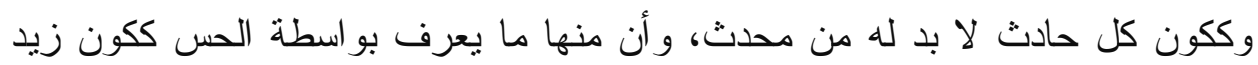

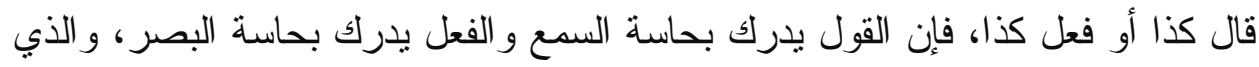

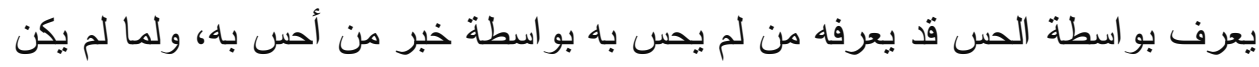

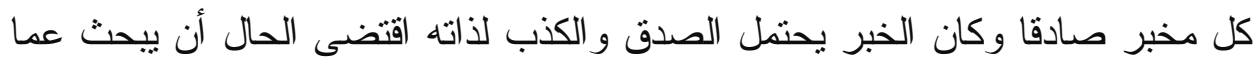

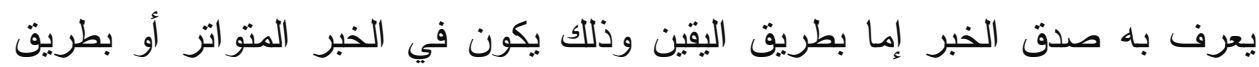

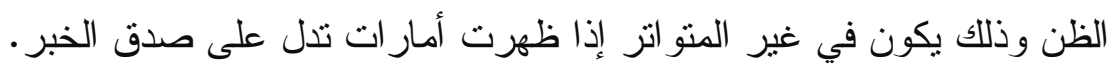

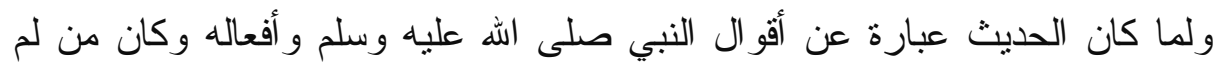

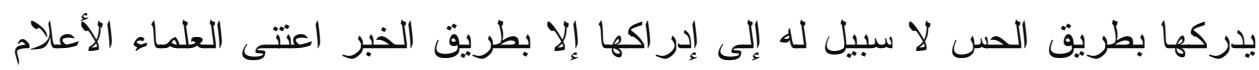

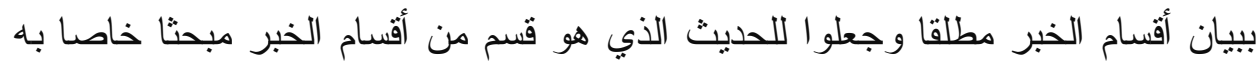

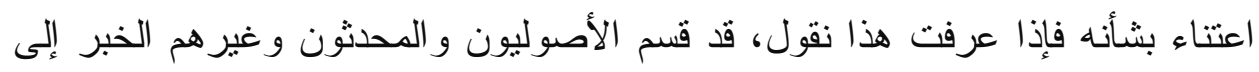

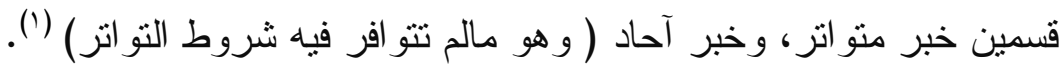

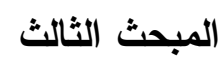

تعريف الخبر المتو اتر

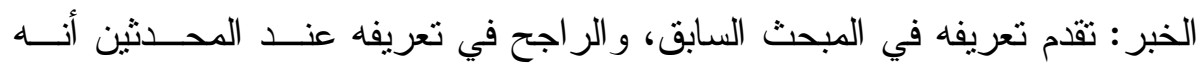

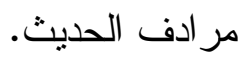

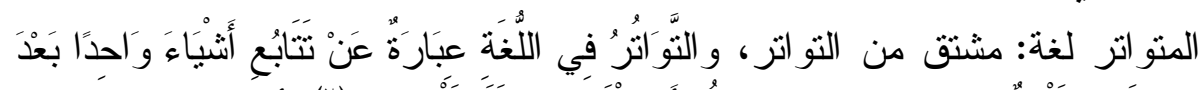

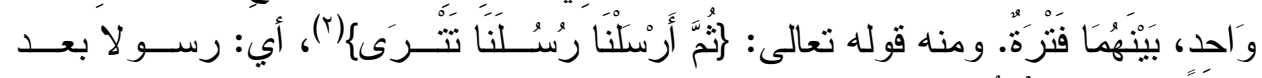
رسولَ، بينهما فَتَّرَة.

( (1) ينظر : توجيه النظر إلى أصول الأثر ، المؤلف: طاهر بن صالح (أو محمد صالح) ابن أحمد بن موهب، السمعوني الجزائري، ثم الدمـشقيّ

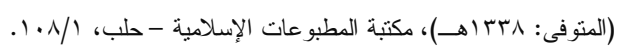

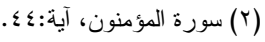

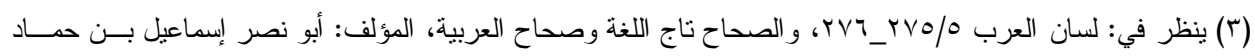

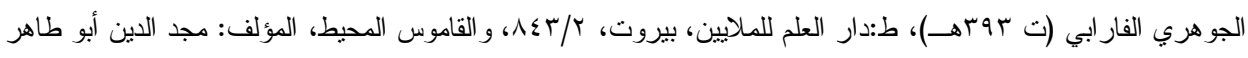

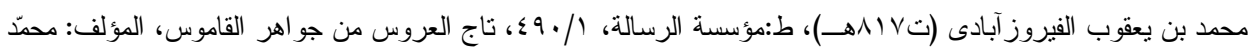

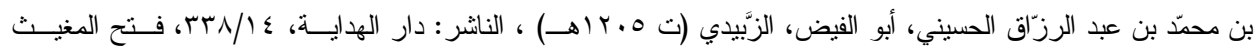


أما عن تعريف المتواتر في الاصطلاح، فسأذكر أو لا تعريفه في اصطلاح الأصــوليين (باعتبار أنهم أول من تحدث عنه)، ثم في اصطلاح المحدثين: ا - تعريف المتواتر في اصطلاح الأصوليين:

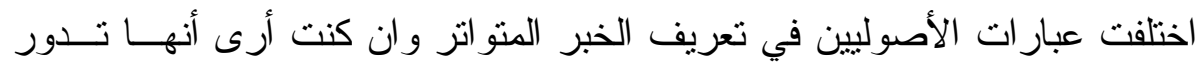
حول معنى و احد؛ فقد عرفه:

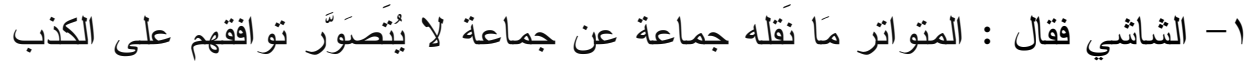

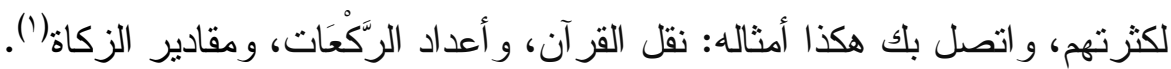

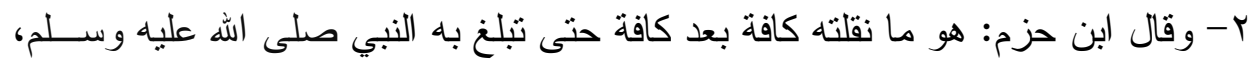

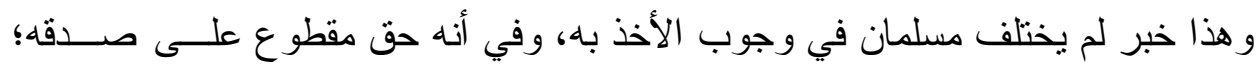

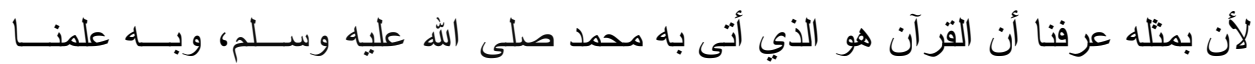

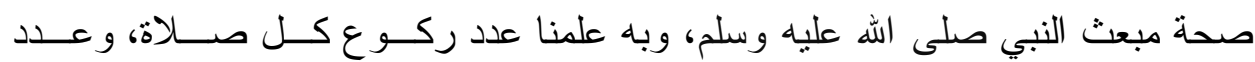
الصلو ات، وأثنياء كثيرة من أحكام الزكاة وغير ذلك مما لم بيين في القر آن تفسيره(؟).

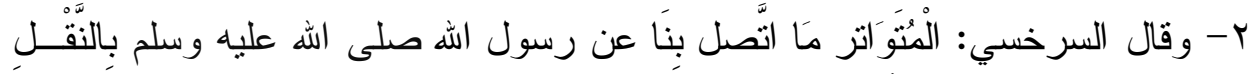

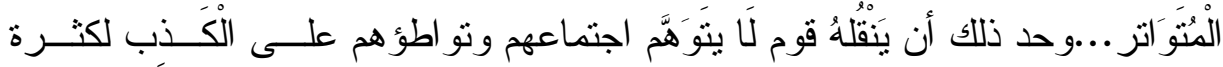

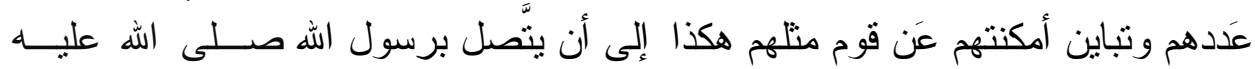

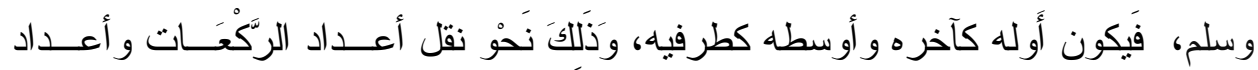

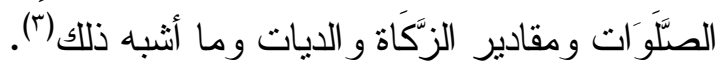

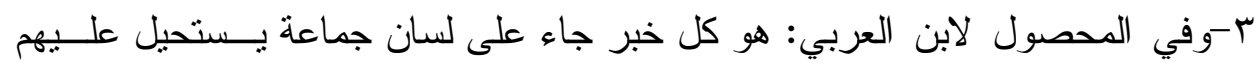

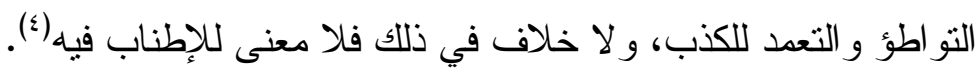

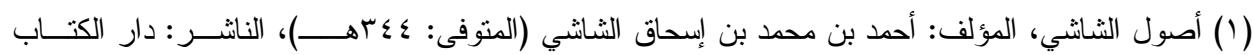

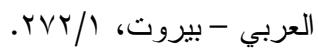
(Y) الإحكام في أصول الأحكام، المؤلف: أبو محمد علي بن أحمد بن سعيد بن حزم الأندلسي القرطبي الظاهري (المتوفى:

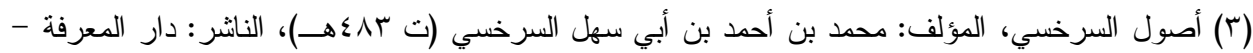

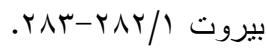
(ء) المحصول في أصول الفقه، المؤلف: القاضي محمد بن عبد الله أبو بكر بن العربـي المعـافري الاثــبيلي

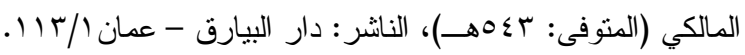


ع - و عرفه الآمدي في الإحكام بقوله: إنه عبارة عن خبر جماعة بلغوا في الكَثْةَة إلـى

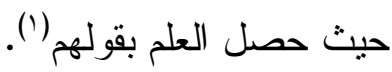
ه- وقال القر افي: هو في الاصطلاح خبر أقو ام عن أمر محسوس بــستحيل نو اطــؤهم

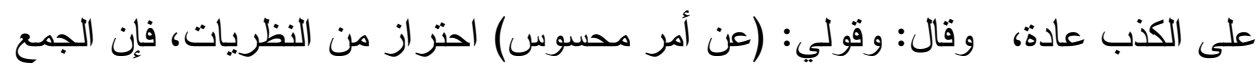

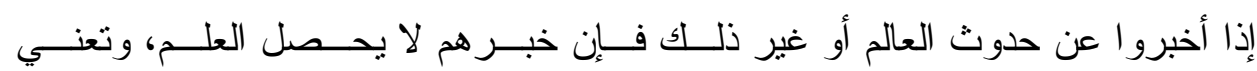
بالمحسوس ما يدرك إحدى الحواس الخمس (ז). צ- وقال البزدوي: الخبر المتو اتر الذي اتصل بك من رسول الله صلى الله عليه وسلم

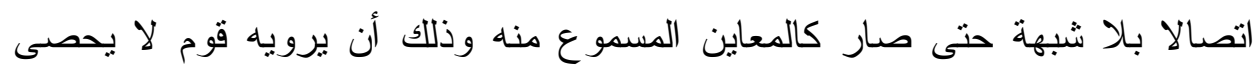

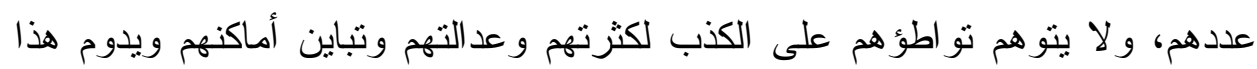

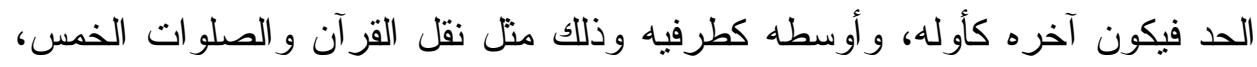

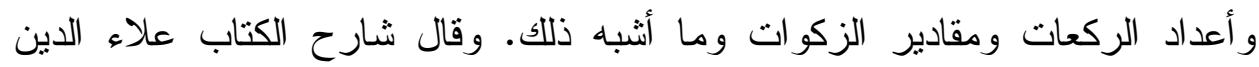
البخاري: و إنما قيد الثيخ المتواتر بقوله اتصل بك من رسول الله - صلى الله عليه

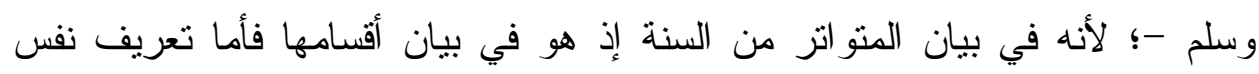

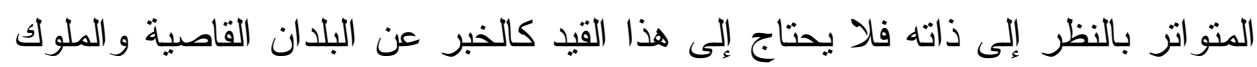

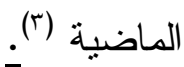

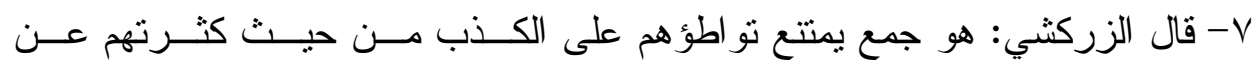
محسوس (£).

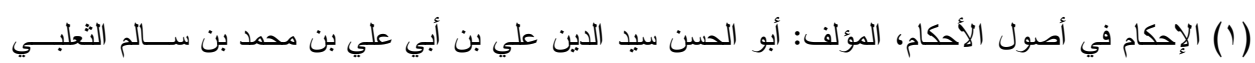

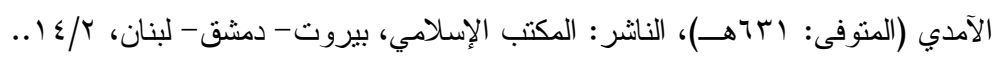

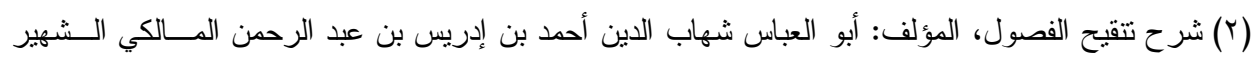

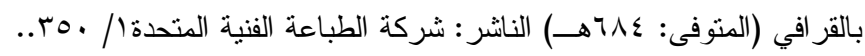

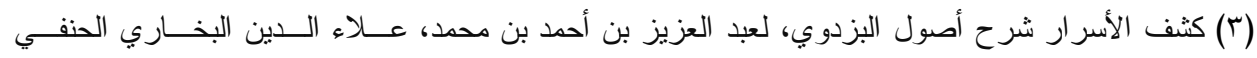

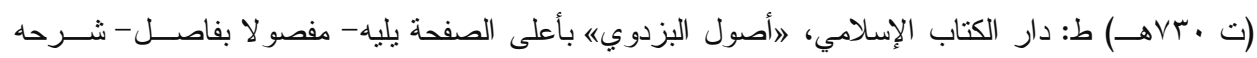

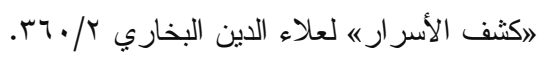

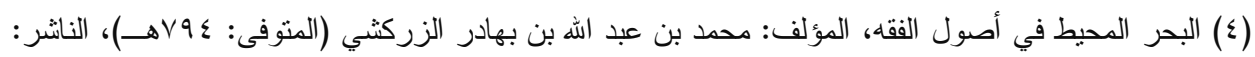

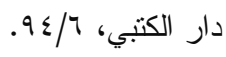




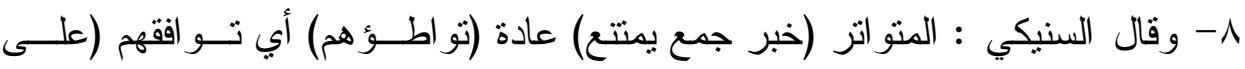
الكذب عن محسوس) لا عن معقول لجو از الغلط فيه كخبر الفلاسفة بقدم العالم ('). 9- وقال الثوكاني في ارشاد الفحول: هو خبر أقوام بلغو ا في الكثرة إلى حيث حصل العلم بقولهم (؟). • 1 - ذهب البعض إلى أن الإمام الثافعي هو أول من تحدث عن المتواتر، وهو ما

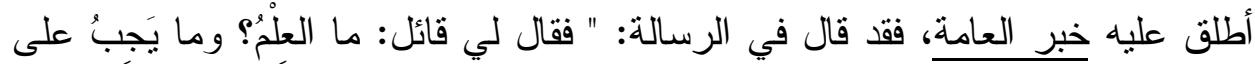

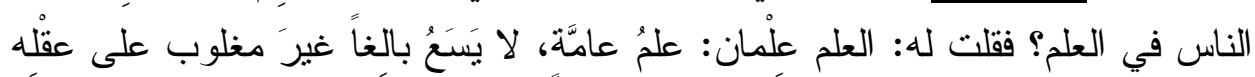

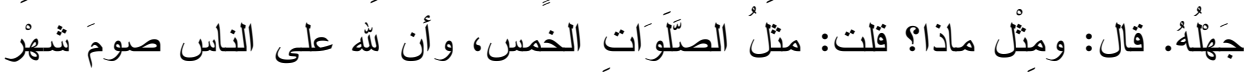

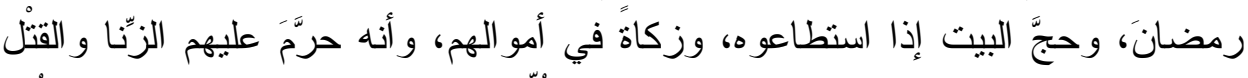

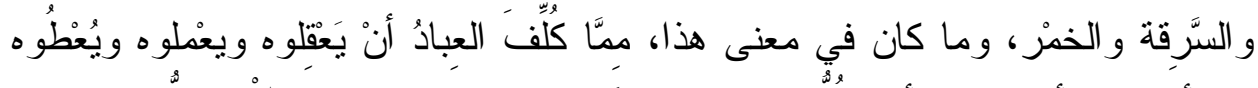

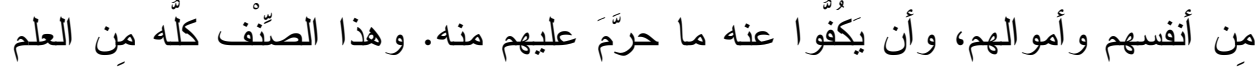

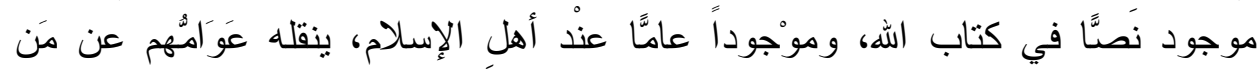

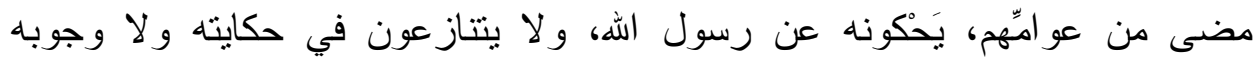

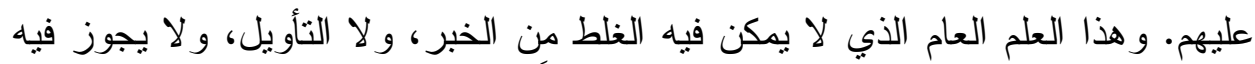

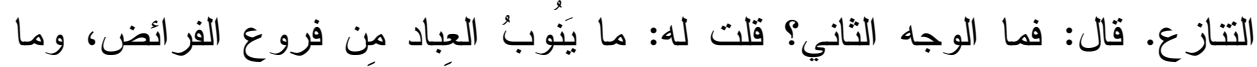

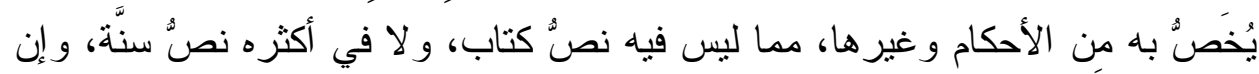

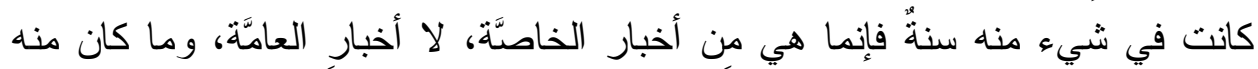

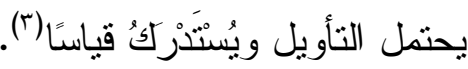
و ون خلال النظر في التعريفات السابقة للأصوليين نجدها متقاربة في المعنى إلى حد

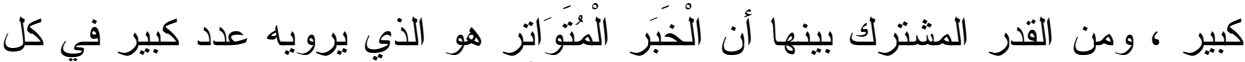

(1) غاية الوصول في شرح لب الأصول، المؤلف: زكريا بن محمد بن أحمد بن زكريا الأنصاري، زين الــدين

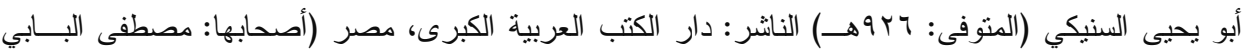

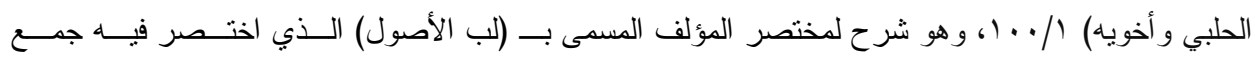

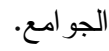
(r) إرشاد الفحول إلي تحقيق الحق من علم الأصول، المؤلف: محمد بن علي بن محمد بن عبد الله الــشوكاني

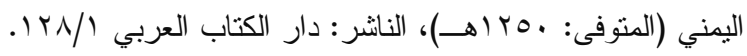

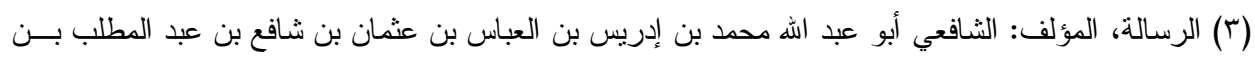

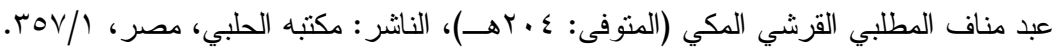


طبقة من طبقات السند، وتحيل العادة تَوَاطوُُهُمْ عَلَى الكذب لكثرتهم و عدالتهرم -كما ذكر

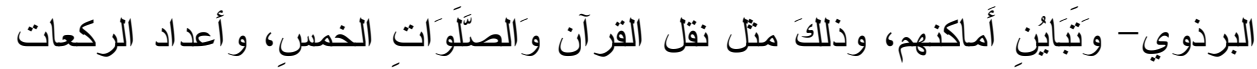

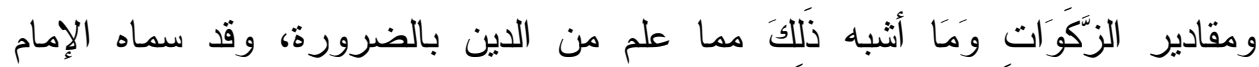

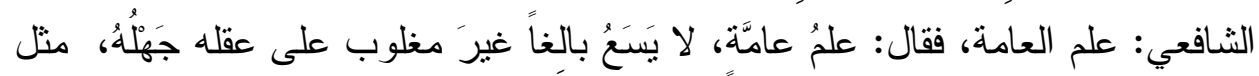

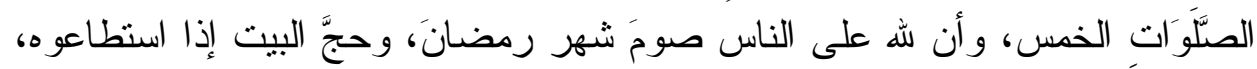

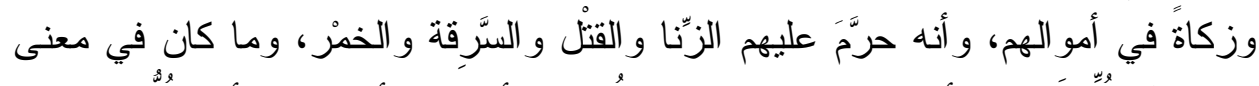

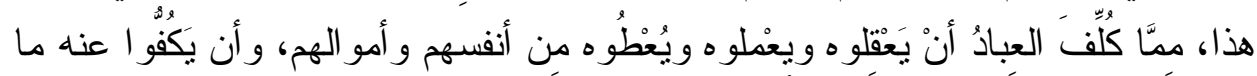

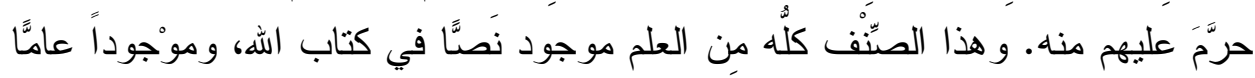

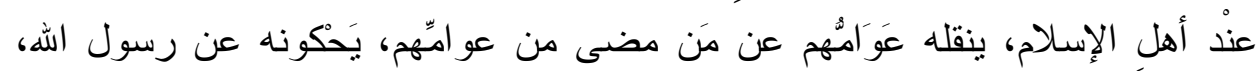

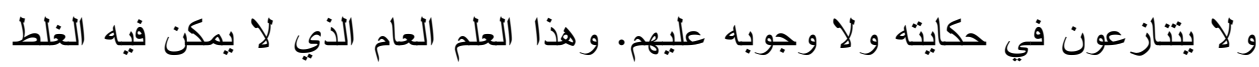

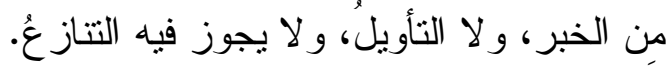

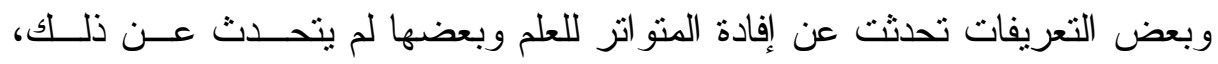

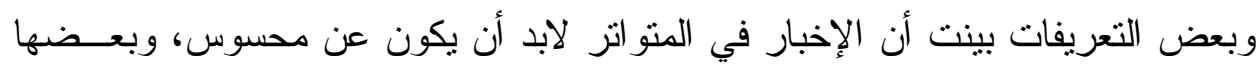

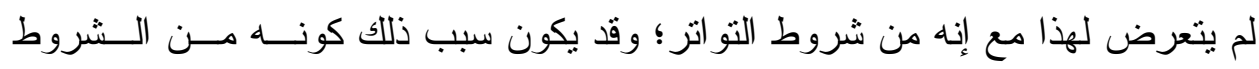

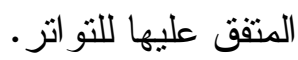

\section{r - تعريف المتواتر في اصطلاح المحدثين:}

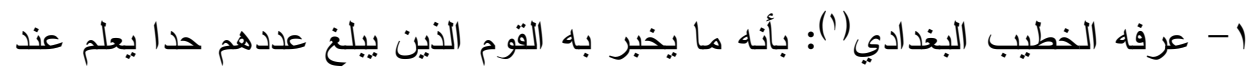

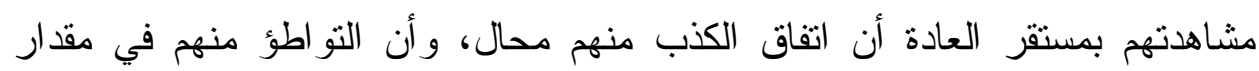

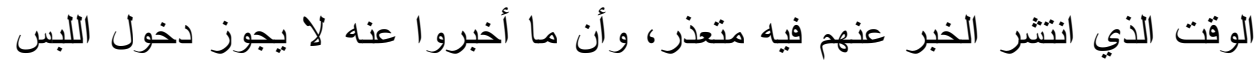

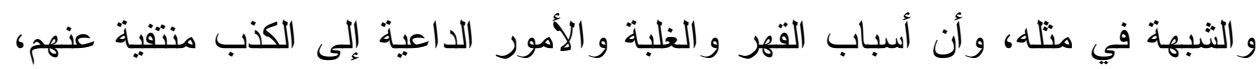
وقال: فمتى نواتز الخبر عن قوم هذه سبيلهم قطع على صدقه، وأوجب وقوع العلم ضرورة.

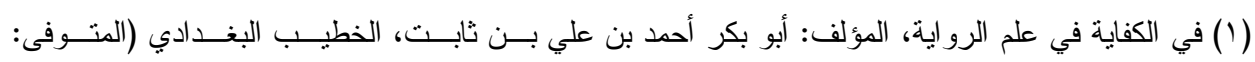

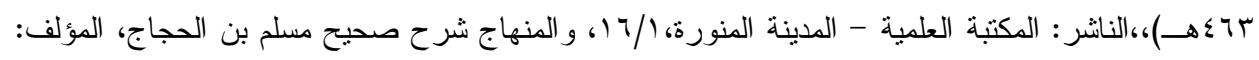

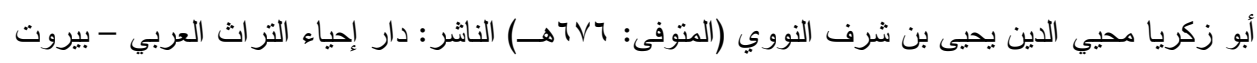

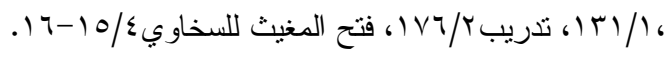




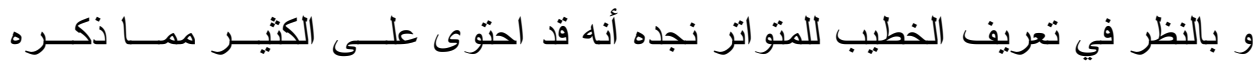

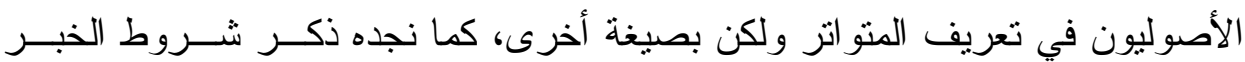
المتو اتر ، و الثمرة التي تترتب على توفر هذه الثروط، فاشترط: ا - أن بروي الحديث عدد كبير - في كل طبقة من طبقات السند من أوله إلى منتهاه-.

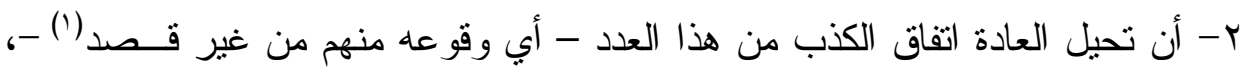
أو التو اطؤ عليه، أو الإكر اه.

r- أن يكون ما أخبروا عنه لا يجوز دخول اللبس و الثبهة في متله، وذللك بأن يخبروا الأهرا

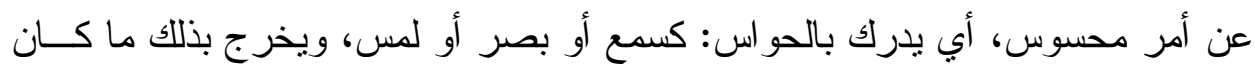
عن أمر معقول أي يدرك بالعقل، فإنه يجوز فيه اللبس و الثبهة والئ والخطأ.

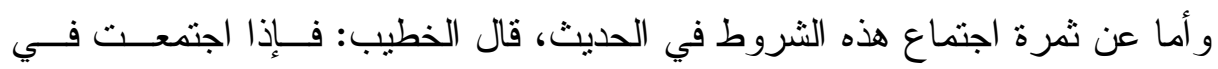

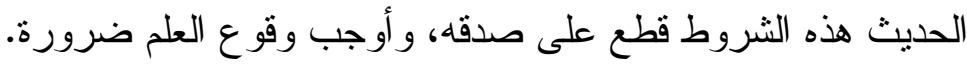

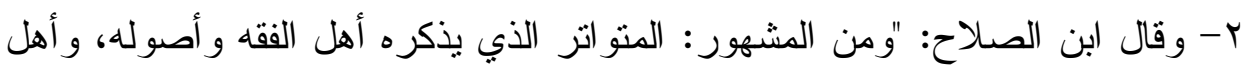

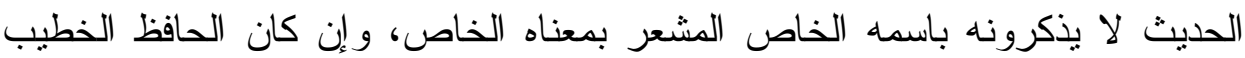

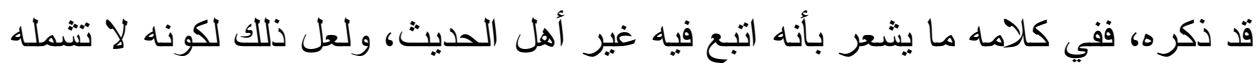

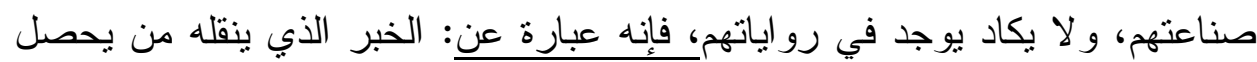

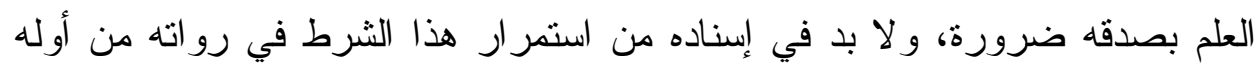
(؟) إلى منتهاه

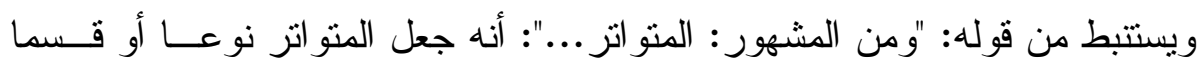

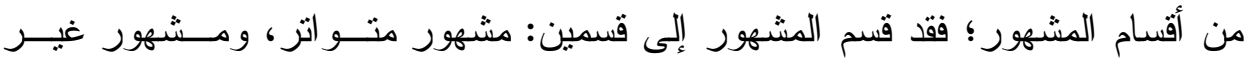

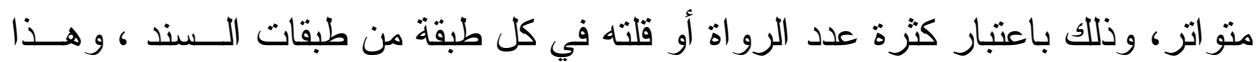
اصطلاح و لا مشاحة فيه كما يقولون. ويستتبط من قوله:" المتواتر الذي يذكره أهل الفقه و أصوله، و أهل الحديث لا لألهان يذكرونه باسمه الخاص المشعر بمعناه الخاص.....و لا يكاد يوجد في رواياتهر": أن ولن

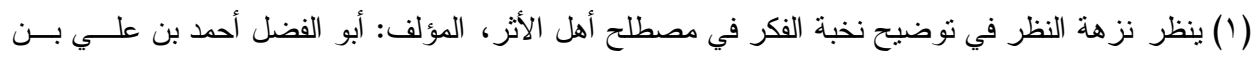

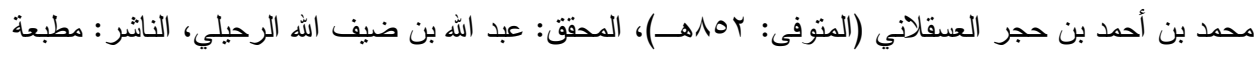

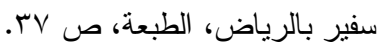

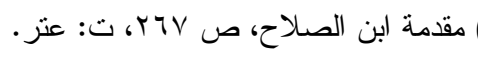


أهل الفقه وأصوله قد سبقوا المحدثين إلى الكلام عن المنواتر ، وأن المتو اتر بالمعنى

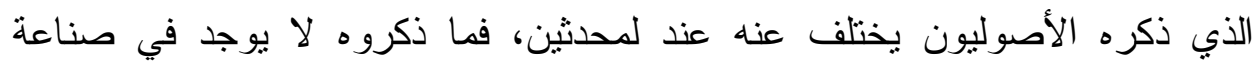
المحدثين و لا مروياتهم.

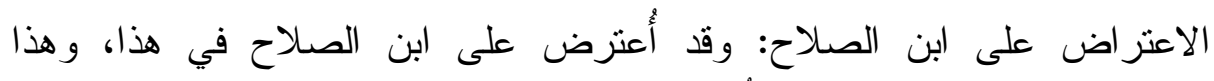

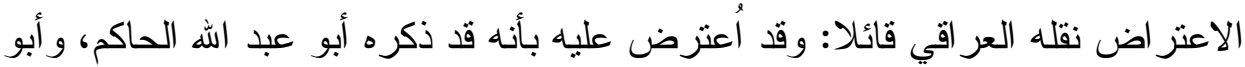

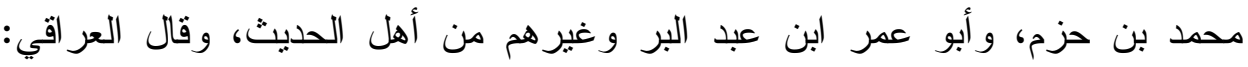

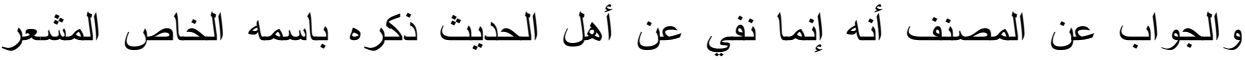

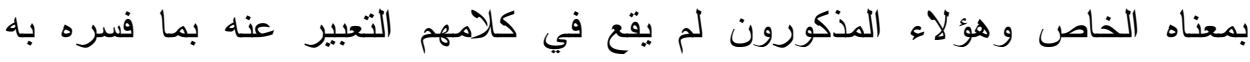
الأصوليون و إنما يقع في كلامهم أنه تواتر عنه صله صلى الله عليه وسلم كذاه وكذا أو أن فئ الحديث الفلاني منواتر وكقول ابن عبد البر في حديث المسح على الخفين أنه استفاض

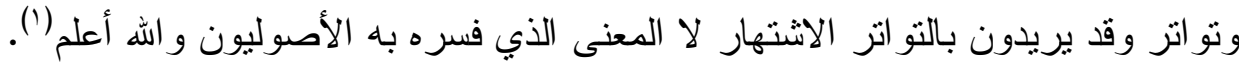

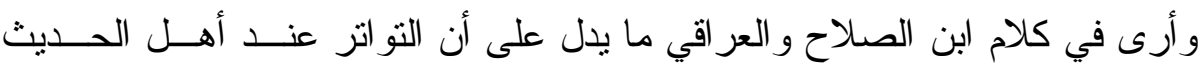

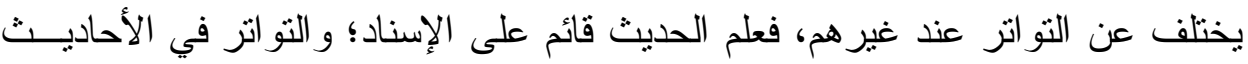

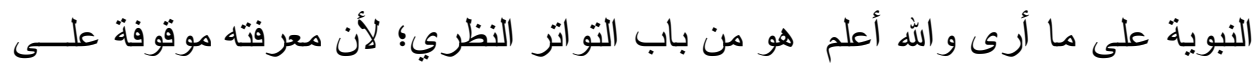

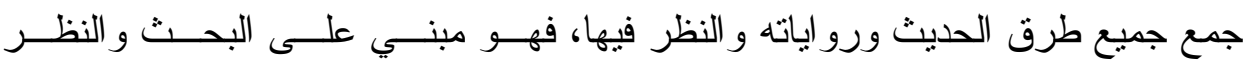

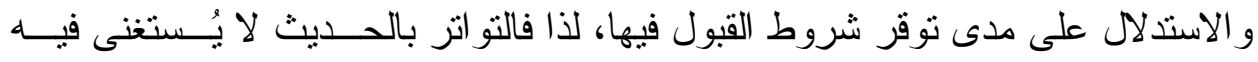

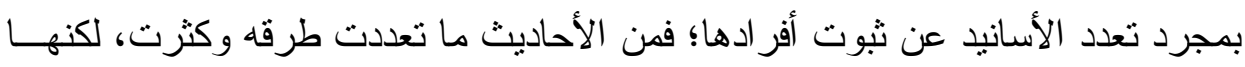

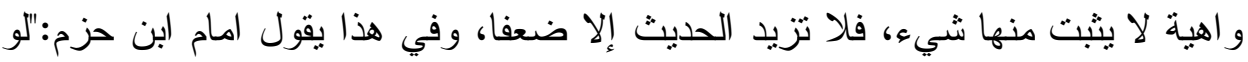

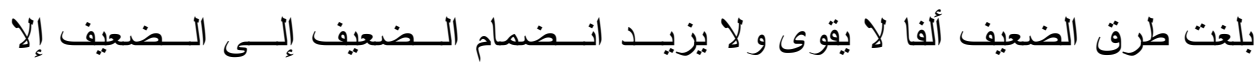

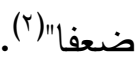
وهذا المعنى أغفله أكثر من تعرض لهذا الموضوع؛ خصوصا أن أكثر من تكلم في

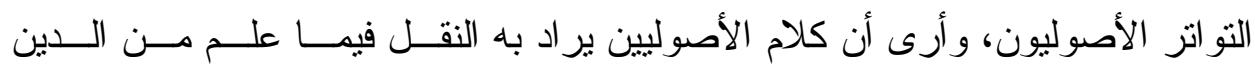

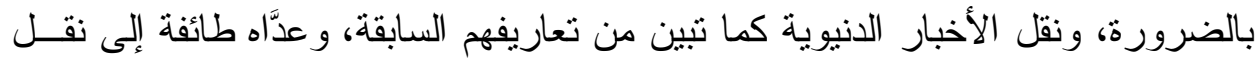

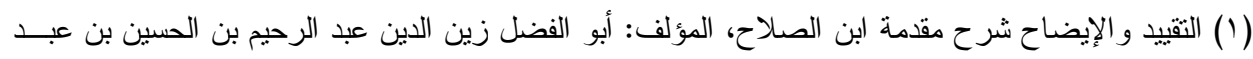

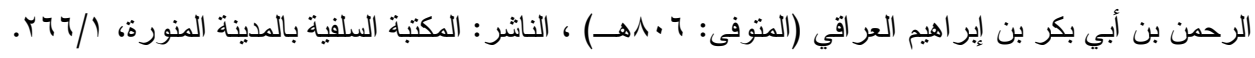

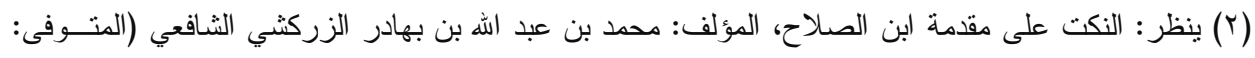




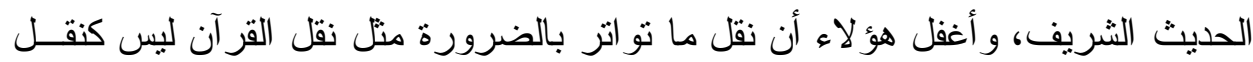

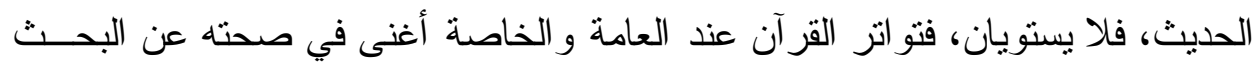

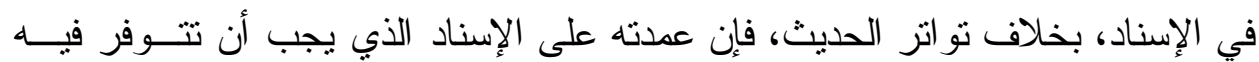

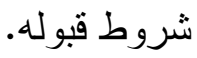

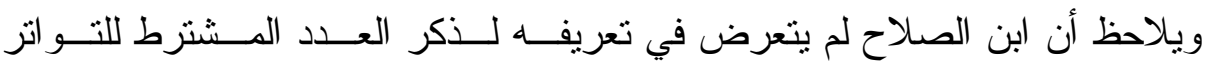

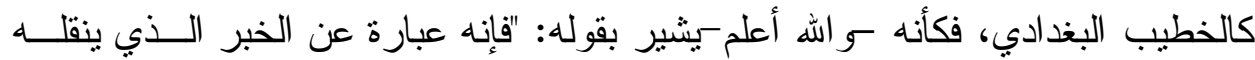

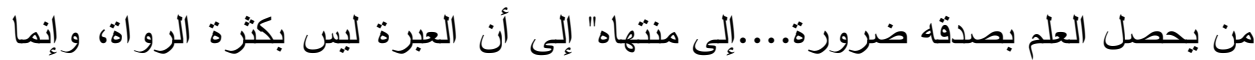

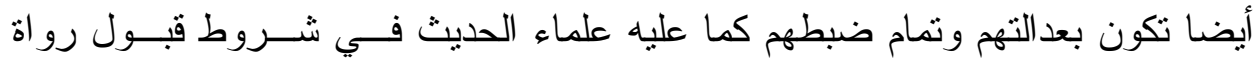

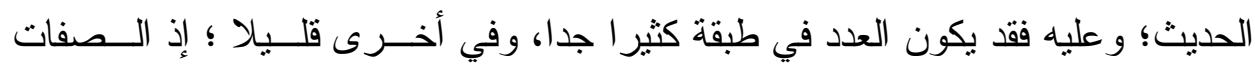
العلية في عدالة الرواة وتمام ضبطهم قد تقوم مقام العدد أو تزيد عليه (').

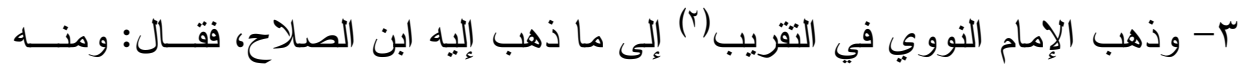

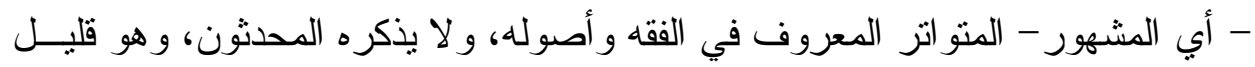

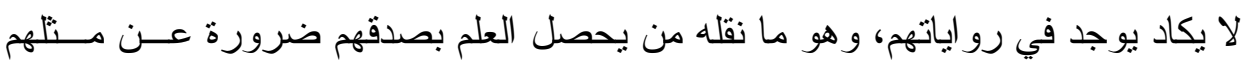

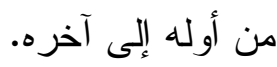

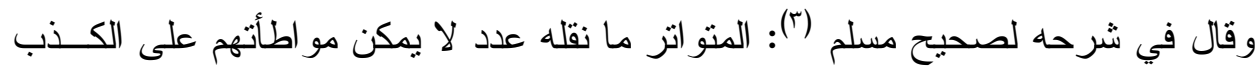

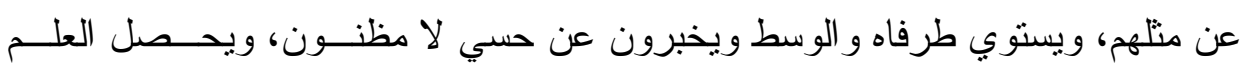

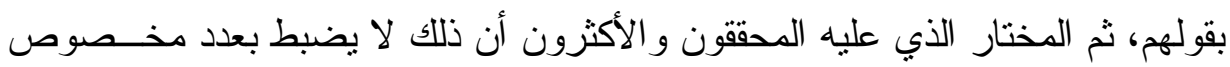
و لا يشترط في المخبرين الإسلام و لا العدالة.

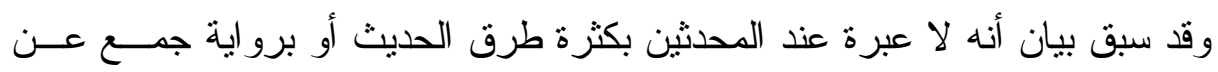

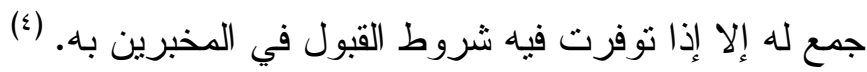

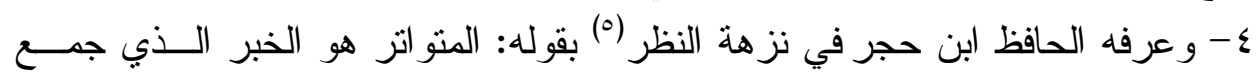

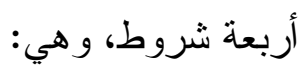

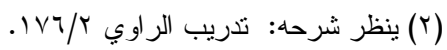

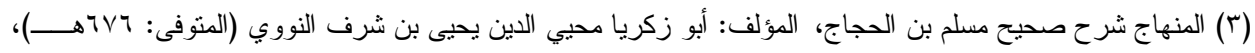

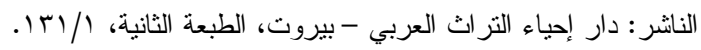

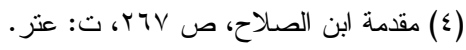

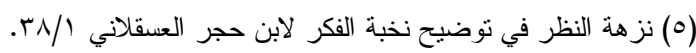


1- رو اه عدد كثير أحالت العادة تو اطؤهم، أو تو افقهم، على الكذب. ץ- رووا ذللك عن منلكه من الابتداء إلى الانتهاء. r- وكان مستتد انتهائهم الحس.

ع - و انضاف إلى ذلك أن يصحب خبر هم إفادة العلم لسامعه، فهذا هو المتو اتر .

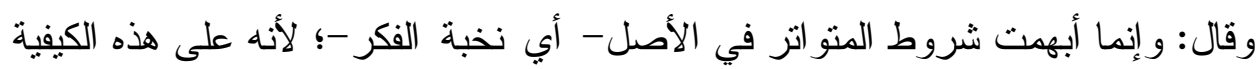

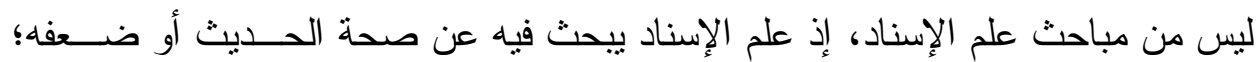

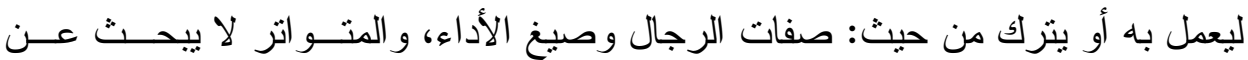

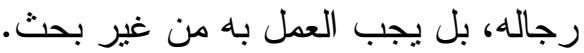
قلت: وحقيقة أرى أن ما ذكره بعض بله دن بالأئة كالإمام النووي وشيخ الإسلام الحـافظ

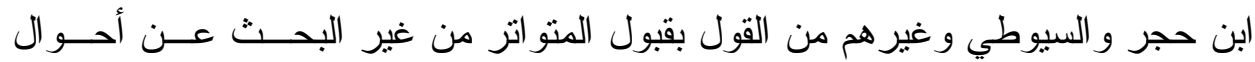

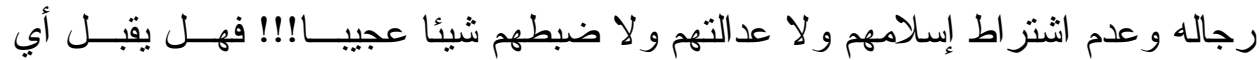

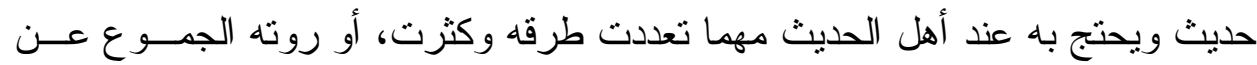

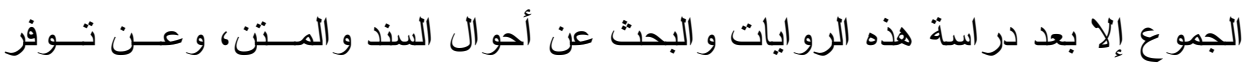

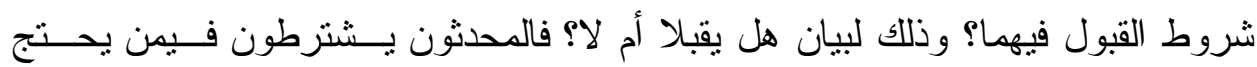

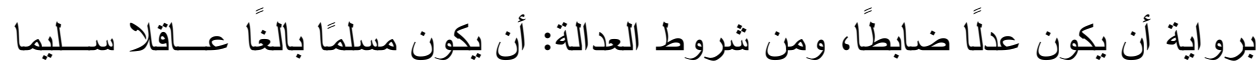

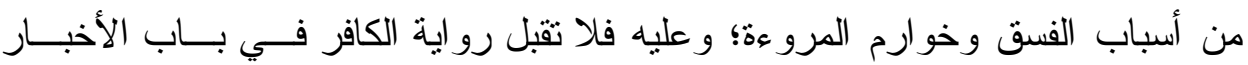

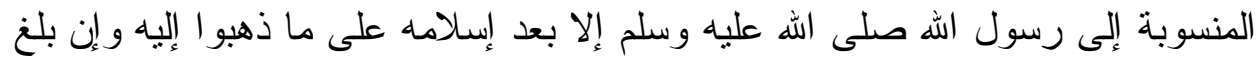

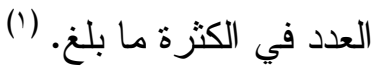
قال الكتاني: المحدثون الظاهر أنه لابد عندهم من الإسلام في رواته لأن كلامهم في

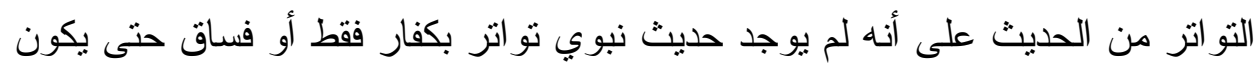

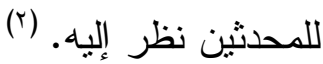

(1) قو اعد التحديث من فنون مصطلح الحديث، المؤلف: محمد جمال الدين بن محمد سعيد بن قاسم القاســي (المتــوفى:

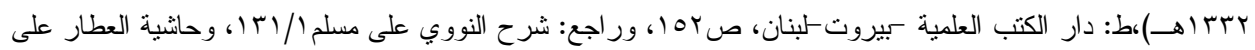

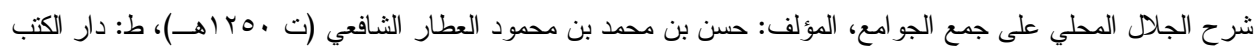

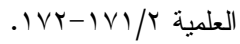
(Y) نظم المتتاثر من الحديث المتو اتر، المؤلف: أبو عبد الله محمد بن أبي الفيض جعفر بن إدريس الحسني الإدريسي الثهير

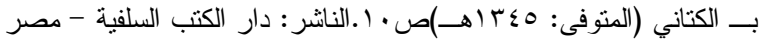




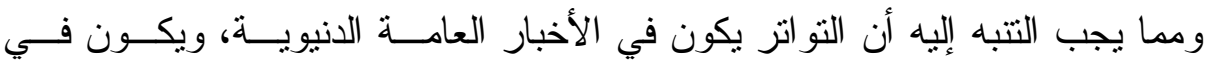

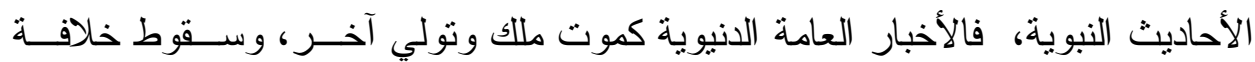

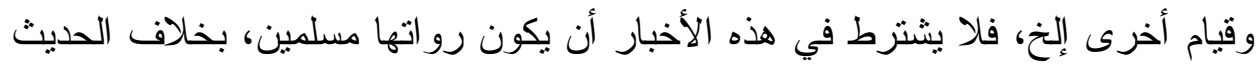

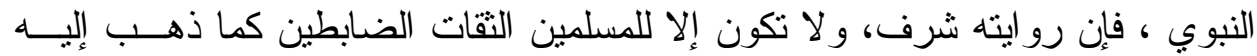
عدة من العلماء. وقد وجدت أيضا عند البزدوي وهو من أهل أصول الفقه ما يدل على انشتراطه

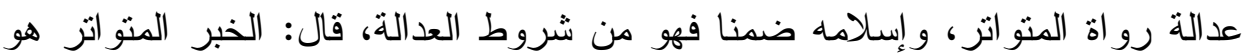
الذي اتصل بك من رسول الله صلى الله عليه وسلم اتصالا بلا شبهة حتى صار كالمعاين المسموع منه، وذللك أن يرويه قوم لا يحصى عددهم، و لا يتو هم تو اطؤ هم

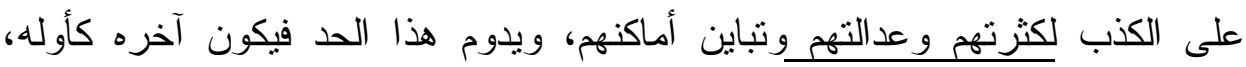

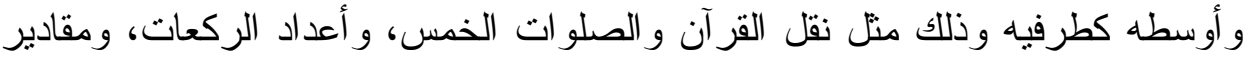

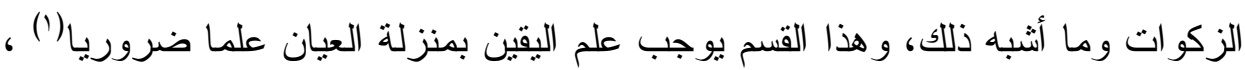
و الله أعلم. وقال القاسمي: وقع في كلام الإمام النووي في المتو اتر أنه قال: لا يشترط في الها

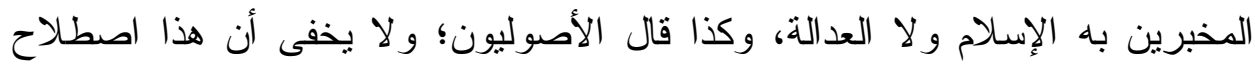
للأصوليين؛ وإلا فاصطلاح المحدثين فيه، أن يرويه عدد من المسلمين؛ لأنهم اشترطو الإلها

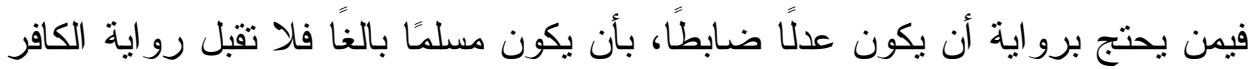

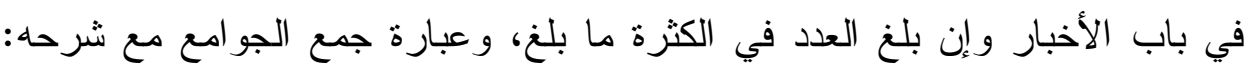

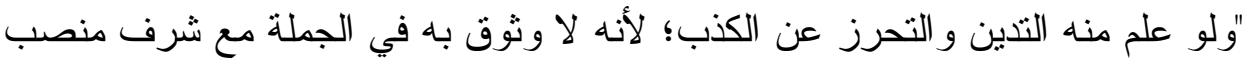

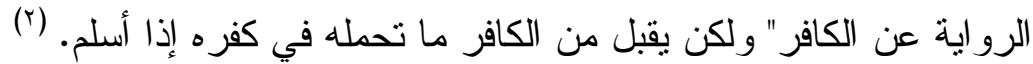

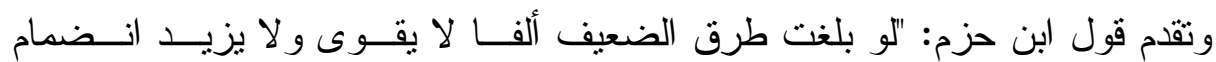

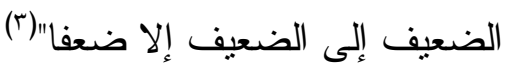

(1) النكت على مقدمة ابن الصلاح، المؤلف: أبو عبد الله محمد بن عبد اللهـــن بهـادر الزركـشي الـشافعي

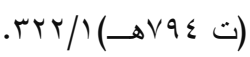

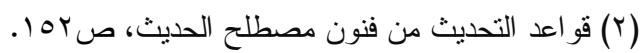

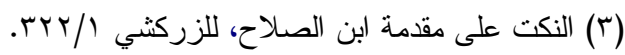


قلت: وهذا ما أذهب إليه و أرجحه؛ و أنه لابد من توفر شروط القبول فــي الـــراوي

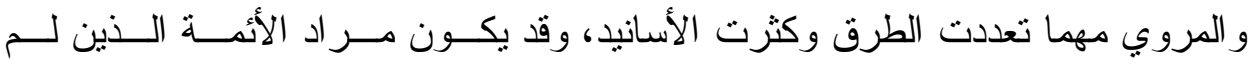

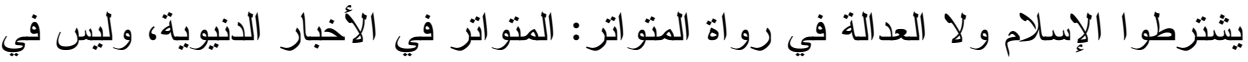

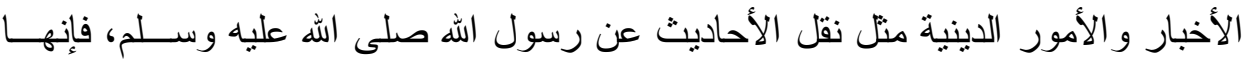
تصبر شر عا إلى يوم الدين، و الهه أعلم.

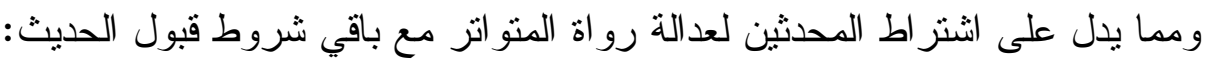

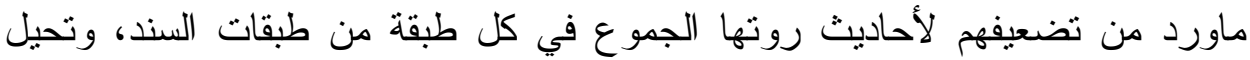
العادة اتفاقهر على الكذب، وكان مستتد خبرهم الحس (').

(1) كحديث: (طلب العلم فريضة على كل مسلم)، قال الكتاني في كتابه "نظم المنتاثر من الحديث المتواتر": ذكر السخاوي في

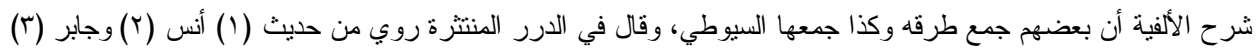

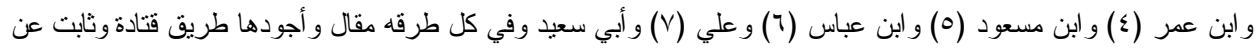
أنس وطريق مجاهد عن ابن عمر وأخرجه ابن ماجه عن كثير بن شنظير عن محمد بن سيرين عن أنس وكثير مختلف فيه وانيه

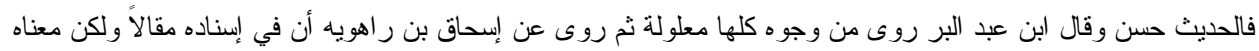

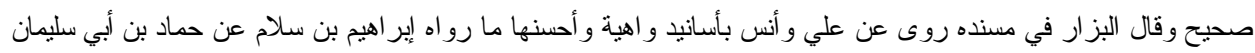

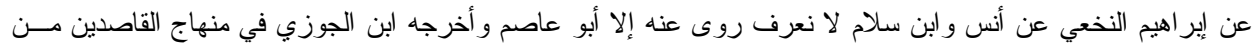
جهة أبي بكر بن أبي داود حدثنا جعفر بن مسافر حدثنا يحيى ابن حسان عن سليمان ابن قرم عن ثنابث البناني عن أنس فال البال

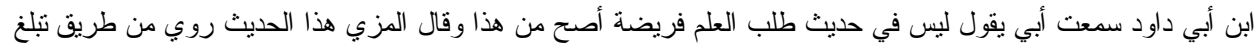

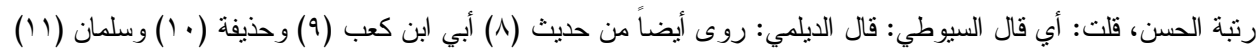

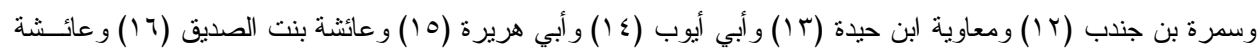

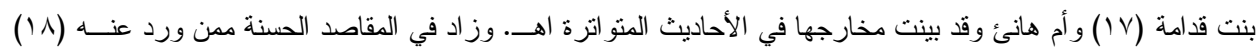

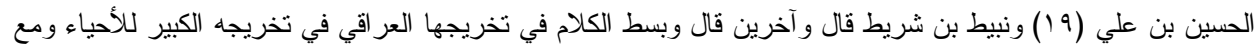

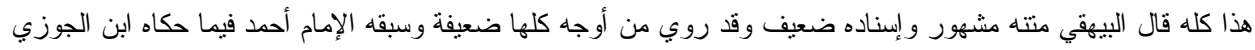

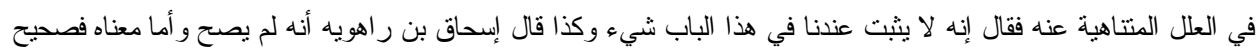

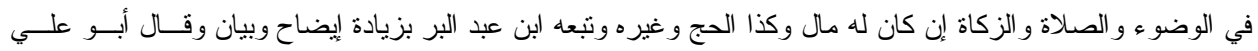

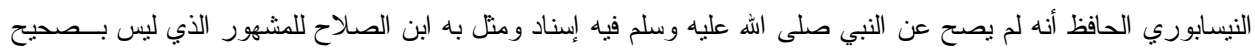

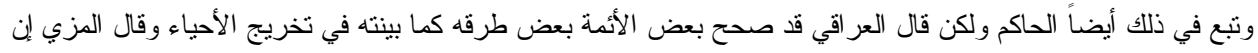

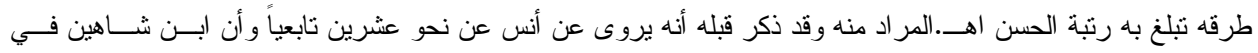

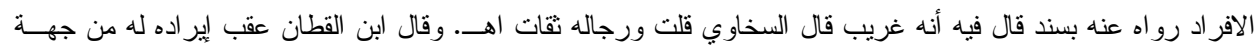

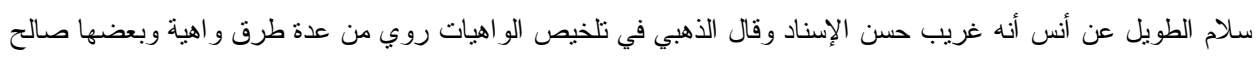

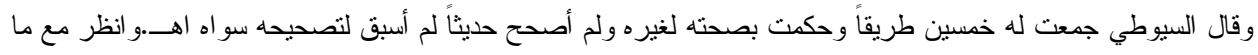

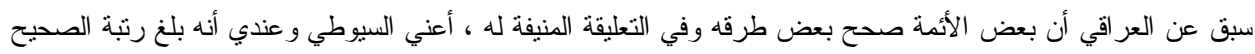

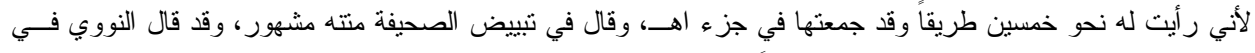

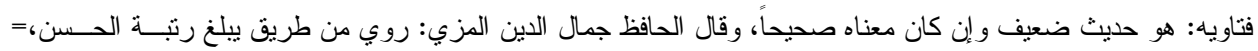




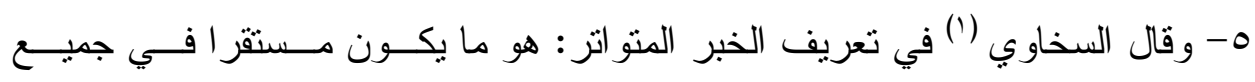

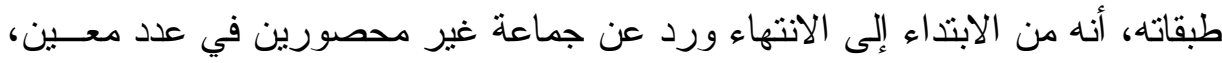

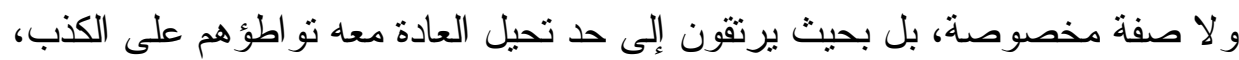

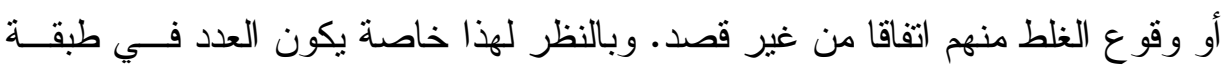

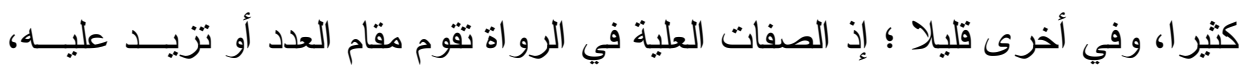

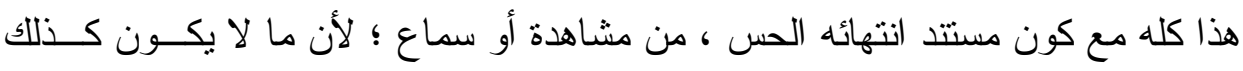

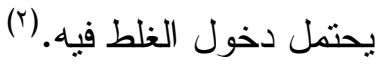

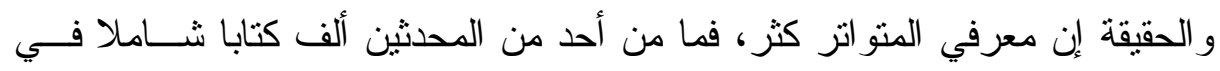

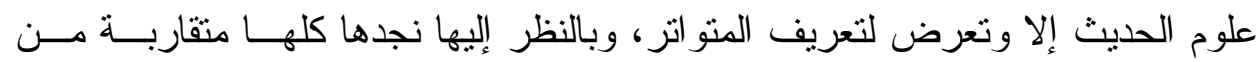
بعضها جدا.

وبعد هذا العرض لتعريف المتو اتز عند بعض الأصوليين و المحدثين يمكـن أن نـــل

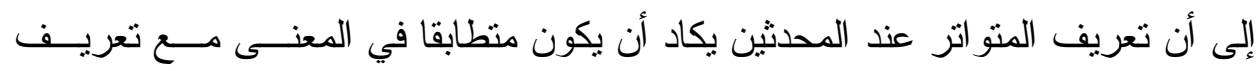

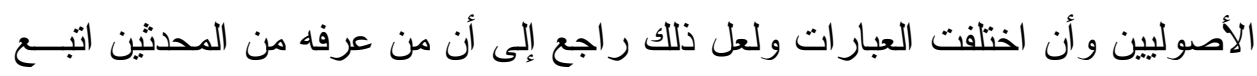

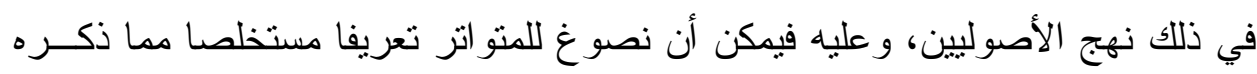
الأصوليون و المحدثون وما اشترطه المحثنون لقبول الحديث، فنقول هو :

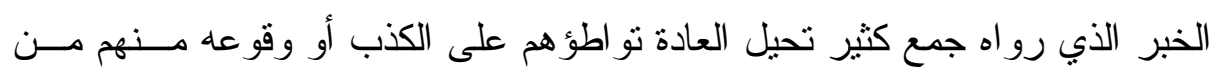

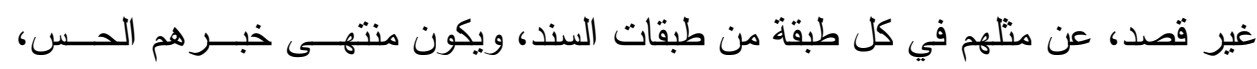

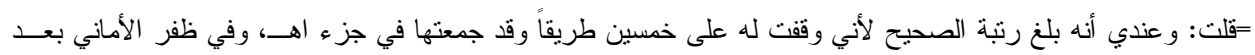

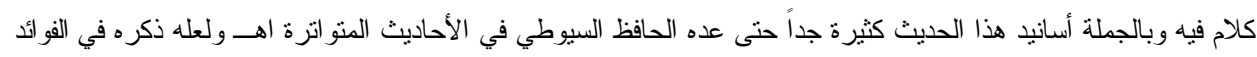

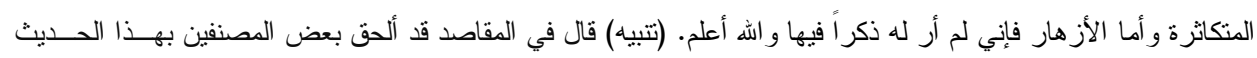

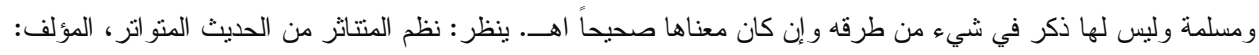

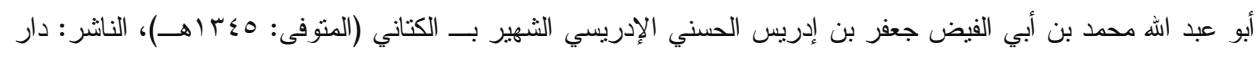

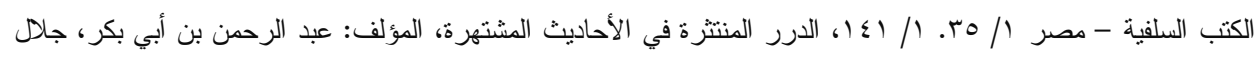

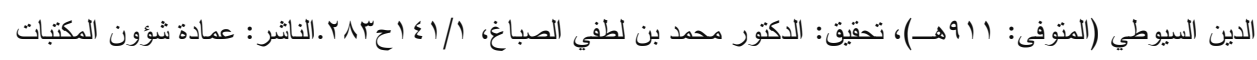
- جامعة الملك سعود، الرياض.

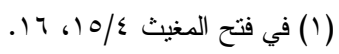

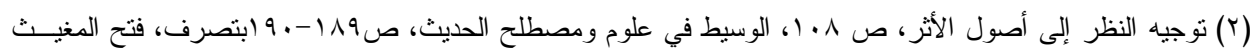

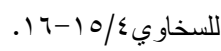


وتوفرت فيه شروط قبول الحديث عند المحدثين، ويصحب خبرهم إفادة العلــم بنفـسه لسامعه.

\section{المبحث الرابع}

\section{شروط الخبر المتواتر}

بالنظر في تعريف المتواتز يتضح أن الخبر لا يحكم له بالتواتر إلا إذا تحققت فيه الشروط التالية: - الثنر

1- أن يرويه جمع كثير، بحيث أن بيلغ عدد رواته إلى مبلغ من الكثرة يمنع في

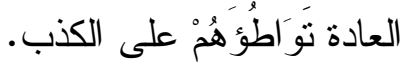

وقد اختلف العلماء في عدد هذا الجمع الكثير الذي يحصل به التواتر، وهل هو

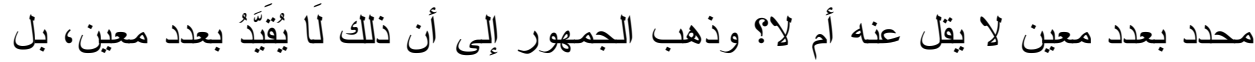

ضابطه: حصول العلم الضروري باه، فإذا حصل ذللكَ علمنا أنه منو اتر ، و إلا فلا. وذهب البعض إلى أنه لا يتحقق التواتر بأقل من خمسة، وقيل: سبعة، وقيل: أقلة عشرة؛ لأنها أول جموع الكثرة-وممن ذهب إليه الإمام السيوطي، قال في الأزهار المتناثرة في الأخبار المنو اترة أن كل حديث رو اه عشرة من الصحابة فهو منو اتر عندنا معشر أهل الحديث اهـ، وقيل: اثتا عشر، وقيل: عشرون، وقيل: أربعون، وقيل:

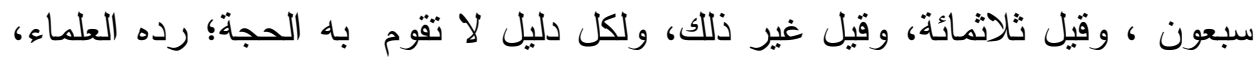

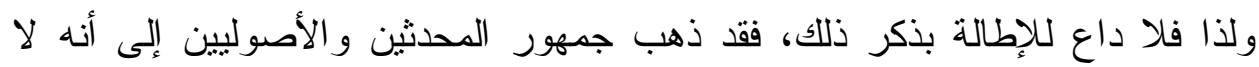

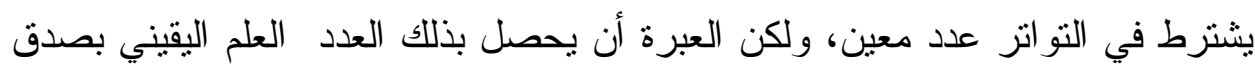
المنقول. (') (1)

قال ابن تيمية(؟) "فالصواب الذي عليه الجمهور أن المتواتر ليس له عدد محصور ، بل

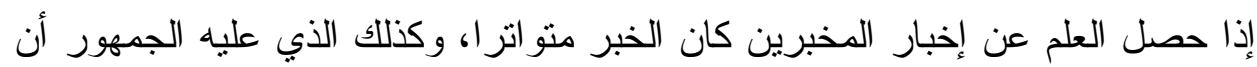

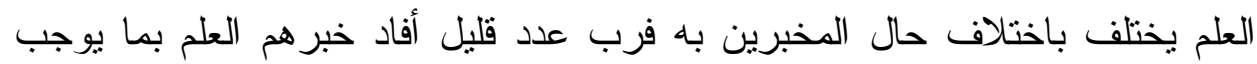
صدقهم، وأضعافهم لا يفيد خبرهم العلم، ولهذا كان الصحيح أن خبر الواحد قد يفيد

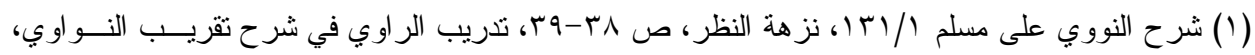
$.1 V 7 / r$

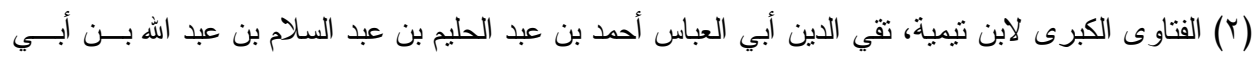

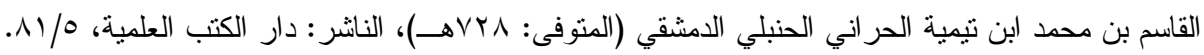


العلم إذا احتقت به قرائن تفيد العلم، وعلى هذا فكثير من منتن الصحيحين منواتر اللفظ

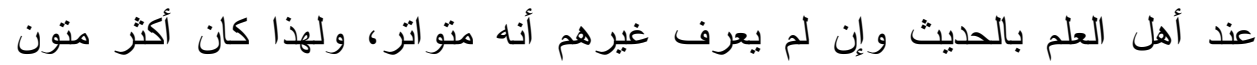
الصحيحين مما بعلم علماء الحديث علما قطعيا أن النبي صلى الله عليه وسلم قاله: تارة

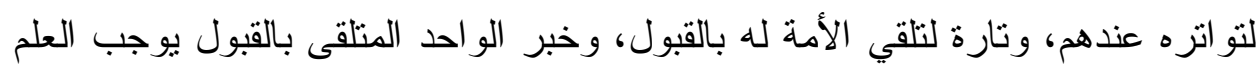
عند جمهور العلماء من أصحاب أبي حنيفة ومالك و الثافعي و أحمد.

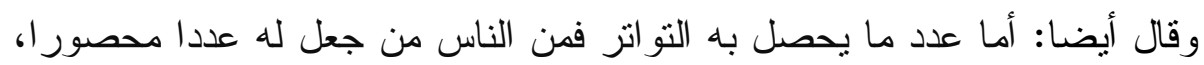

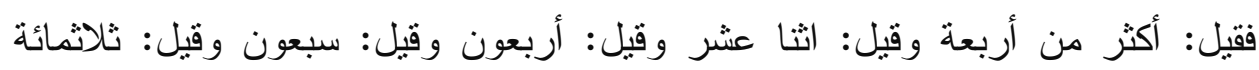
وثلاثة عشر وقيل: غير ذلك. وكل هذه الأقوال باطلة لتكافئها في الاعوى. و الصحيح الذي عليه الجمهور : أن التواتر ليس له عدد محصور و العلم الحاصل بخبر من الأخبار

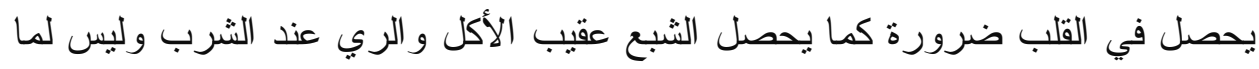
يشبع كل واحد ويرويه قدر معين؛ بل قد يكون الثبع لكثرة الطعام وقد يكون لجودته

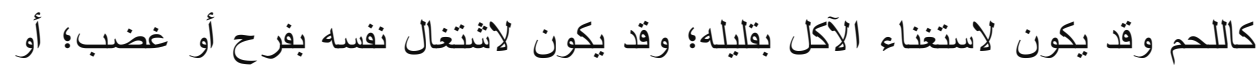

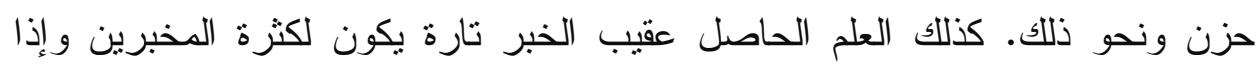

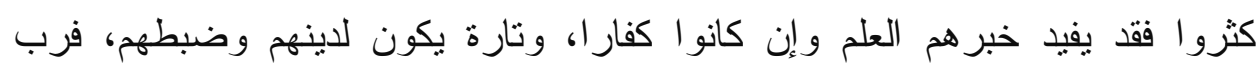

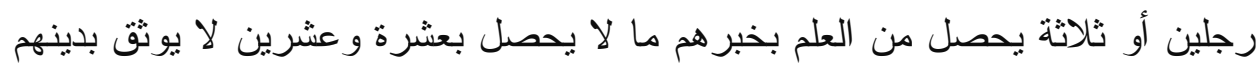

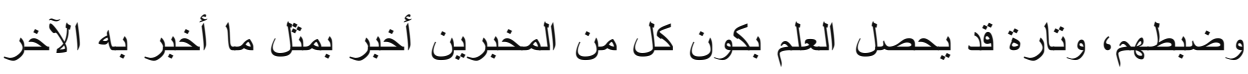

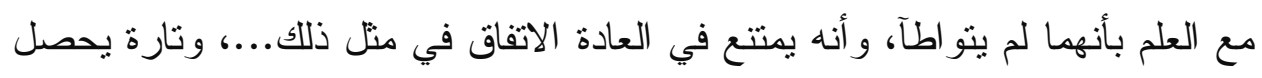

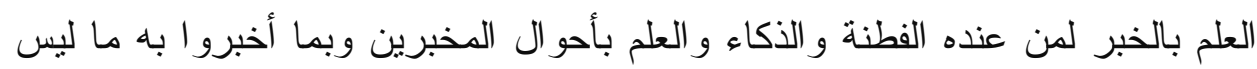

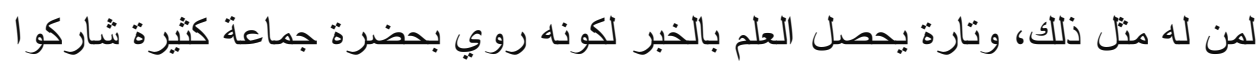

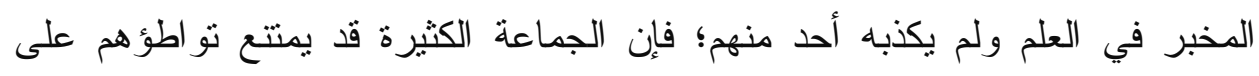

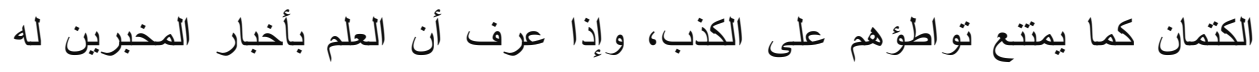
أسباب غبر مجرد العدد علم أن من قيد العلم بعدد معين وسوى بين جميع الأخبار في وإني ذللك فقد غلط غلطا عظيما' (1). r- - أن يكون هذا الجمع بحيث يحيل العقل تو اطؤهم على الكذب أو صدوره مــنهم

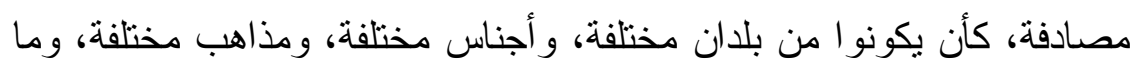

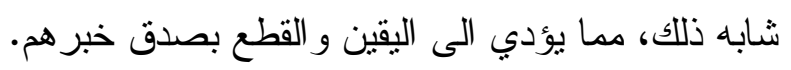




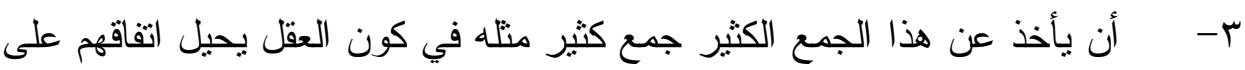

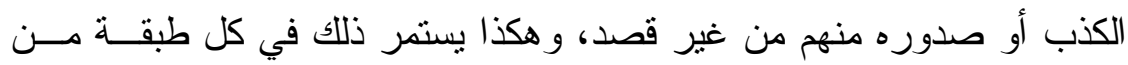

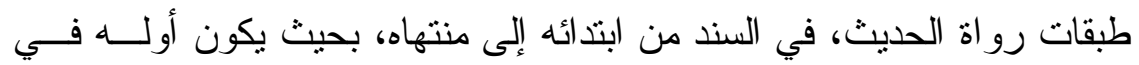

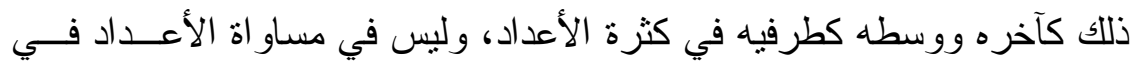

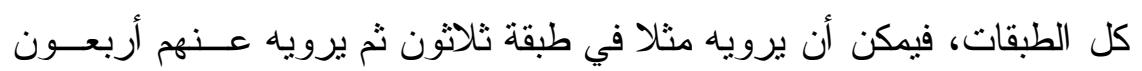
و عنهم خمسون و هكذا.

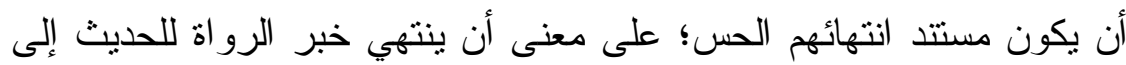
$-\varepsilon$

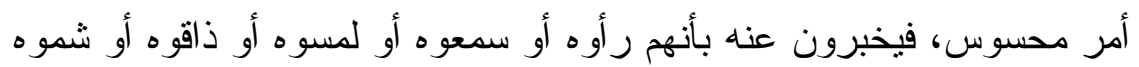

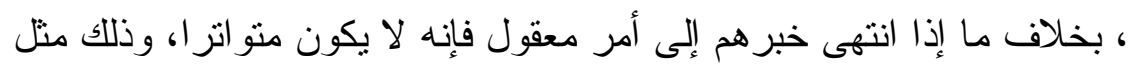

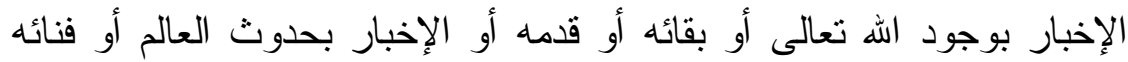

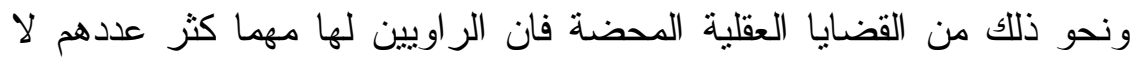

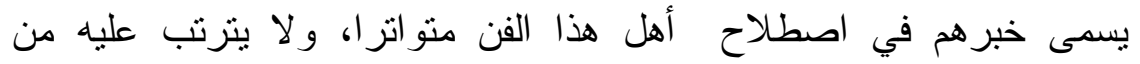

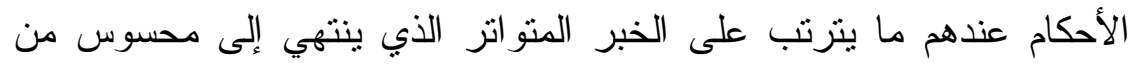
المحسوسات؛ وذلك أن غير المحسوس من القضايا العقلية يمكن أن يدخلها الخطأ، ويقع فيه الاشتباه و الخطأ، وبذلك يحصل فيه اللبس و التمويه، وليس

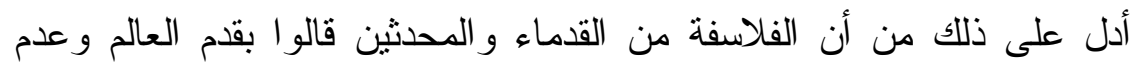
فنائه، وكثز الناقلون عنهم حتى بلغو ا من الكثرة جدا يحيل العقل معه تو اطؤهم

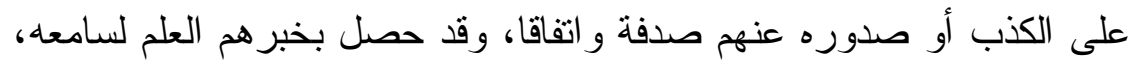
ومع ذللك قام الاليل القاطع على خطئهم فيما اعتقدوه، و البرهان الساطع على ولى ولى

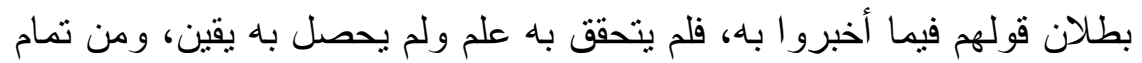

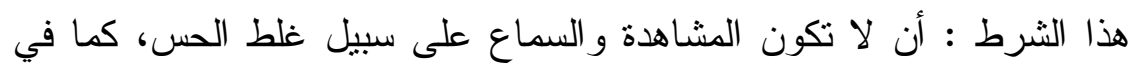

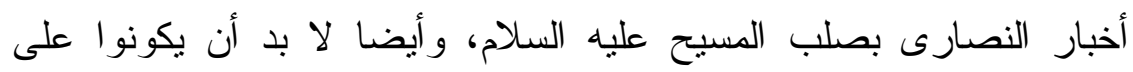

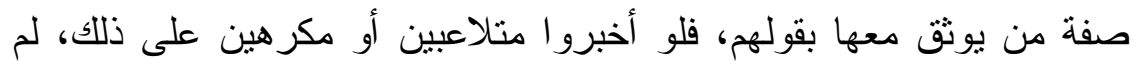

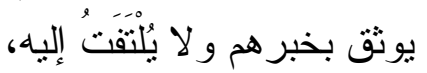
ويجب التتبه إلى أن هذه الثروط السابقة هي للمتو اتر في الأمور الدنيوية،

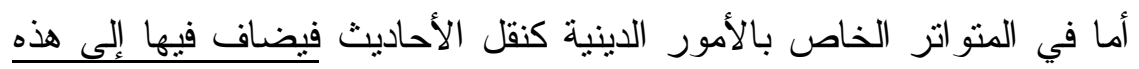


الثروط أن تتوفر فيه شروط القبول عند المحدثين، وهي : اتصال السند،

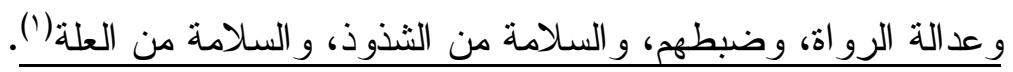

\section{المبحث الخامس}

\section{أقسام الخبر المتواتر}

ينقسم الخبر المتواتر باعتبار اللفظ و المعنى إلى قسمين:

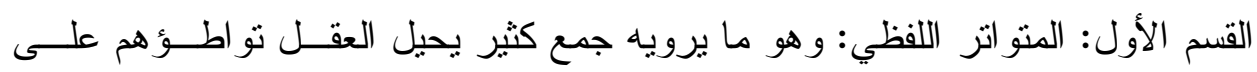

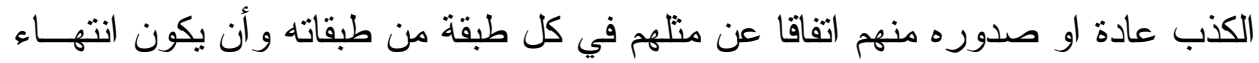

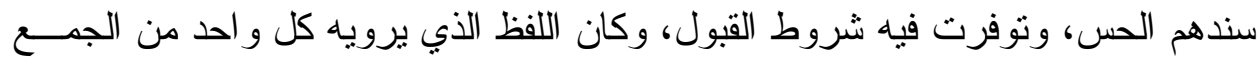
الكثير في كل طبقة من طبقاته هو عين ما يرويه الآخر منهم بلفظه، فيتحد لفظ الحديث

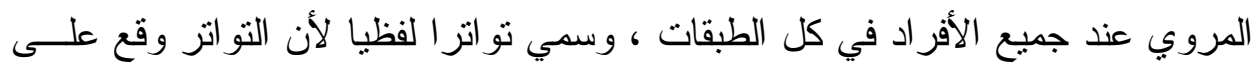

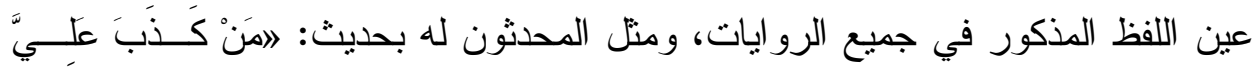

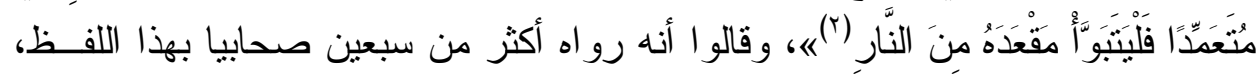

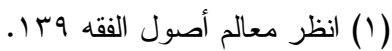

(Y) أورده الكتاني في نظم المنتاثر : وقال: "أورده في الأزهار -أي الإمام السيوطي- مصدراً به من حديث علي

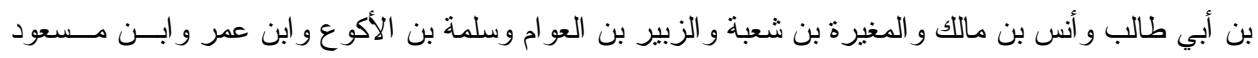

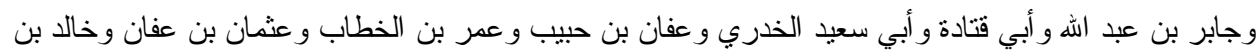

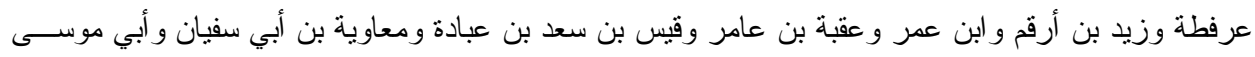

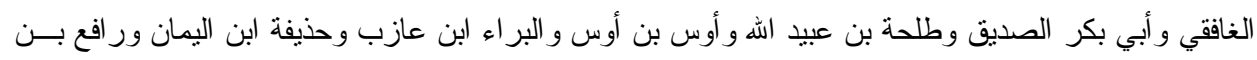

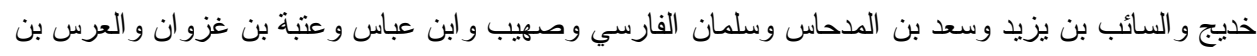

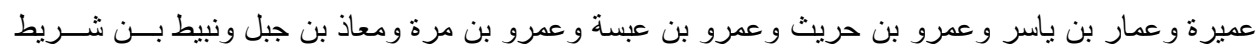

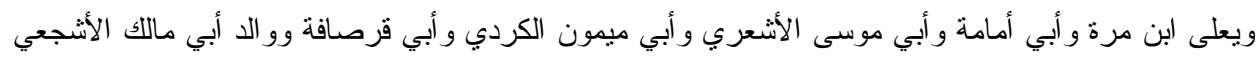

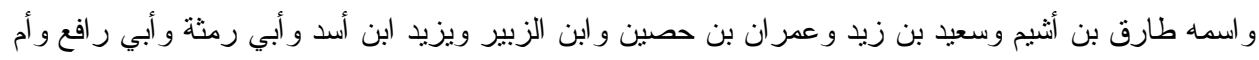

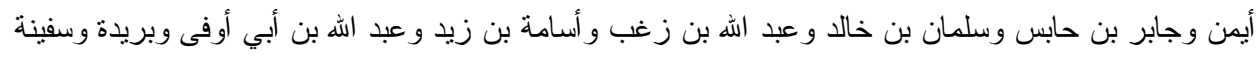

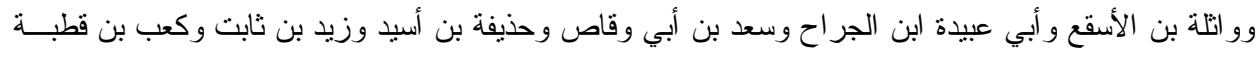

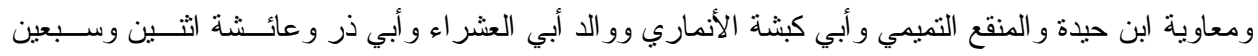

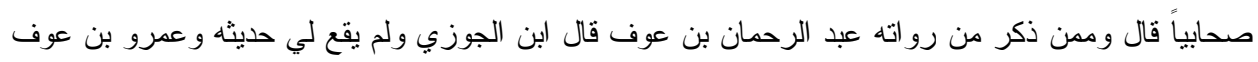

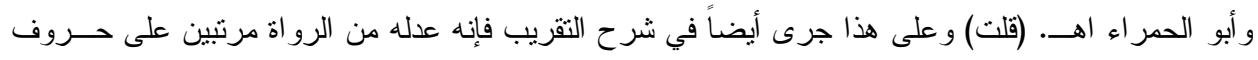

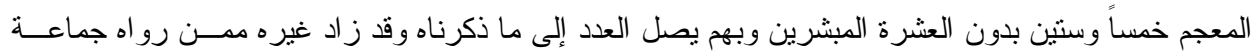
آخرين انظر شرح الأحياء وقد قالو أن البخاري أخرجه في العلم من حديث علي و الزبير بن العــوام وأنسـس 
منهم العشرة المشهود لهم بالجنة - كما قال الحافظ العراقي (') ، ثم رواه عنهم من طبقة

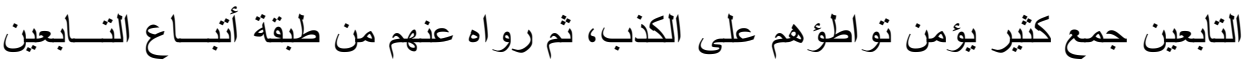

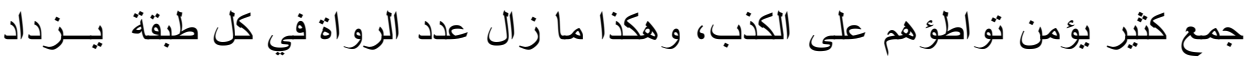
حتى وصل إلى من خرجه في أصول كتب الحديث مثل البخاري ومسلم وغير هما. القسم الثاني: المنوتر المعنوي: وهو الحديث الذي يرويه جمع كثير يحيل العقل تو اطؤهم على الكذب عادة أو صدوره منهم اتفاقا عن منلهم في كل طبقة من طبقاته و أن يكون انتهاء سندهم الحس، وتوفرت فيه شروط القبول، وكان اللفظ الذي يرويه كل و احد من الجمع الكثير في كل طبقة من طبقاته ليس هو عين ما برويه الآخر منهم

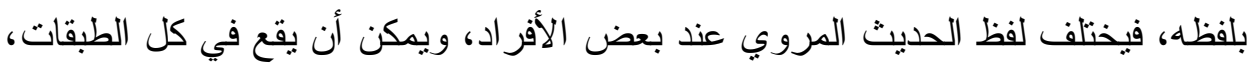

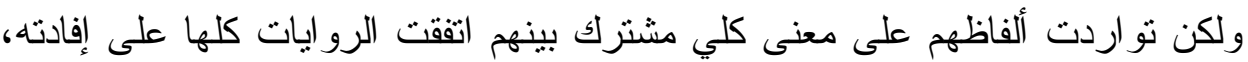
وسمي تو اتز ا معنويا لأن التواتر وقع على معلى المعنى الكلي المشترك المستفاد من جميع

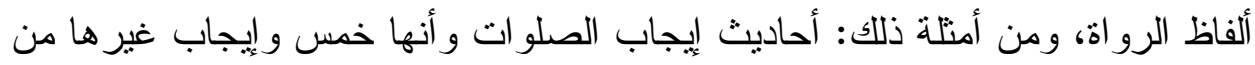
بقية أركان الدين الخمسة كثيرة جداً وهي بالغة حد التواتر أو تزيد عليه لكن تواتر هات أنها

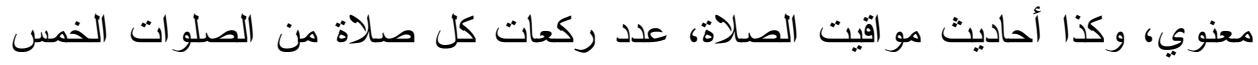
وما تشتمل عليه كل ركعة من الركوع و السجود و الرفع منهما ونزتيب ذللك، وكأحاديث

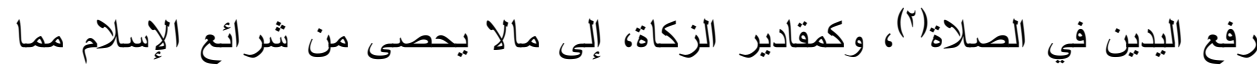

$=$

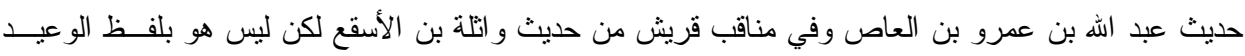

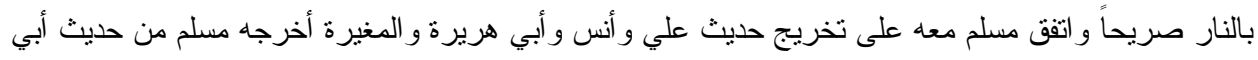

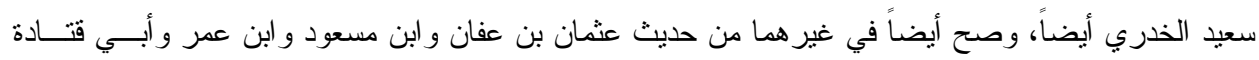

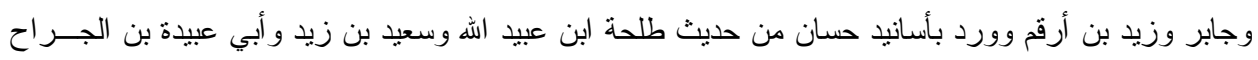

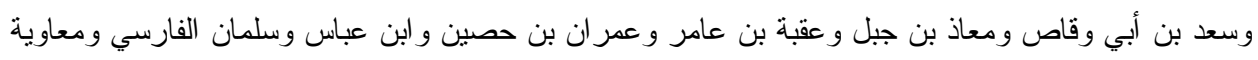

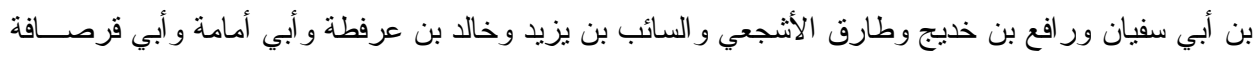

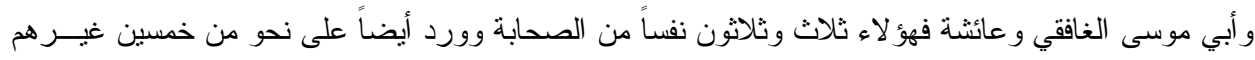

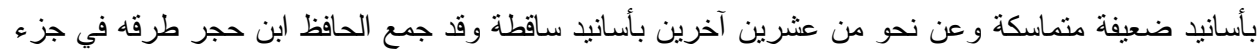

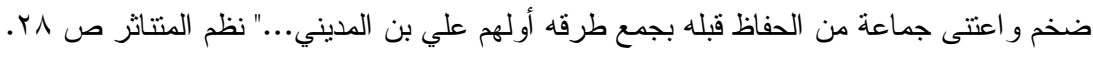

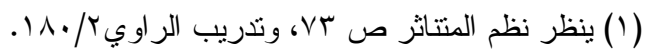

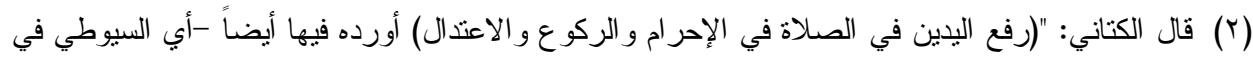

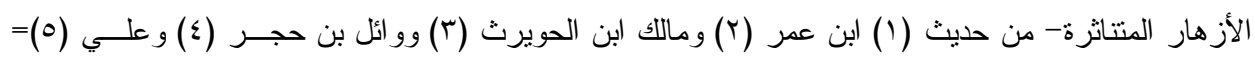


أطلق العلماء المتو اتر المعنوي العملي، وهو ما علم من الدين بالضرورة، ونواتر عند

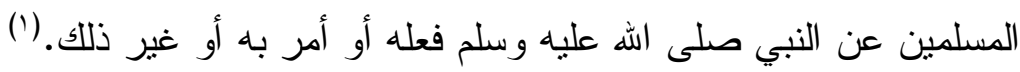

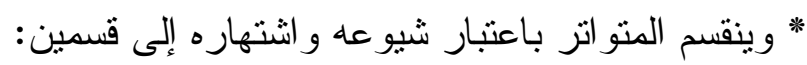

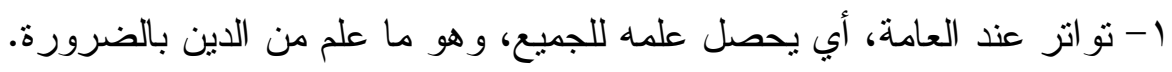
r- نواتز عند الخاصة، لا يحصل علمه إلا للعلماء المتخصصين.

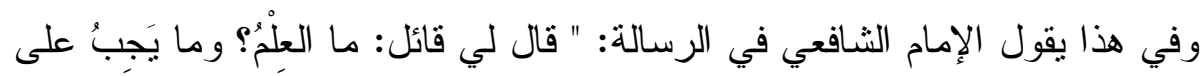

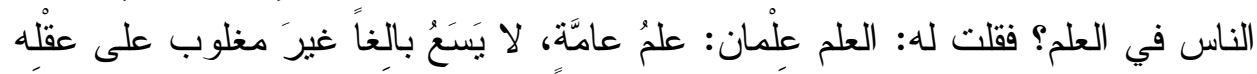

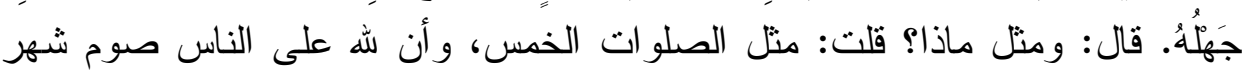

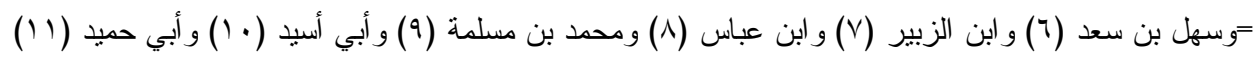

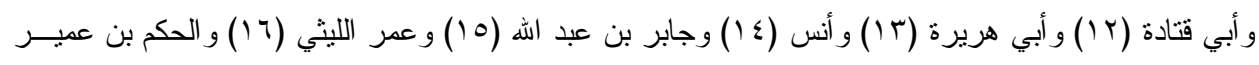

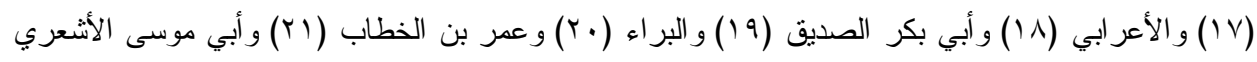

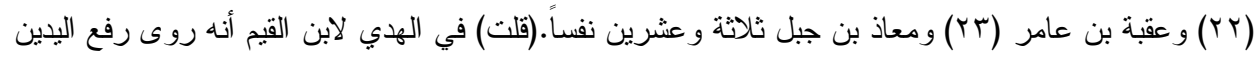

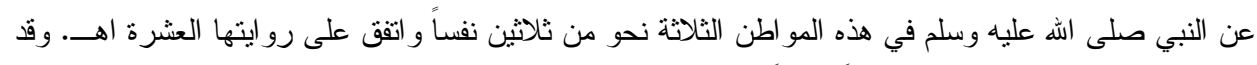

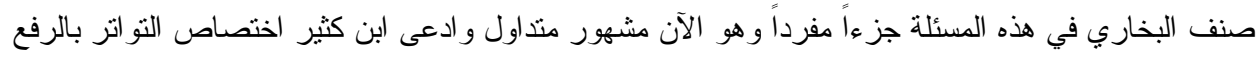

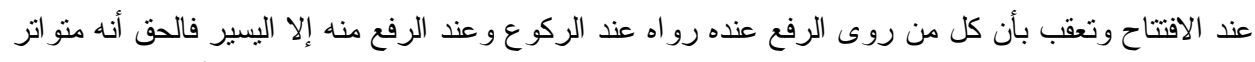

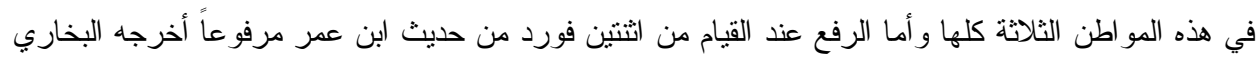

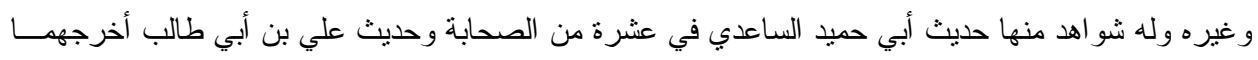

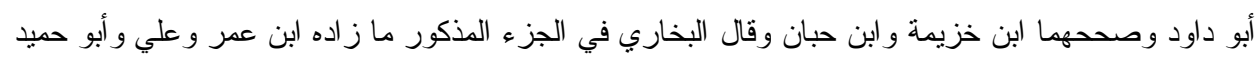

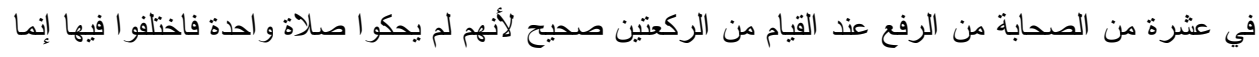

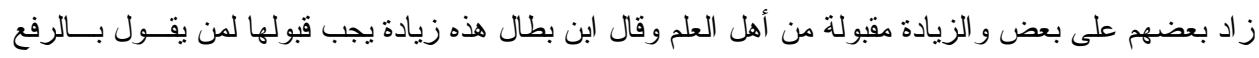

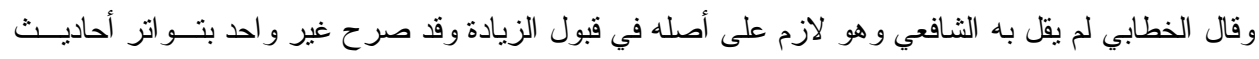

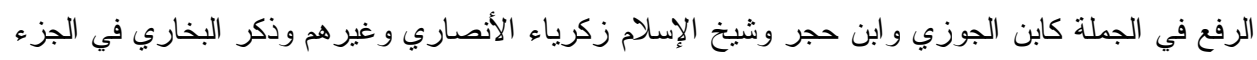

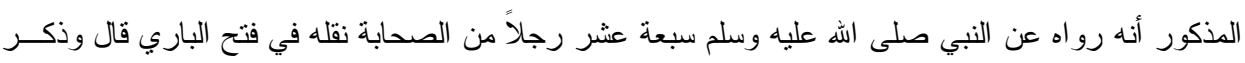

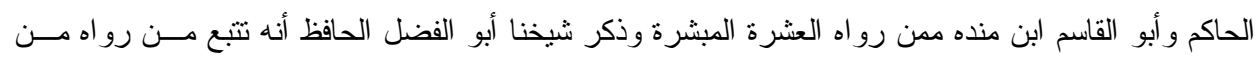

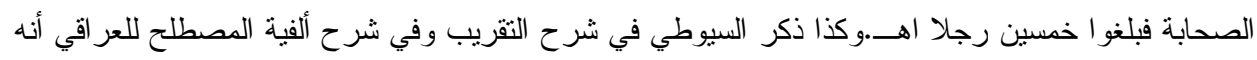

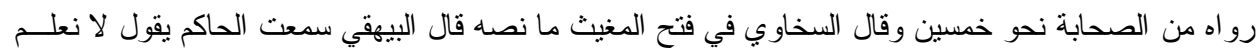

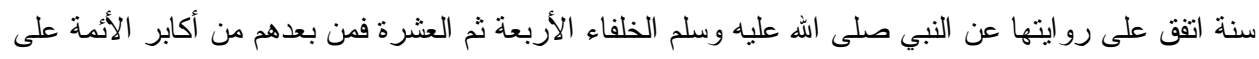

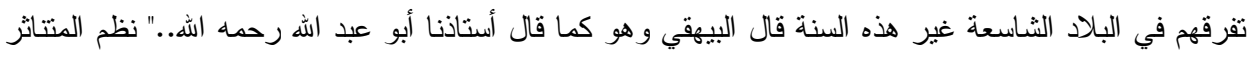




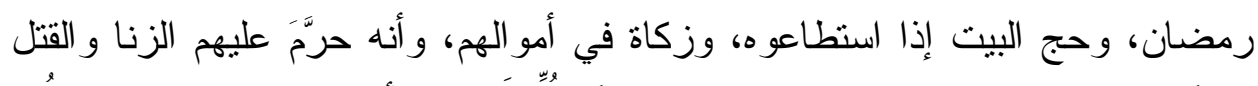

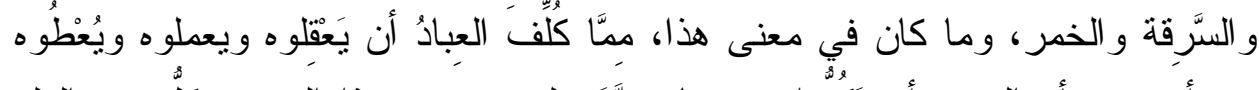

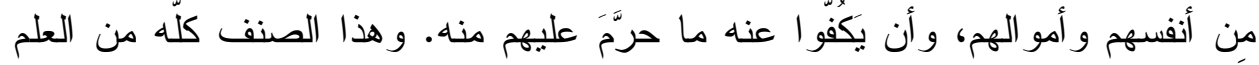

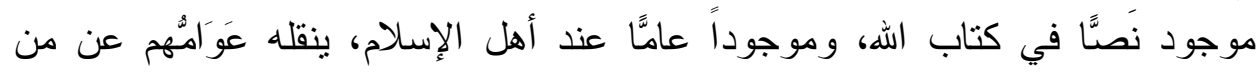

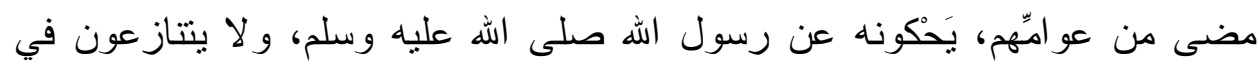

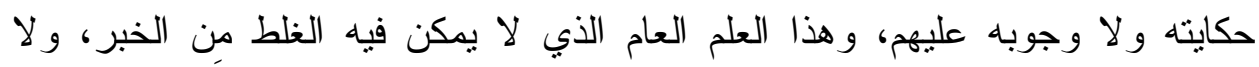

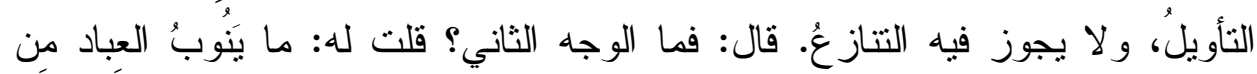

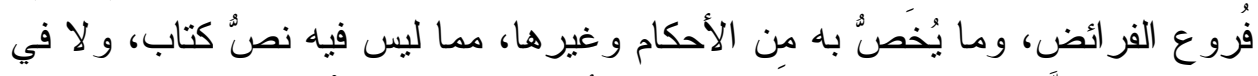

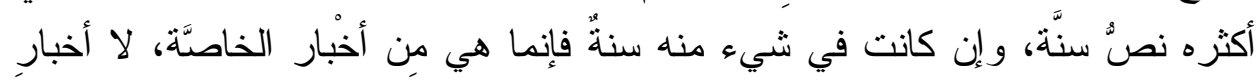

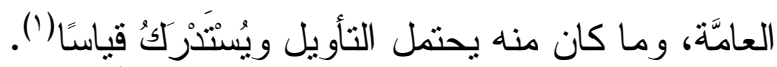
وقال ابن تيمية: "....التواتر ينقسم إلى: عام وخاص، فأهل التهل العلم بالحديث و والفقه قد

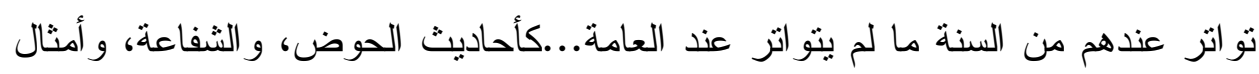

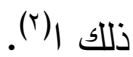

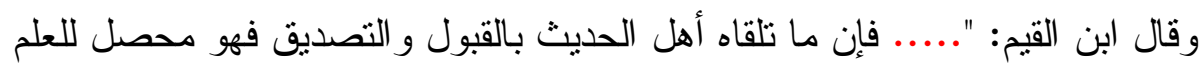

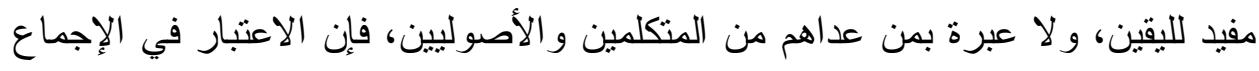

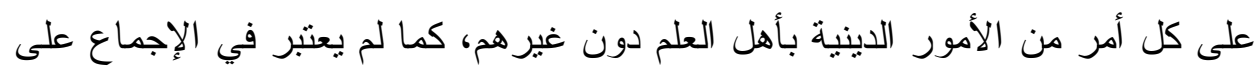

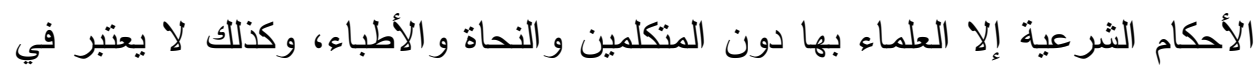

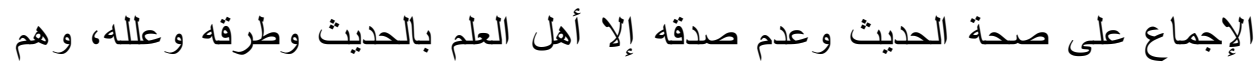

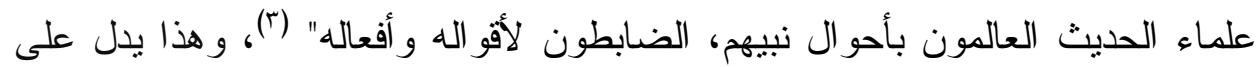

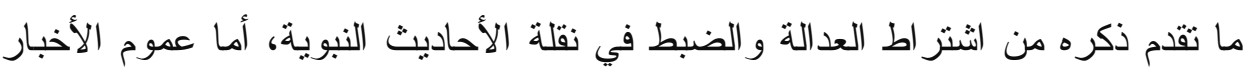

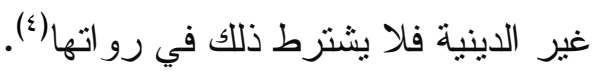

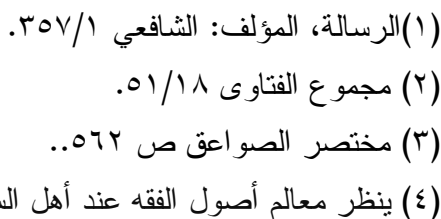

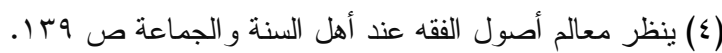




\section{المبحث السادس}

\section{اختلاف العلماء في وجود الخبر المتواتر}

اختلف العلماء في وجود الخبر المتواتز عن رسول الله صلى الله عليه وسلم،

$$
\text { وذهبوا في هذا الخلاف إلى ثلاثة مذاهب: }
$$

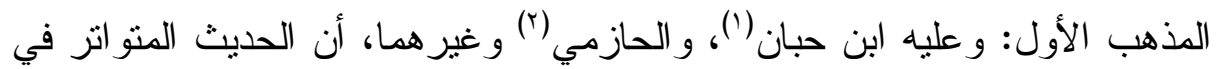
السنة المستوفي لشروط التواتر لا وجود له، و إنما الموجود منه هو الآحاد الذي قد يبلغ وفئ درجة الاستفاضة و الثهرة. المذهب الثاني: أن الحديث المتواتر في السنة نادر قليل يعز وجوده، وهو مذهب الحافظ ابن الصلاح حيث يقول في مقدمته: ومن سئل عن إير از مثال لذلك فيما يروى ونى

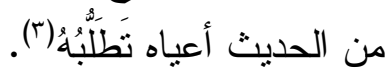
المذهب الثالث: وهو مذهب جمهور العلماء أن الحديث المنواتر في السنة النبوية له وجود كثثر، و أيد ذلك بأنه يوجد بالفعل أحاديث منواترة كثيرة في كتب الحديث المشهورة منل الكتب الستة و المسانيد و غير ها. ورد الجمهور على أصحاب المذهبين الأولين القائلين بعدم وجود المتواتر أو بعزة وجوده، بأن ما ادعوه إنما نشأ عن قلة اطلاع على كثرة الطرق، وأحوال الرجال

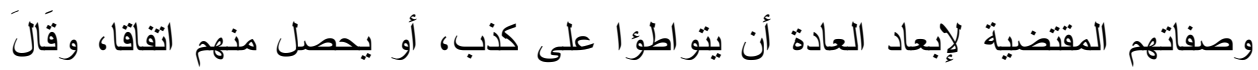

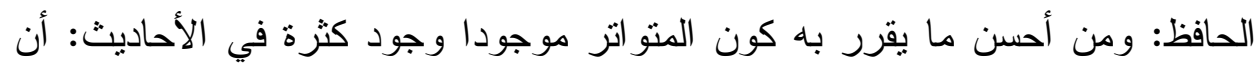

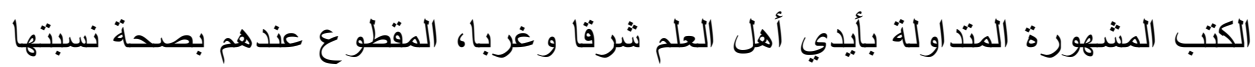
إلى مصنفيها، إذا اجتمعت على إخراج حديث، وتعددت طرقه تعددا تحيل العادة

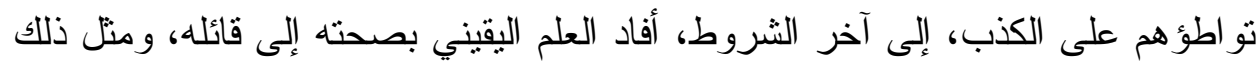

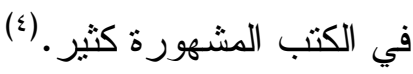

(1) قال في مقدمة صحيحه: " فأما الأخبار فإنها كلها أخبار آحاد" / 107 (107.

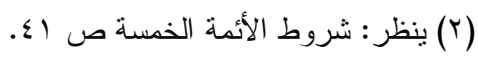

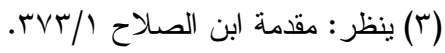

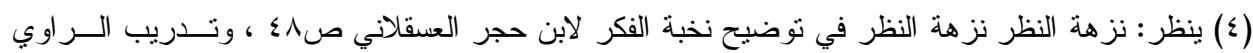


ويمكن أن بحمع بين هذه المذاهب الثاثلة بأن القائلين بعدم وجود الحديث المتــواتر

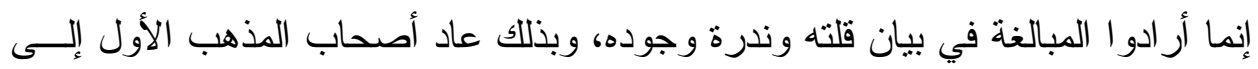

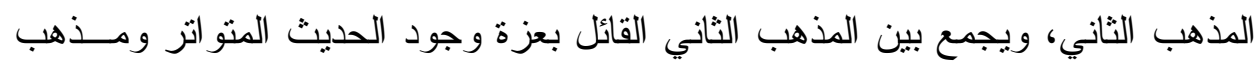

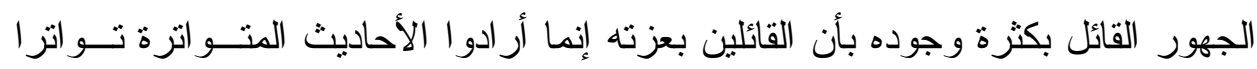

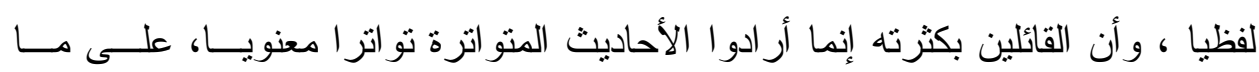
سيأتي بيانه في مبحث أقنام المنو اتز (').

\section{المبحث السابع}

\section{بيان نوع العلم الأي يُقيده الخبر المتواتر}

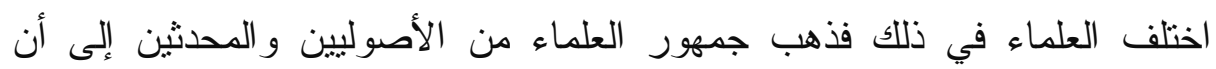

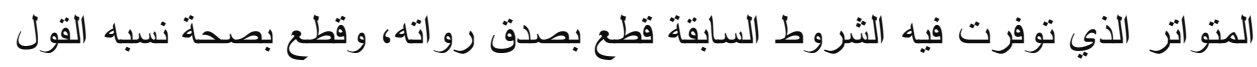

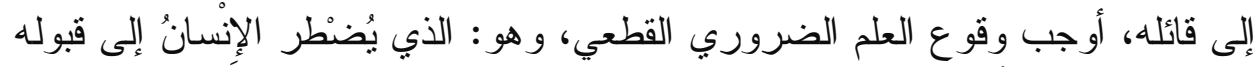

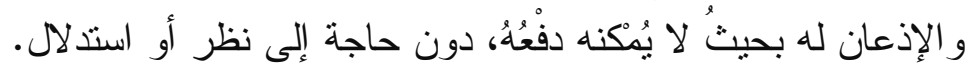
وذهب البعض إلى أنه علم نظري يتوقف على الفكر و النظر الذي هو ترتيب أمور

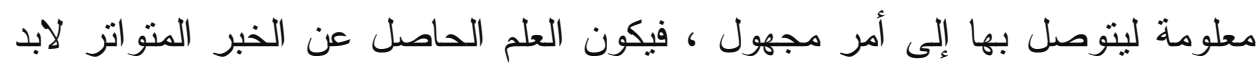

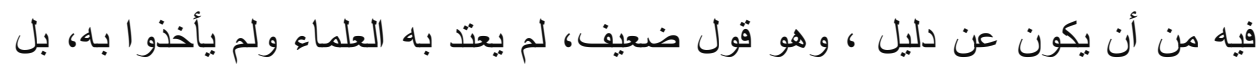

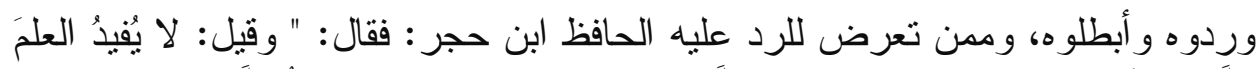

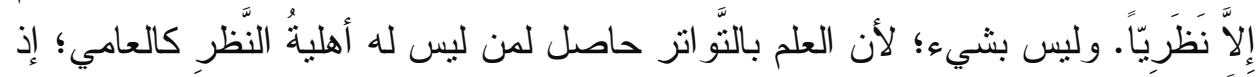

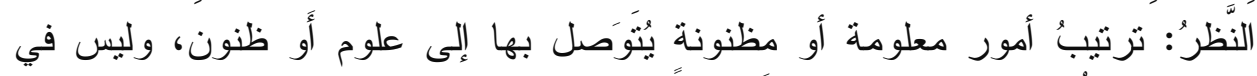

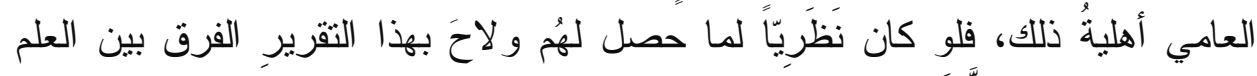

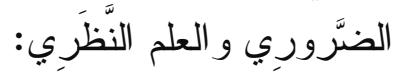

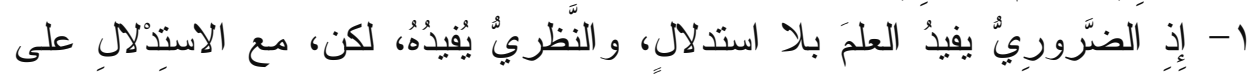
الإفادة.

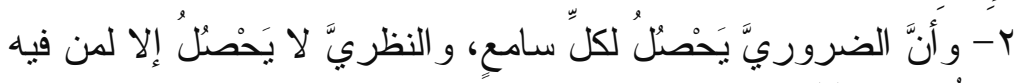

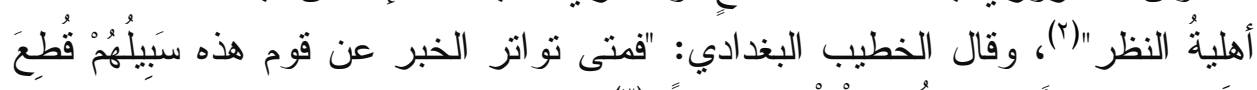

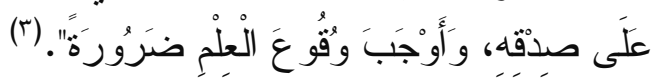




\section{المبحث الثامن}

حكم قبول الخبر المتواتر والعمل به، وأهمية معرفته، وحكم منكره

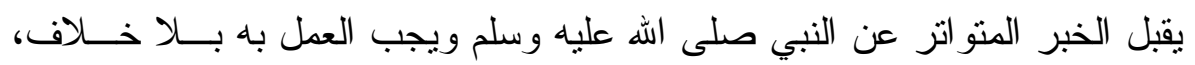
متى توفرت فيه الثروط السابقة؛ لأنه يفيد العلم اليقيني القاطع الجازم بثبوت نسبته إلى ولى لئل

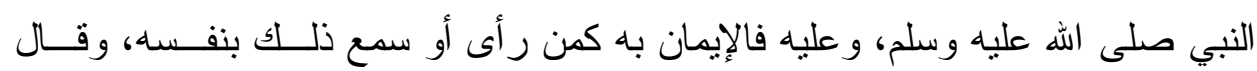

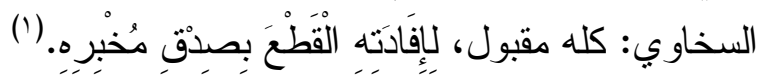

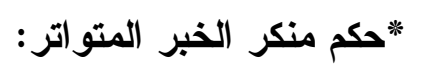

ذهب جمهور العلماء من الأصوليين و المحدثين كما تقدم بيانه إلى أن الخبر المنو اتز الذي توفرت فيه شروط التوانر قطع بصدق رواته، وقطع بصحة نسبه القول

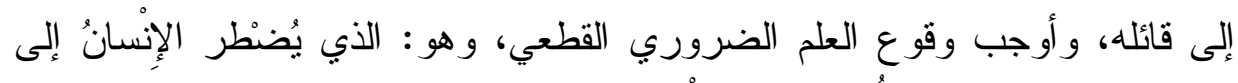

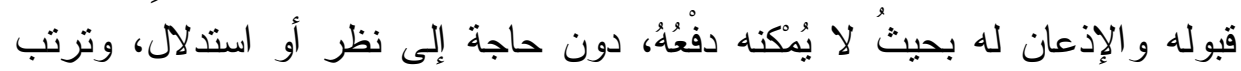

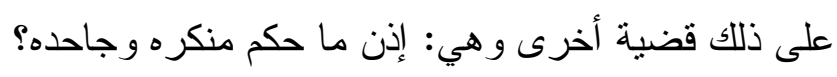

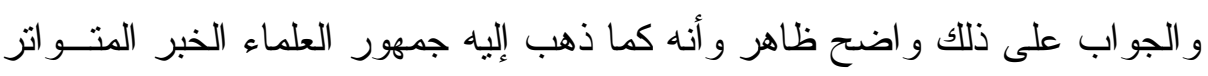
يفيد العلم اليقيني القطعي الضروري، ومقطوع بصحة نسبته إلى رسول الله صــلـى الله

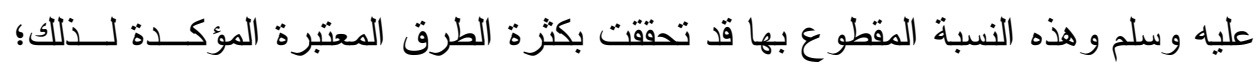

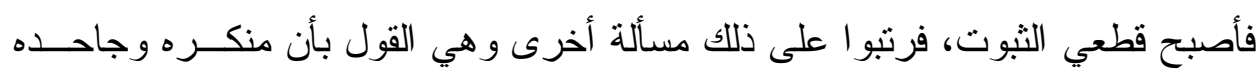

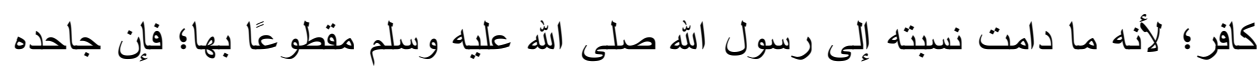

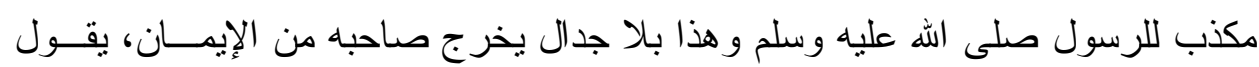

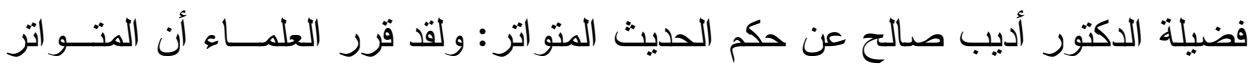

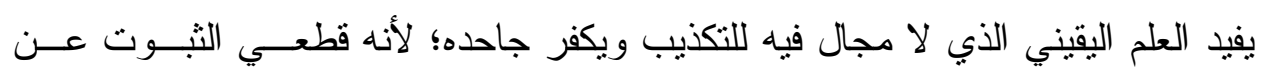

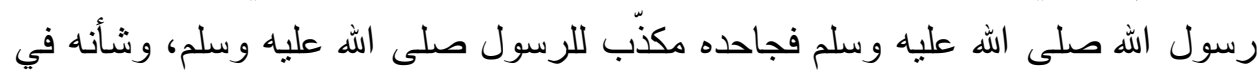
إفادة العلم شأن ما يفيده الحس بالمشاهدة وغير هـا(ب).

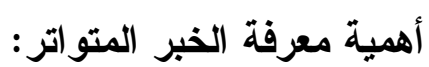

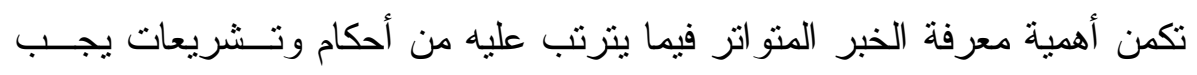

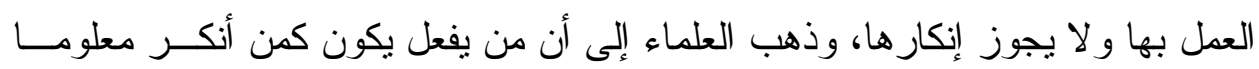




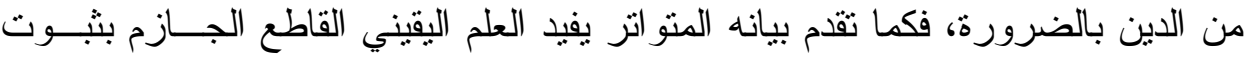

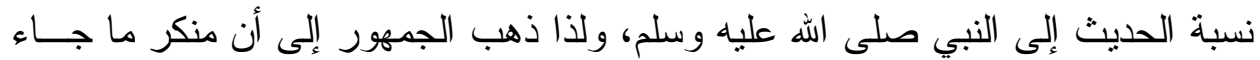
به كافر

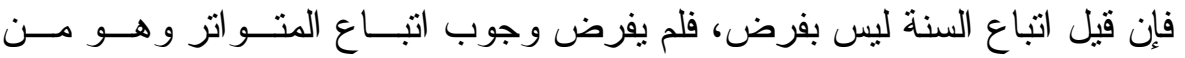

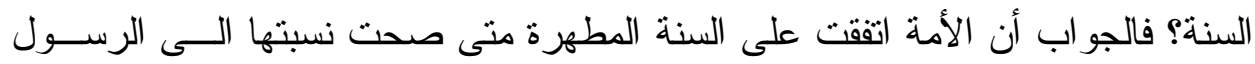

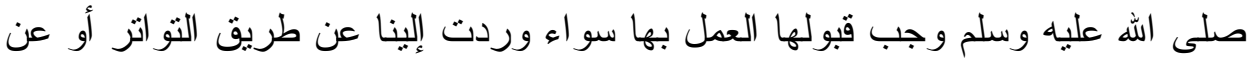

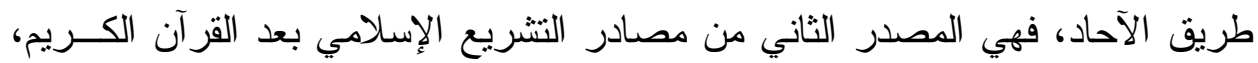

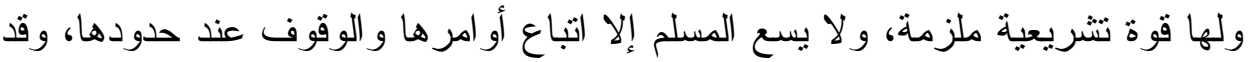

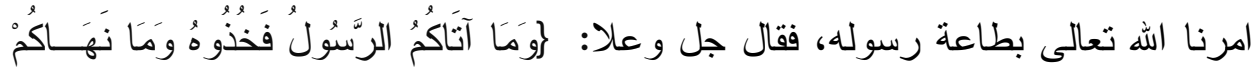

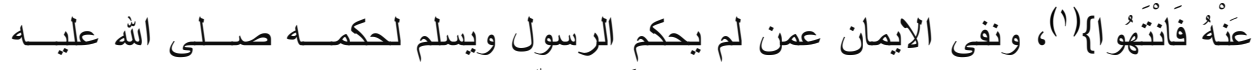

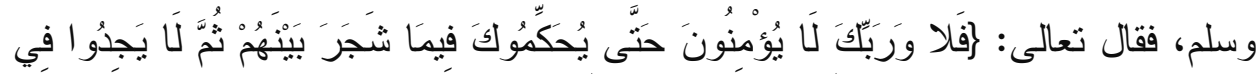

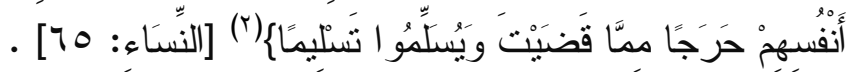

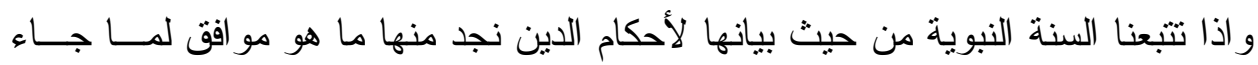

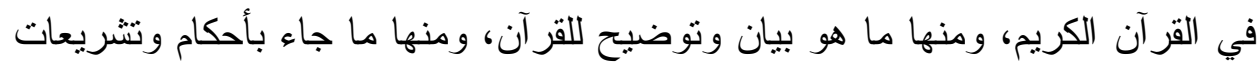

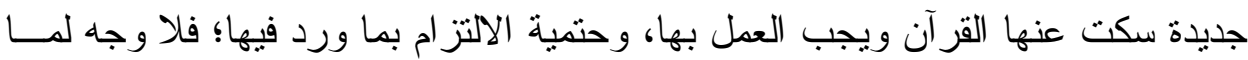

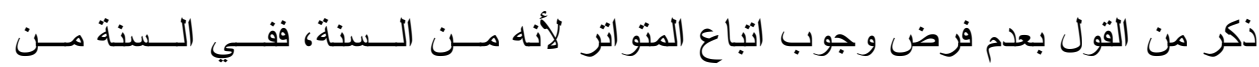

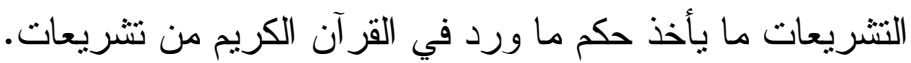

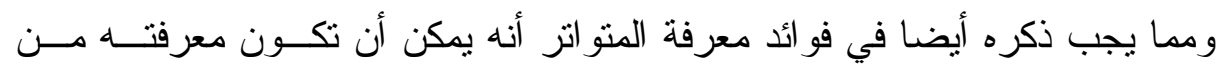

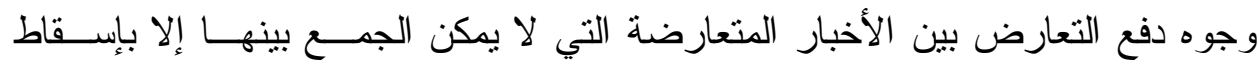
أحدهما، فحينئذ يقدم الخبر المنو اتر على الآحاد، وهذه فائدة جليلة.

(1) سورة الحشر : آية V. 


\section{المبحث التاسع}

\section{في الثبه الواردة على المتواتز وردها( (1)}

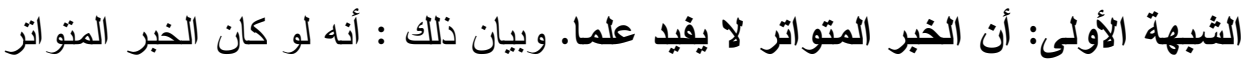

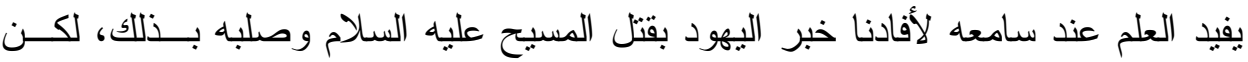

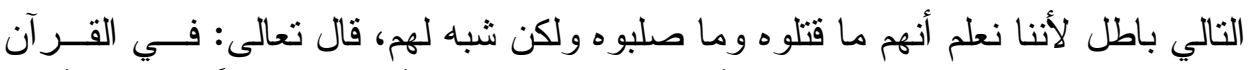

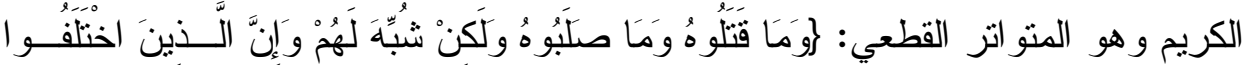

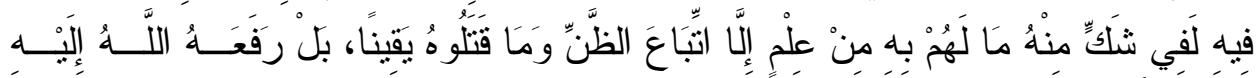

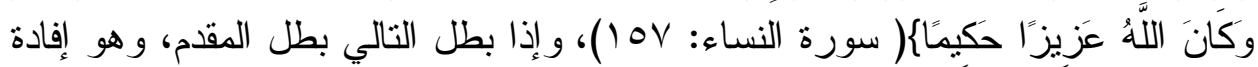
الخبر المتوانز العلم عند سامعه.

ويجاب عن ذللك بأن خبر اليهود بقتل المسيح وصلبه لم يكن منو اتر ا ولذلك لم يفــنـا علما؛ لأن الرواة في أول السند ووسطه لم يبلغو المن الكثرة حدا يحيل العقل معها عـادة

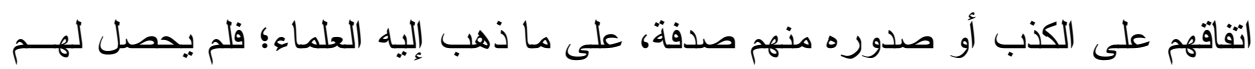
شرط التواتر r)

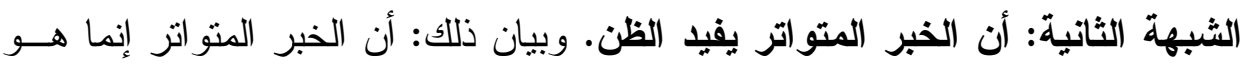

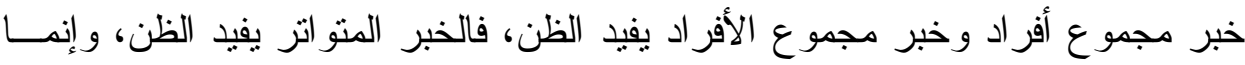

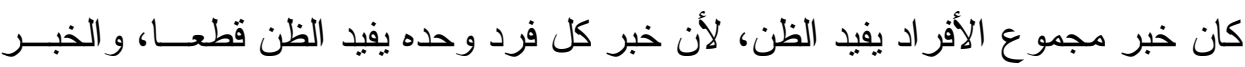
المفيد للظن إذا ضم إلى خبر آخر مفيد للظن أفاد ظنا.

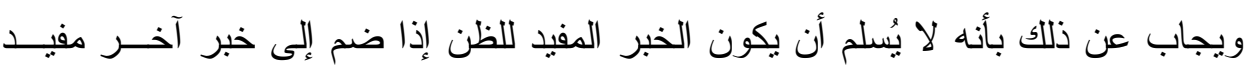

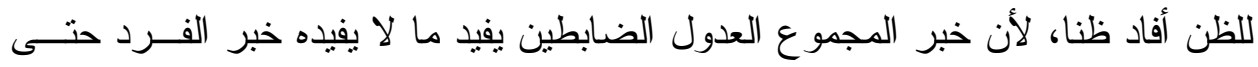

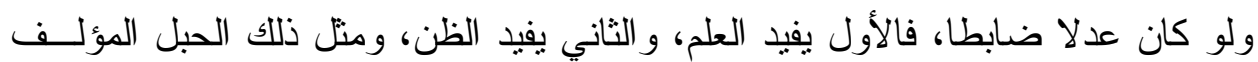

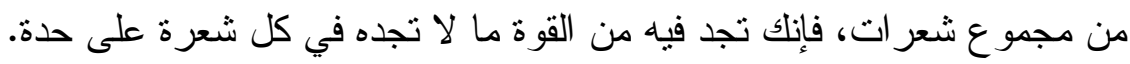

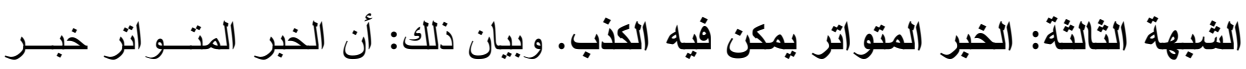

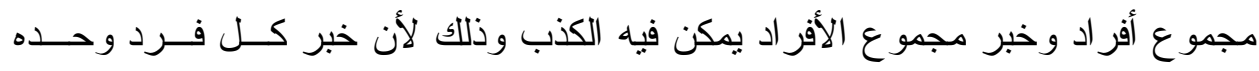

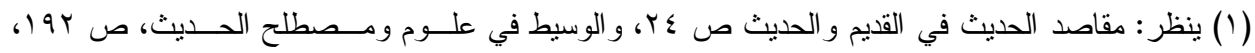

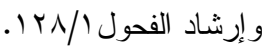

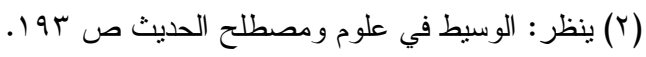


يمكن فيه الكذب، وضم الخبر الذي يمكن فيه الكذب إلى خبر آخر يمكن فيه الكذب يفيد أن خبر المجموع يمكن فيه الكذب.

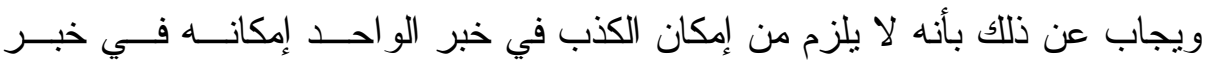

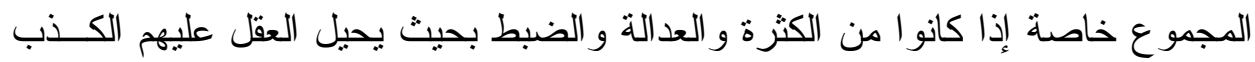
عادة بقصد أو بغير قصد.

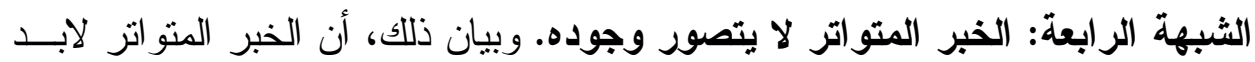

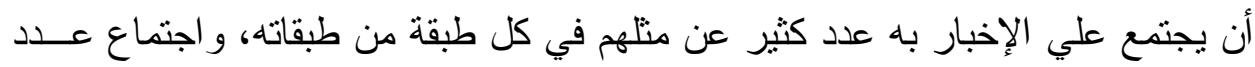

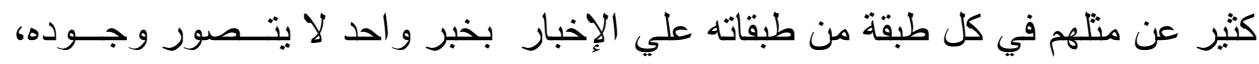

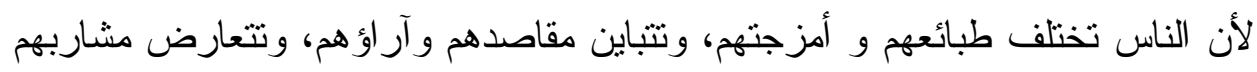
و اغر اضهم ولذلك لا يتصور اتفاقهم علي الإخبار بالخبر الواحد.

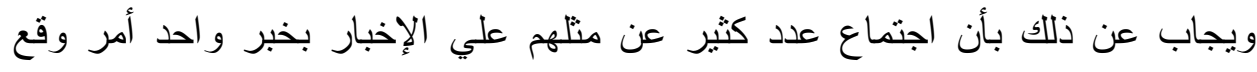
ويقع بالفعل كثير ا في دنيا الناس فنشاهد اتفاق العدد الكثير دن الناس على الإنى الأخبار بكثير من الأشياء مع اختلاف طبائعهم و أمزجتهم، وتتباين مقاصدهم وآراؤهم، ونتائي أماكنهم وذلك كاتفاقه على الإخبار بوجود الكثير من المدن و البلدان التي لم نشاهدها،

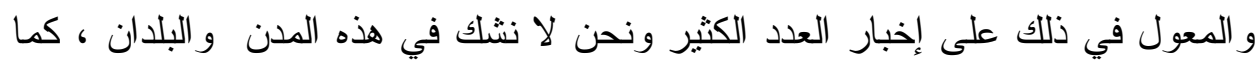

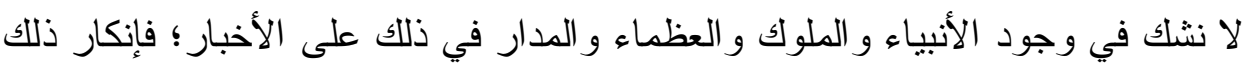
مكابرة و عناد.

الثبهة الخامسة: الخبر المتواتر يمكن أن يقع التناقض فيه. وبيان ذلك أن الخبر

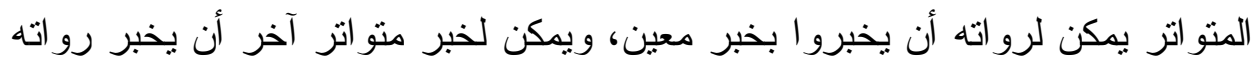
بخبر آخر معين يناقض الخبر الأول فيؤدي ذللك إلى أن الخبر المتو اتر يمكن أن يقع التناقض فيه. و الجو اب: أن هذا فرض محال؛ فإنه متى أخبر جمع تو افرت فيه شروط التواتر بـشيء

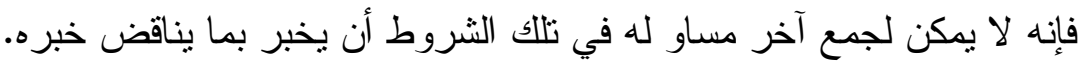
أثهر المصنفات في الأخبار المتواترة: 1- الأزهار المتناثرة في الأخبار المتواتزة: لجال الأبرة الدين عبد الرحمن بن أبي بكر السيوطي، المتوفى سنة إحدى عشرة وتسعمائة، والكتاب كما ذكر المؤلف في لإني مقدمته جرده من كتاب آخر له، قال: "فإني جمعت كتابا سميته "الفو ائد المتكاثرة في وني 
الأخبار المتواترة" - لم أجده مطبو عا- أوردت فيه ما رواه من الصحابة عشرة

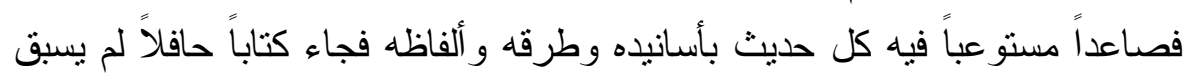

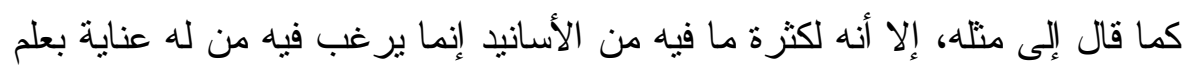

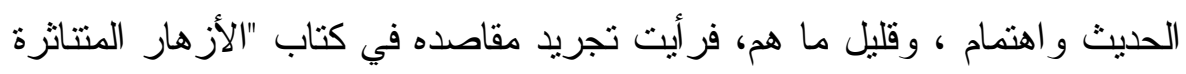

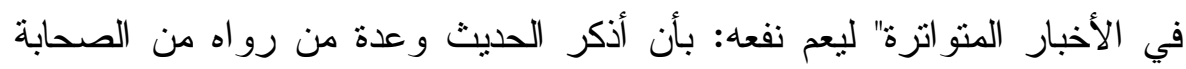
مقروناً بالعزو إلى من خرجه من الأئمة المشهورين، وهو مرتب على لئى الأبواب

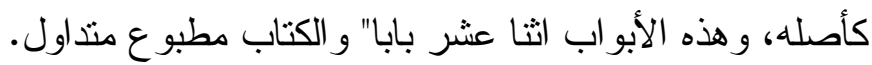

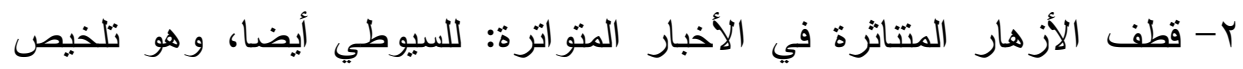

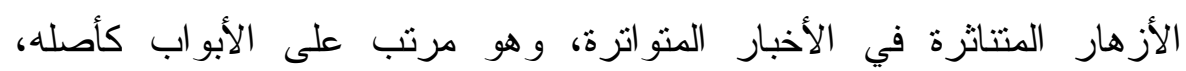
و الكتاب مطبو ع متداول.

r- اللآلىئ المنتاثرة في الأحاديث المتواترة: لثمس الدين مسند الثام في عصره أبي عبد

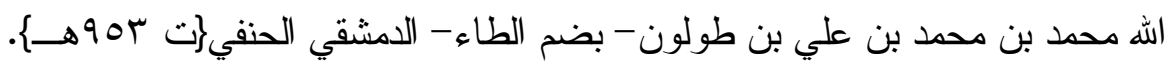

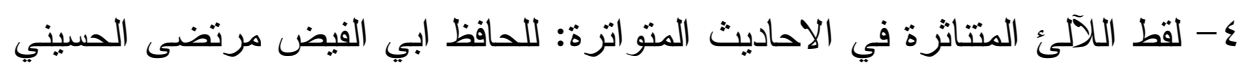
الزبيدي،\}ت ه . 1 اهـــ، لخص فيه كتاب ابن طولون، و الكتاب مطبوع.

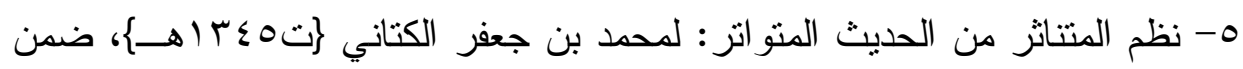

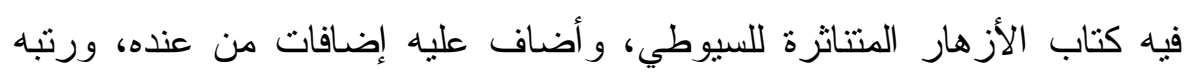

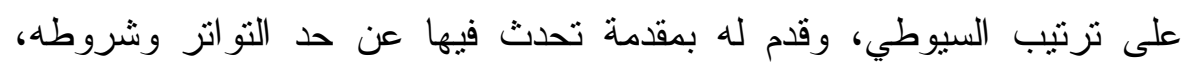

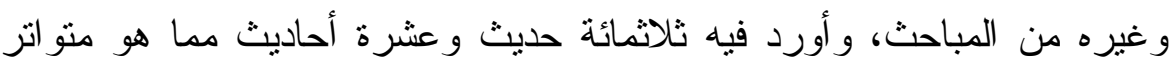

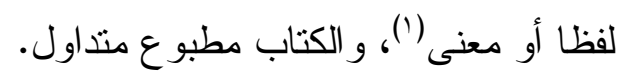

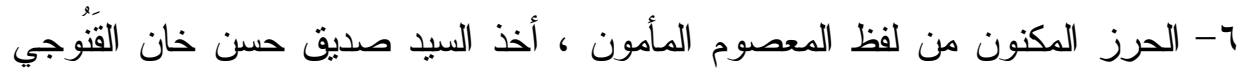

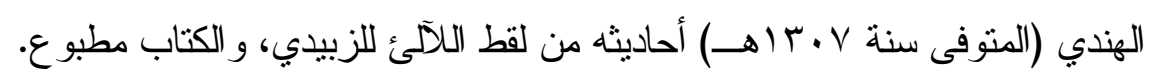

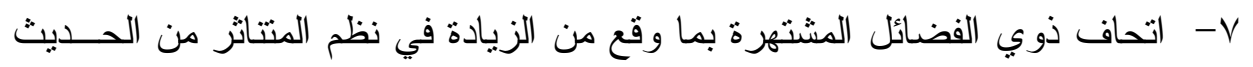

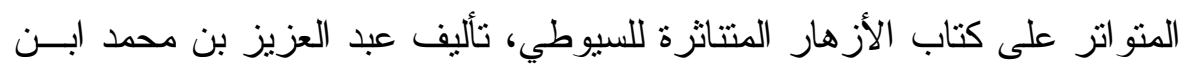
صديق الغماري، و غير ذلك.

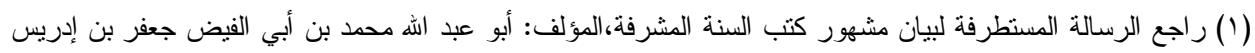

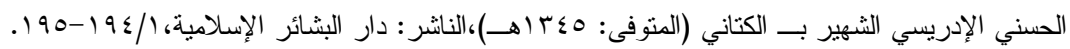




\section{الخاتمة}

الحمد لله الذي بنعمته تتم الصالحات، وبعد:

فأسأل الله سبحانه وتعالى أن أكون قد وفقت إلى إلقاء الضوء على بعض الهـ المباحث الهامة المتعلقة بالخبر الموتز، ووفقت إلى الإجابة الصحيحة عم سألتتي عنه السائلة الهاء

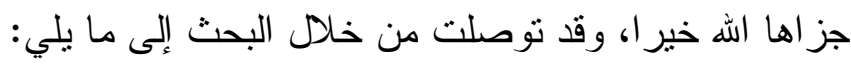

ا- أن الكثير من الأصوليين عند حديثهم عن شروط الخبر المنوانر لم يفرقوا في مالي ذلك بين الأخبار الدينية و الأخبار الدنيوية. r- هناك فرق بين طرق ثثوت الأخبار الدنيوية والأخبار الدينية عن رسول الله

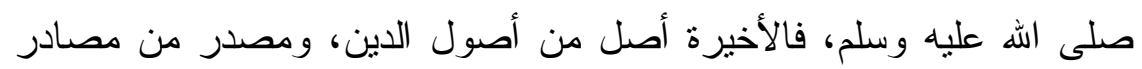
النتريع ؛لها شروطها الخاصة لقبولها، و لا تقبل بدونها.

r- يجب أن ينوفر في الأخبار الدينية شروط ثبوتها وقبولها المتفق عليها عند

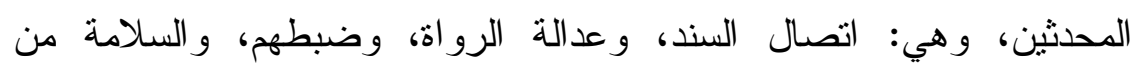

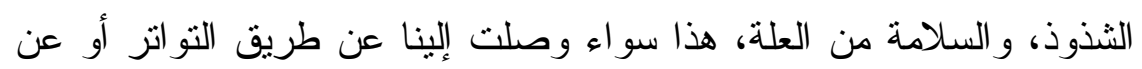
طريق الآحاد.

ع - أرى أن ما ذكره الأصوليون من عدم الثتر اط العدالة في رواة الخبر إنما هو

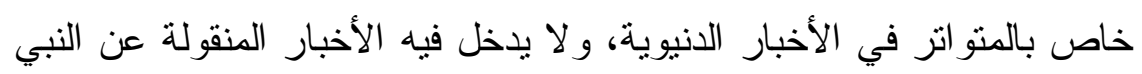
صلى الله عليه وسلم. ه- أن الخبر إذا تو افرت فيه شروط التواتر، مع شروط قبوله عند المحدثين فهو أصح أنو اع الأخبار المقبولة، ويقدم على غيره من الصحيح.

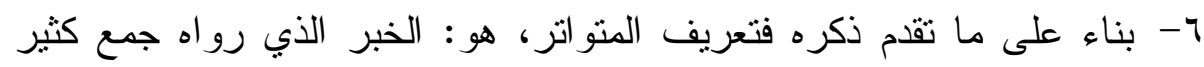

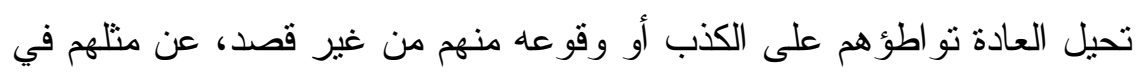

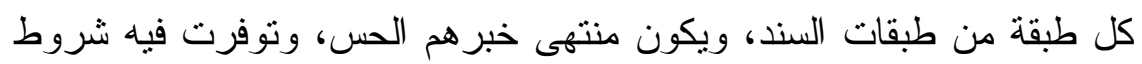
القبول عند المحدثين، ويصحب طنبعان خبر هم إفادة العلم بنفسه لسامعه. V- الخبر المتواتر متى نوفرت فيه شروط التواتر و القبول فإنه يفيد العلم اليقيني القطعي الضروري، ومقطوع بصحة نسبته إلى رسول الله صلى الله عليه وسلم وهذه النسبة المقطوع بها قد تحققت بكثرة الطرق المعتبرة المؤكدة لذلك. 
1- الخبر المستكمل لشروط التواتر السابقة قطعي الثبوت عنه صلى الله عليه وسلم؛ فإذا دل مضمون هذا الخبر على أمر معلوم من الدين بالضرورة فئرة فإن منكره وجاحده كافر؛ لأنه ما دامت نسبته إلى رسول الله -صلى الله على عليه

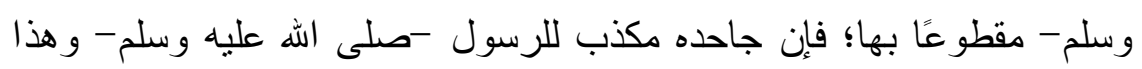
بلا جدال يخرج صاحبه من الإيمان. 9- الخبر إذا لم تتو افر فيه الشروط السابقة، ولم يكن مضمونه مدا علم من من الإين بالضرورة فلا يكفر منكره. • 1- عموما الخبر إذا ثبت عن رسول اله صلى الله عليه وسلم بأن توفرت فيه هُه

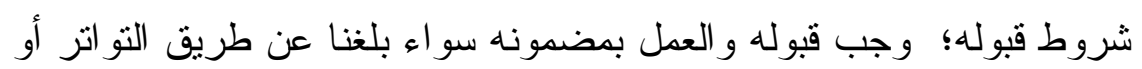

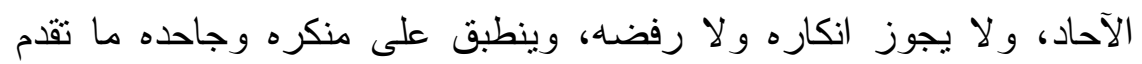
ذكره في حكم منكر المنو اتر . وآخر دعوانا أن الحمد لله رب العالمين،

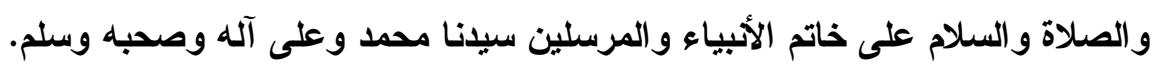




\section{المصادر والمر اجع}

1- الإبهاج في شرح المنهاج ((منهاج الوصول إلي علم الأصول للقاضي البيضاوي المتوفي

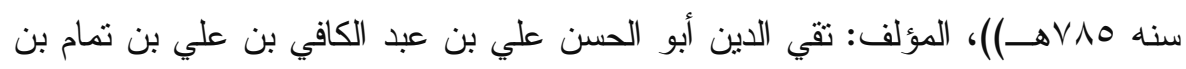

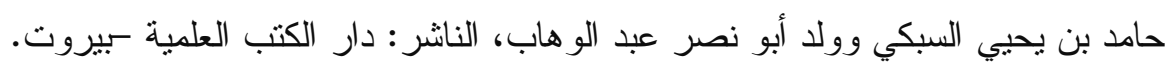

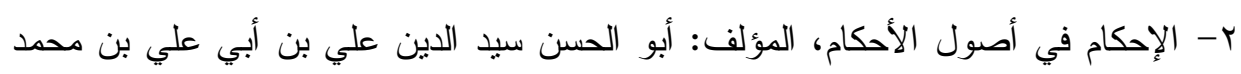

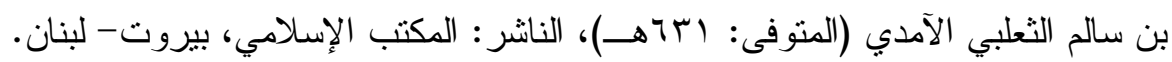
r- الإحكام في أصول الأحكام، المؤلف: أبو محمد علي بن أحمد بن سعيد بن حزم الأندلسي

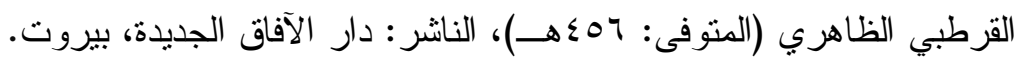

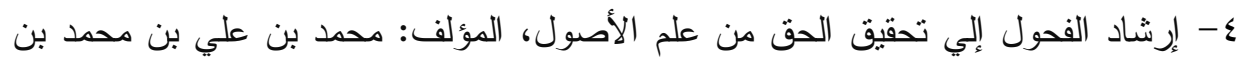

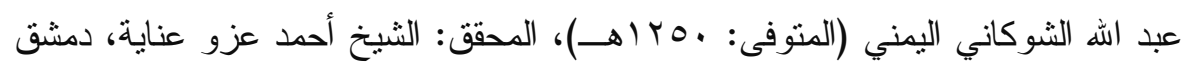
- كفر بطنا، الناشر : دار الكتاب العربي. ه- الاستيعاب في معرفة الأصحاب، المؤلف: أبو عمر يوسف بن عبد الله بن محمد بن عبد

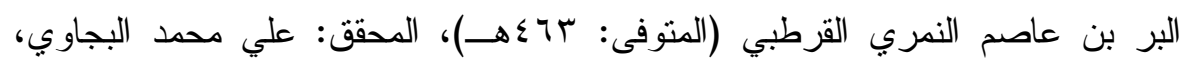
الناشر : دار الجيل، بيروت.

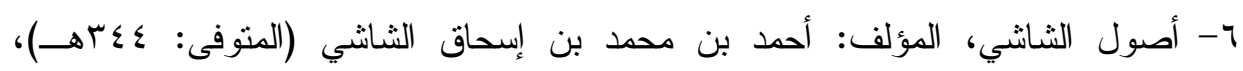
النانشر : دار الكتاب العربي - بيروت.

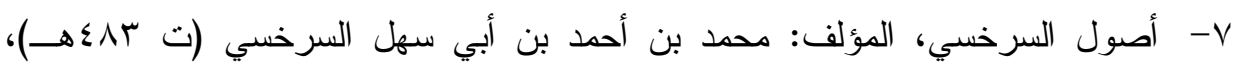

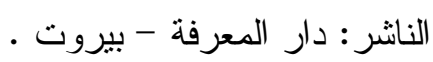

^- البحر المحيط في أصول الفقه، المؤلف: محمد بن عبد الله بن بهادر الزركثي (المتوفى:

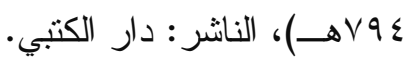

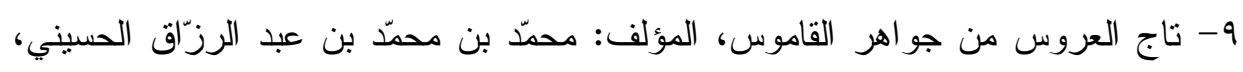

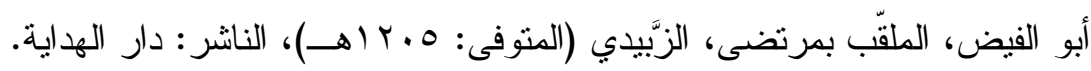

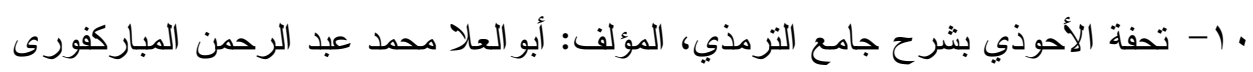
(ت إهب اهـ) ط: دار الكتب العلمية، بيروت.

الا-تدريب الر اوي في شرح تقريب النواوي، المؤلف: عبد الرحمن بن أبي بكر، جلاد الدين

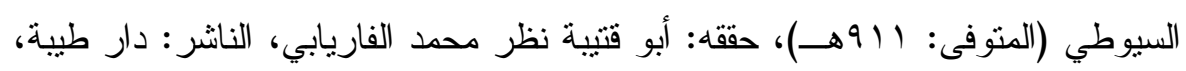

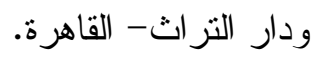


r ا- التقييد و الإيضاح شرح مقدمة ابن الصلاح، المؤلف: أبو الفضل زين الدين عبد الرحيم

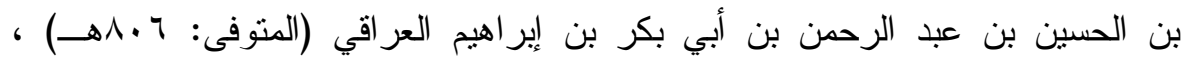
الناثر : المكتبة السلفية بالمدينة المنورة.

rا- تهذيب التهذيب، المؤلف: أبو الفضل أحمد بن علي بن محمد بن أحمد بن حجر

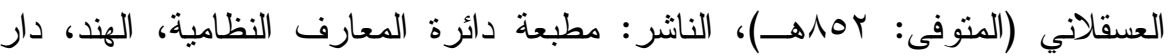
الكتب العلمية.

ع ا-تقريب التهذيب، المؤلف: أبو الفضل أحمد بن علي بن محمد بن أحمد بن حجر العسقلاني (المتوفى: 10 10هـ)، الناشر : دار الرشيد - سوريا. 10-نوجيه النظر إلى أصول الأثر، المؤلف: طاهر بن صالح (أو محمد صالح) ابن أحمد بن موهب، السمعوني الجز ائري، (ت مبس اهــ)، مكتبة المطبو عات الإسلامية - حلب.

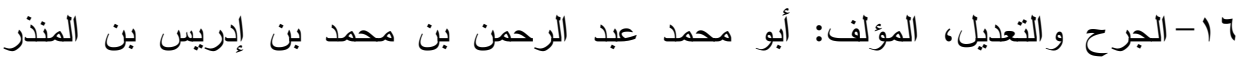

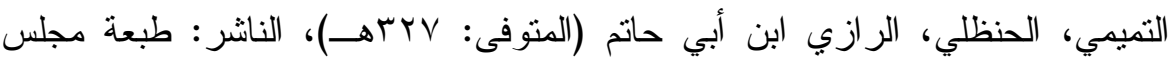
دائرة المعارف العثمانية - بحيدر آباد الدكن - الهند، دار إحياء التزاث العين العربي.

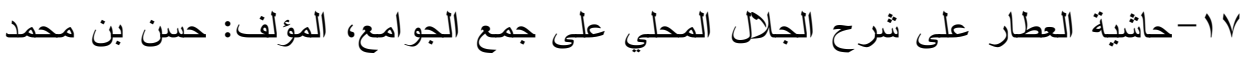

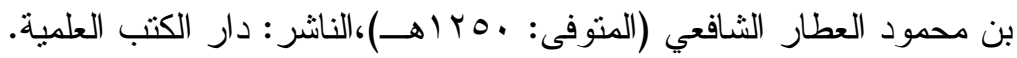

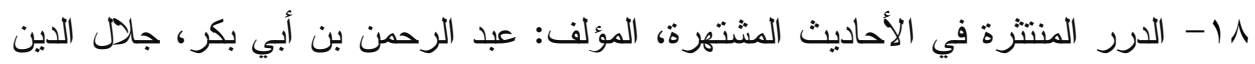
السيوطي (المتوفى: 119 (9ه)، تحقيق: الدكتور محمد بن لطفي الصباغ، الناشر : عمادة شؤون المكتبات - جامعة الملك سعود، الرياض. 9 1 - الدفاع عن السنة، النانثر : جامعة المدينة العالمية.

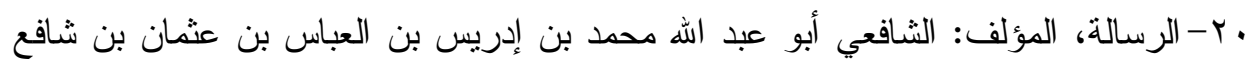

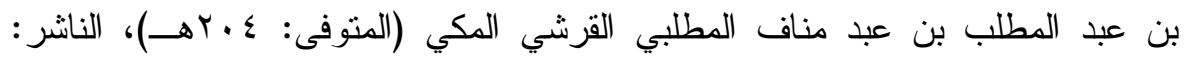
مكتبه الحلبي، مصر • بأن اب- الرسالة المستطرفة لبيان مشهور كتب السنة المشرفة، المؤلف: أبو عبد اله محمد بن

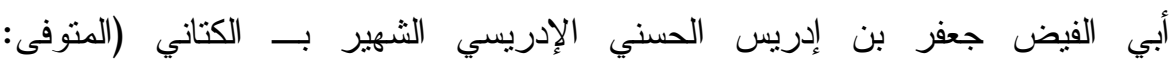

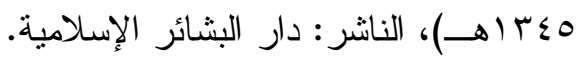
r r-روضة الناظر وجنة المناظر في أصول الفقه على مذهب الإمام أحمد بن حنبل، المؤلف:

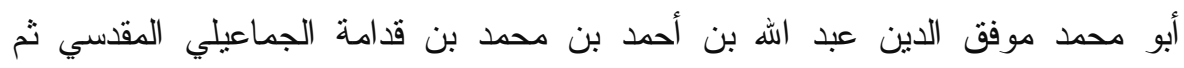


الدمشقي الحنبلي، الثهير بابن قدامة المقدسي (ت.ب7هـ)، الناشر : مؤسسة الريّان ل للطباعة و النشر

بr-سير أعلام النبلاءـ، المؤلف : شمس الدين أبو عبد اله محمد بن أحمد بن عثمان بن

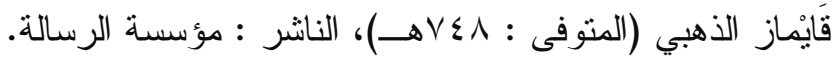
ـ ؟- شرح تتقيح الفصول، المؤلف: أبو العباس شهاب الدين أحمد بن إدريس بن عبد الرئ الرحمن

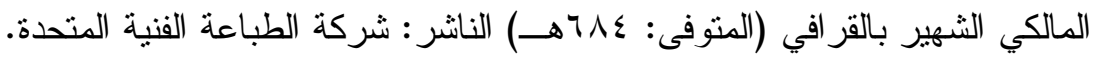
هr- شرح نخبة الفكر في مصطلحات أهل الأثر، المؤلف: علي بن (سلطان) محمد، أبو

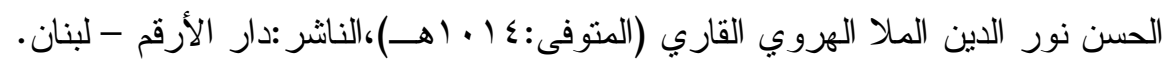

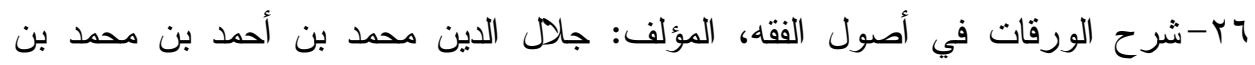
إبر اهيم المحلي الثافعي (المتوفى: ؟1 1هــ)، الناشر : جامعة القدس، فلسطين. r ^ץ-الصحاح تاج اللغة وصحاح العربية، المؤلف: أبو نصر إسماعيل بن حماد الجوهري

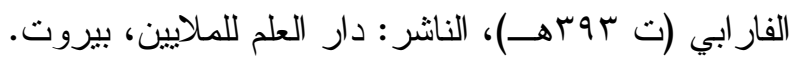

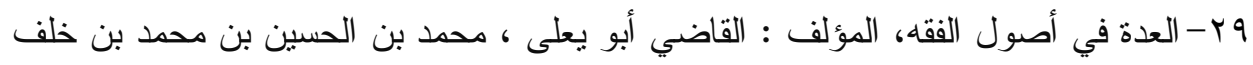

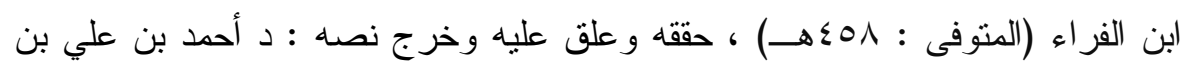

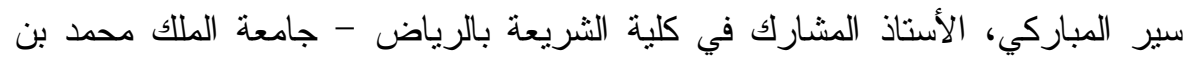

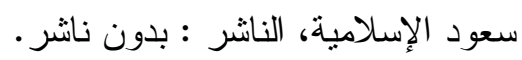
• ץ-غاية الوصول في شرح لب الأصول، المؤلف: زكريا بن محمد بن أحمد بن زكريا

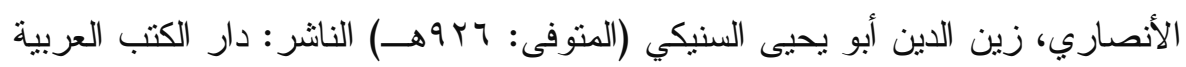
الكبرى، مصر (أصحابها: مصطفى البابي الحلبي و أخويه).

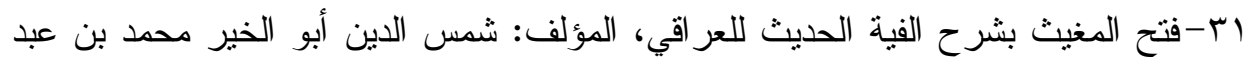

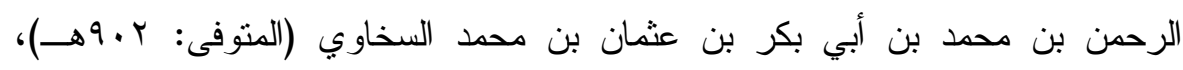

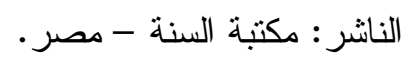

rr- الفتاوى الكبرى لابن تيمية، تقي الدين أبي العباس أحمد بن عبد الحليم بن عبد السلام بن

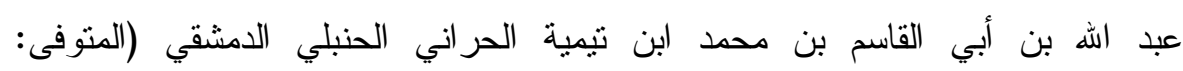

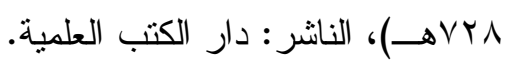


rr- القاموس المحيط، المؤلف: مجد الدين أبو طاهر محمد بن يعقوب الفيروزآبادى (المتوفى: VI V Vه)، تحقيق: مكتب تحقيق التزراث في مؤسسة الرسالة، الناشر : مؤسسة

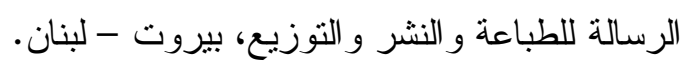

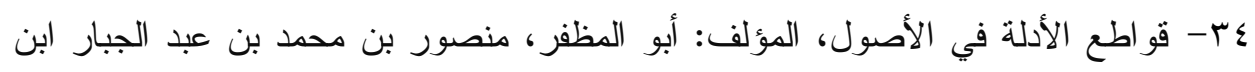

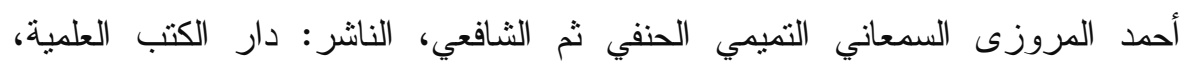
بيروت، لبنان.

هب- قو اعد التحديث من فنون مصطلح الحديث، المؤلف: محمد جمال الدين بن محمد سعيد

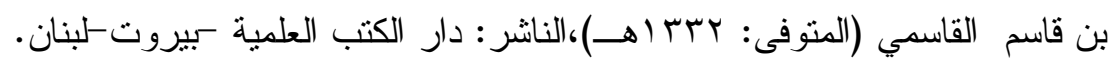

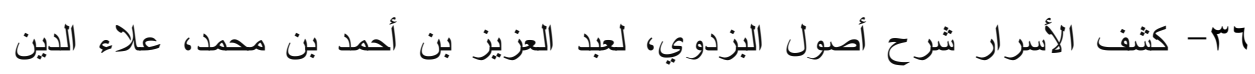

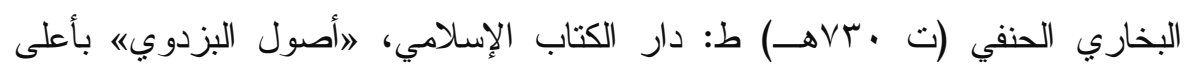
الصفحة يليه- مفصو لا بفاصل - شرحه 》كثف الأسر ار "لعلاء الدين البخاري.

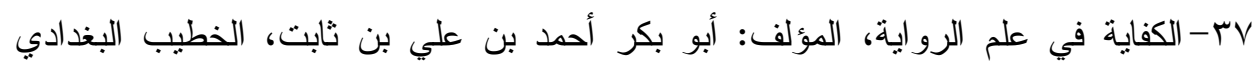

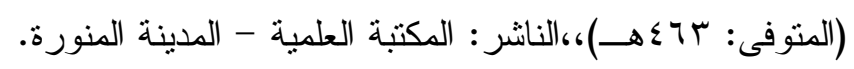
مبץ- لسان العرب، المؤلف: محمد بن مكرم بن على، أبو الفضل، جمال الدين ابن منظور

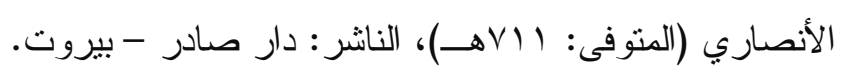

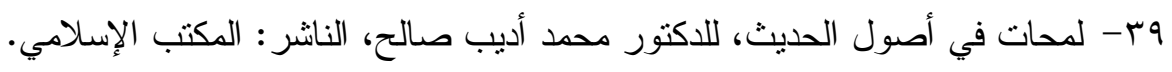

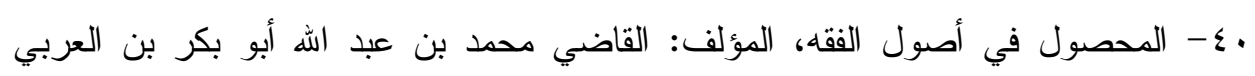

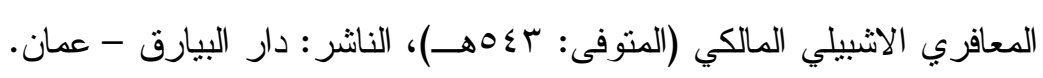

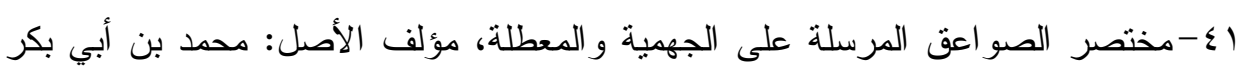

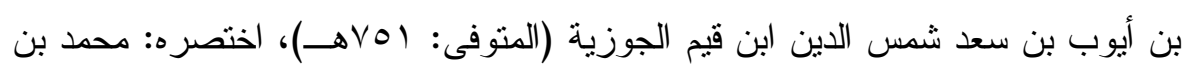

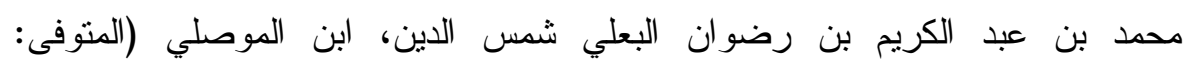

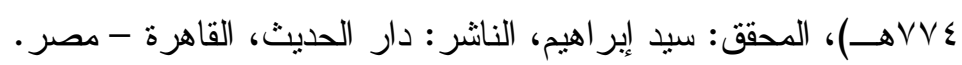

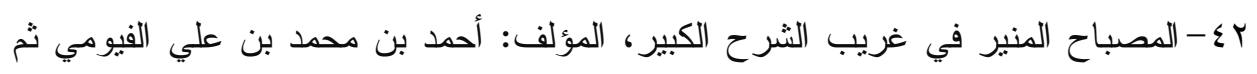

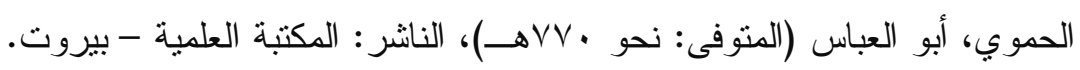

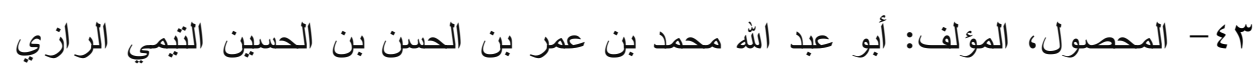

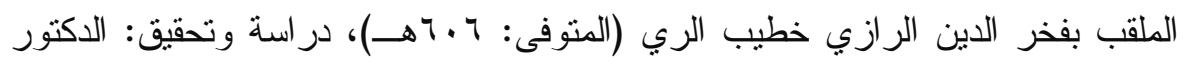
طه جابر فياض العلو اني، الناشر : مؤسسة الرسالة. 
؟ - المحكم و المحيط الأعظم، المؤلف: أبو الحسن علي بن إسماعيل بن سيده المرسي

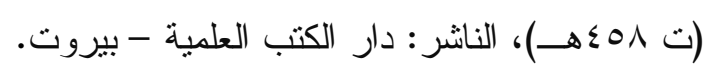

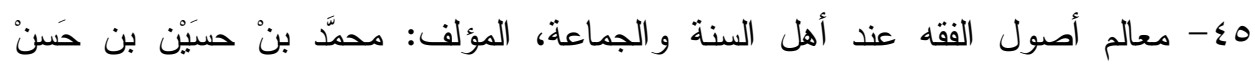

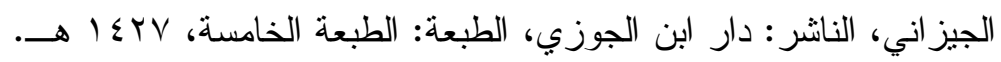

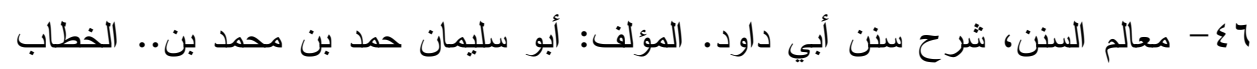

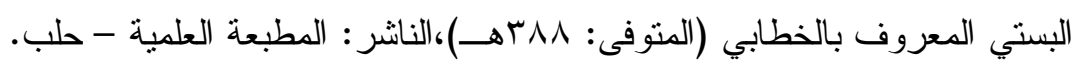
V V - المعتمد في أصول الفقه، المؤلف: محمد بن علي الطيب أبو الحسين البَصْري المعتزلي

$$
\begin{aligned}
& \text { (المتوفى: بr؟هــ)، الناشر : دار الكتب العلمية - بيروت. } \\
& \text { ^ــ - مقاصد الحديث في القديم و الحديث }
\end{aligned}
$$

9 - مقدمة ابن الصلاح= معرفة أنواع علوم الحديث، المؤلف: عثمان بن عبد الرحمن، أبو

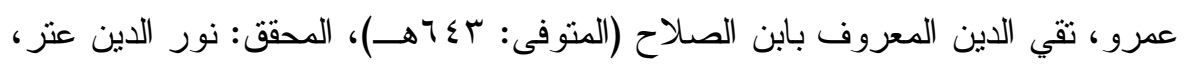
الناشر : دار الفكر - سوريا، دار الفكر المعاصر - بيروت باين.

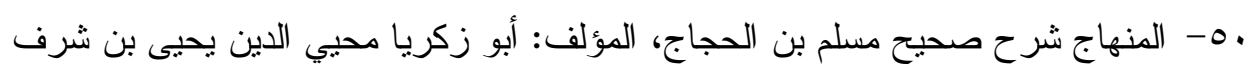

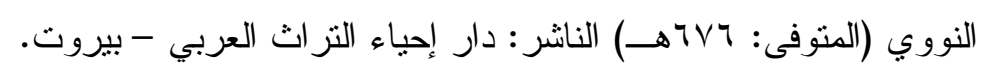

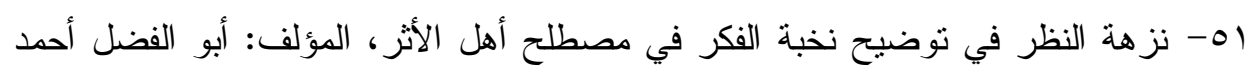

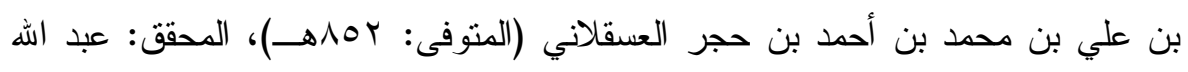

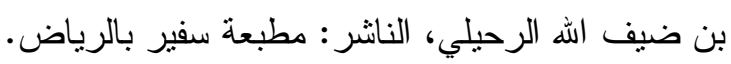

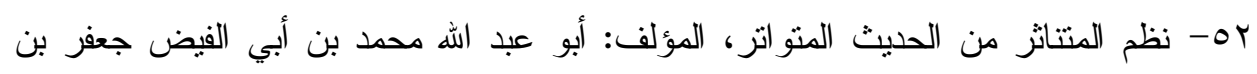

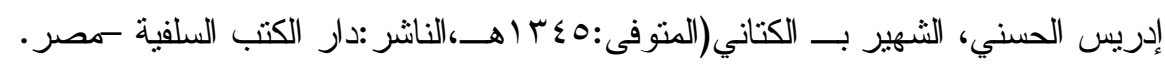
ror- النكت على مقدمة ابن الصلاح، المؤلف: محمد بن عبد الله بن بهادر الزركثي الثشافعي :لني

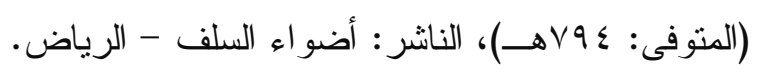

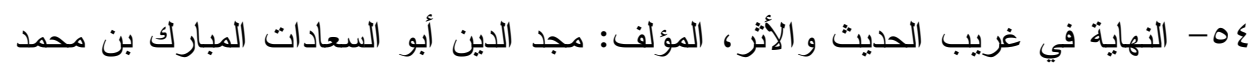
ابن الأثير (ت7 ـ 7هــ) ط: المكتبة العلمية بيروت.

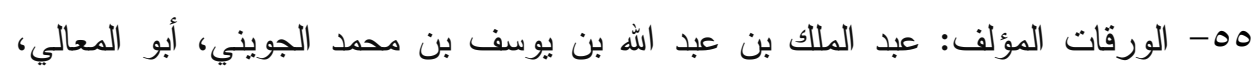

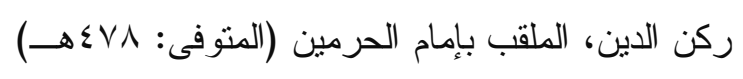

7ه- الوسيط في علوم ومصطلح الحديث المؤلف: محمد بن محمد بن سويلم أبو شُهبة النية (المتوفى: ب • (اهـ)، الناشر : دار الفكر العربي. 